This work is licensed under a Creative Commons Attribution 4.0 International License.

Ovaj rad dostupan je za upotrebu pod licencom Creative Commons Imenovanje 4.0 međunarodna.

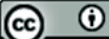

Zvonko PANDŽıĆ

Wirtschaftsgymnasium Tauberbischofsheim

Dr.-Ulrich-Straße 1

97941 Tauberbischofsheim

Deutschland

zvonko-pandzic@t-online.de
UDK 821.163.42.09 Marulić, M. DOI: https://doi.org/10.29162/ANAFORA.v6i1.1

Izvorni znanstveni članak

Original Research Article

Primljeno 22. veljače 2019.

Received: 22 February 2019

Prihvaćeno 18. ožujka 2019.

Accepted: 18 March 2019

\title{
MAGNIFICAT ANIMA MEA DOMINUM
}

\author{
Hrvatski prepjev i egzegeza Marka Marulića \\ Velle parum est; cupias ut re potiaris, oportet. \\ P. Ovidius Naso, Epistulae ex Ponto, 3,1,35
}

Stanislao Škunca, OFM alumno doctissimo sacrum

\section{Sažetak}

Autor u ovoj studiji nastavlja svoja istraživanja iz 2009. o izgubljenim djelima hrvatske proze koja je Marko Marulić (1450. - 1524.) sastavio za svoju sestru Biru (Elviru, Veru), o čemu piše on sam, ali i njegov bliski prijatelj Frane Božićević. Analizirana je egzegeza Magnificata iz Firentinskoga zbornika (Ashb. 1582) tako što je autor usporedno čitao tekst tog hrvatskog rukopisnog izlaganja iz Firence i odgovarajući tiskani tekst latinske Biblije (1489) iz privatne biblioteke Marka Marulića, na kojoj je on svojeručno bilježio rubne glose i minijaturne crteže. Utvrđeno je da autor egzegeze, rukopis potječe iz Splita, dijelom preuzima, prevodi i parafrazira komentare Nikole od Lyre koji su objavljeni usporedno - stih po stih - s latinskim tekstom Biblije koju 
je posjedovao i glosirao Marulić. Kako nijedan ini pisac iz Splita njegova doba nije posjedovao, a kamoli glosirao rečenu Bibliju, zaključeno je da je Marulić, uz brojne druge dokaze i indicije, i zbog te činjenice, autor spomenute egzegeze i Firentinskoga zbornika. Time je konačno verificirana dugo osporavana teza Carla Verdianija (1957) kojom je Maruliću atribuirano autorstvo tog zbornika. Tom je verifikacijom pogođen i čitav niz inih hrvatskih proznih rukopisa koje također valja pripisati autoru Marku Maruliću. S pogledom na skorašnju 500. obljetnicu smrti oca hrvatske književnosti (1524. - 2024.) autorovi nalazi stavljaju hrvatsku filologiju pred velike kritičko-izdavačke izazove.

Ključne riječi: Marko Marulić, egzegeza, Magnificat, Firentinski zbornik (Ashb. 1582), atribucija anonimnih hrvatskih kodeksa

\section{1. Što je to Magnificat?}

U Lukinu se evanđelju (Lk 1,39-56) čita da je Marija, nekoliko dana nakon što joj je anđeo Gabrijel navijestio Isusovo rođenje, pošla u gorje posjetiti svoju rodicu Elizabetu. Duhom Svetim nadahnuta Elizabeta pozdravlja i blagoslivlje Mariju i njezino dijete (»blagoslovljena ti među ženama, i blagoslovljen plod utrobe tvoje«) dočim Marija odgovara hvalospjevom koji slavi Boga (Lk 1,4655). Taj se hvalospjev prema prvom stihu u Vulgati zove Magnificat anima mea Dominum, a hrvatski Veliča duša moja Gospodina.

Magnificat nalazi svoj žanrovski, sadržajni i kompozicijski uzor u starozavjetnom hvalospjevu proročice Ane (1 Sam 2, 1-10), a preuzima doslovce ili neizravno i druge psalamske i proročke stihove. Počinje zahvalom Bogu za sve ono što je učinio za samu Mariju (46-49), potom se promatra opće Božje spasiteljsko djelo (50-53), naposljetku je riječ o milosti koju je Bog udijelio izabranom narodu (54-55) po obećanju koje je nekoć dao Abrahamu i potomcima njegovim. Milost koju Bog ukaza Mariji djelotovorna je za cijeli narod izraelski, pa time i za sav narod Božji u Crkvi.

Hvalospjev veliča spasiteljsko djelo Božje, njegov moćni zahvat u korist poniženih, malih i poniznih, dočim je opomena upućena oholima i bogatima koji sjede na prijestoljima ovoga svijeta. Iskustva ranijih spasonosnih djelovanja bude nadu i u buduća, odnosno postojana djela milosti Božje. Marijina poniznost (humilitas), dakle spremnost da prihvati svoju zadaću, postaje ključna krepost koju trebaju nasljedovati svi Kristovi i njezini štovatelji.

U četvrtu nedjelju Došašća čita se ulomak evanđelja o susretu Elizabete i Marije koji završava s prvom rečenicom Magnificata. Na blagdan Pohođenja 
Marijina (31. svibnja) i Uzašašća Blažene Djevice Marije u nebo (Velika Gospa, 15. kolovoza) u evenđelju se čita cijeli hvalospjev. Već oko 530. sveti je Benedikt u pravilu svoga reda (Sancti Benedicti Regula monasteriorum) propisao da za večernje službe (oficija) nakon psalama dolazi čitanje, što je u praksi prihvaćeno kao čitanje Magnificata. Isti izbor ima i Rimski časoslov pa cijela Crkva do danas - po teološki dosljednoj interpretaciji - zajedno s Majkom Gospodinovom svakodnevno hvali i slavi milostivoga Boga, bilo čitanjem bilo pjevanjem Magnificata.

S Rimskim časoslovom i gregorijanskim pjevanjem hvalospjev je proširen po cijeloj Europi i na svim jezicima, pa je tako ušao i u hrvatski oficij, bio on na crkveno-slavensko-glagoljaškom amalgamu ili pučkom jeziku, jer oba slijede Rimski časosolov. Već stoljećima ga svojim instrumentalnim i vokalnim kompozicijama šire najpoznatiji skladatelji i pjevači. Kako je Magnificat s velikim zanosom na njemački preveo i protumačio i sâm Martin Luther (Das Magnificat, verdeutscht und ausgelegt, 1521.), nije bilo zapreka da se hvalospjev proširi i po zemljama koje je zahvatila reformacija, inače vrlo suzdržana glede štovanja Bogorodice. Tako se i danas često izvodi i sluša peteroglasna kantata Magnificat Johanna Sebastiana Bacha iz 1723. (u Es-duru BWV 243a) i 1730. (u D-duru BWV 243), nastala u kasnobaroknom protestantskom Dresdenu. Magnificat je u svim svojim inačicama, tekstualnoj, glasovnoj i instrumentalnoj, de facto skanoniziran`, dakle ne samo od god. 325. i koncila u Niceji pa nadalje kao biblijski tekst Lukina evanđelja, nego i praktički - liturgijskim i paraliturgijskim - živim čitanjem, pjevanjem i sviranjem u kontinuitetu tijekom skoro dva tisućljeća, kao jedan od najpoznatijih i najljepših hvalospjeva svjetske himnografije.

\section{0 metodi istraživanja - Marula Marulom}

Marulićeva marijanska - autorska i prevedena - hrvatska poezija kao i teologija o Mariji pisana latinskim jezikom su poznate, ali je njegov Magnificat (Veliča duša ma) ostao na rubu zanimanja (slično i prepjev Te Deum laudamus), iako su mu i prepjev, još od Jagićeva izdanja (Marulić 1869: 213), i hrvatsko izlaganje (ekspozicija, egzegeza), već odavno (Verdiani 1973: 47-59, 119-148) bili objavljeni. Marulićevo je autorstvo cijeloga Života sv. Ivana Krstitelja, u kojemu se, u firentinskom rukopisu, dvaput interkaliran nalazi himan Veliča duša ma, u Vartalu također dvaput, jedanput tu u istovrsnom i međuovisnom Životu sv. Ivana Krstitelja, a drugi put unutar jedne druge pjesme, bilo potvrđeno od Verdianija (1957, 1973), kasnije od Tomasovića (1999: 257sl.) i, navlastito, od 
Parlova (2002). Oni su argumentirali suprotiva davnašnjim pokušajima (Malić 1976, Moguš 1976) da se ospori Marulićevo autorstvo Firentinskoga zbornika, a samim time i Marulićeva prepjeva Veliča duša ma i popratne ekspozicije na hrvatskom, tvrdeći da se nekim riječima iz toga zbornika Marulić u svome opusu nije koristio. Njihova je tvrdnja, koja je počivala na manjkavom uvidu u hrvatska djela Marulova, konačno falsificirana, a Verdianijeva višestruko verificirana (Pandžić 2009: 50-106), jer su, između ostaloga, ama baš sve riječi koje navodno nije poznavao Marulić, pronađene u njegovim hrvatskim djelima.

Ovdje propitujemo međuovisnost hrvatskih kodeksâ u kojima se nalaze prozni prijevod i sedam prijepisa dvanaesteračkog prepjeva hvalospjeva. Kako su pak ti kodeksi sadržajno i(li) ortografijski usko povezani ne samo međusobno nego i s inim splitskim kodeksima s početka 16. st., a skoro svi opet i s latinskim i talijanskim predlošcima (metatekstovima), to ćemo na primjeru Magnificata, odnosno Života sv. Ivana Krstitelja kao tekstualnog čvorišta rasprave, uznastojati produbiti i novim nalazima proširiti sinoptičko-kodikološku, filološku, a manjim dijelom i teološku analizu i argumentaciju o Marulićevoj izgubljenoj hrvatskoj prozi započetu prije desetak godina u knjizi Nepoznata proza Marka Marulića (Pandžić 2009).

I ovaj se put radi o temeljnim istraživanjima (Grundlagenforschung, basic research), dakle o daljnjem dokazivanju što je to uopće Marko Marulić na hrvatskom jeziku napisao, odnosno o proširenju paradigme hrvatska proza i poezija Marka Marulića. ${ }^{1} \mathrm{Na}$ taj se način trebaju stvoriti novi, uvelike prošireni temelji za buduća istraživanja i (pre)vrednovanja hrvatske književnosti, jezika, poetike, teologije i kulture uopće u doba europskog humanizma i hrvatske renesanse, a djelâ Marka Marulića i posebno. Kritika se teksta i proširenje opusa kategorijski, tj. po razini i predmetu istraživanja - što je to dakle određeni autor uopće napisao - a ne tek po izabranoj znanstvenoj metodi (metajeziku), razlikuje od metode kojoj je cilj pojasniti kako je isti autor svoja već odavno poznata djela sastavljao, primjerice, kojim se tipom dvanaesterca koristio ili na koji način danas treba njegova djela pisana neujednačenim latiničnim slovopisom (orto)grafijski i fonematski transponirati u suvremenu gajicu. Naš pristup ne osporava takav način istraživanja, dapače, književnoteorijski i lingvistički on je posve opravdan, barem dok je u refleksiji određeneog istraživača prisutna svijest da to nije jedina metoda književnopovijesnog i lingvističkog istraživanja, te da još uvijek ni izbliza nije

Iscrpniju kodikološku, filološku i teološku analizu svih za Marulićevo djelo relevantnih hrvatskih kodeksa i inkunabula koje je na latinskom glosirao, ponudit će naša knjiga: Tajna djela Marka Marulića. Drugi plov suprot kulturi zaborava u hrvatskoj humanistici (radni naslov). 
zaokružen ni opus ni korpus ni kanon, zanemarimo načas činjenicu da se ta tri književnoteorijska pojma ponekad koriste arbitrarno i(li) promiscue, hrvatskih djela Marka Marulića. Ipak, ovdje taj pristup ostavljamo po strani, interpretacija dolazi nakon atribucije, i, po mogućnosti, kritičkog izdanja teksta.

Drugim riječima, kako je to ispravno prosudio Parlov (2002: 444) prilažući nove dokaze (uz Verdiani 1957, 1973) za Marulićevo autorstvo Života sv. Ivana Krstitelja, kritika (povijest nastanka, formacija) i atribucija teksta moraju počivati na već odavno potvrđenim metodološkim kriterijima, kakvi su oni nutarnji - jezični, intratekstualno-stilistički i sadržajni - sravnjeni naravno i s vanjskim (intertekstualnim) literarnim i teološkim uzorima i predlošcima pisca:

»U procesu atribucije nekoga djela držimo da nije dostatna sama jezična analiza (zbog faktora prepisivača!) niti inače nesigurni metrički kriteriji. Njima je potrebno dodati kriterije okrenute nutarnjoj kritici teksta, po kojima se utvrđuje stil autora, njegov način izražavanja i misaona osobitost, a što se utvrđuje preko analize sadržaja (duhovnog, teološkog, književnog itd.) dotičnog spisa. Najsigurniji put u ovakvu pristupu druga su djela istog autora, odnosno tumačenje jednog autora njegovim vlastitim djelima.«

Zapravo, tu je nutarnju sinoptičku metodu biblijska filologija već od trećeg kršćanskog stoljeća (Origen), nešto kasnije i sv. Jeronim, koristila za konačno oblikovanje i izlaganje biblijskog kanona, slično i kasnoantička hermeneu-

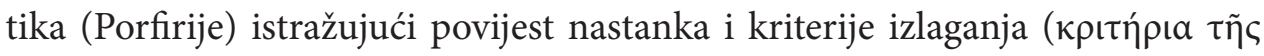

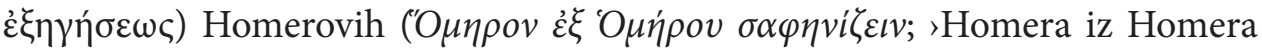
objasniti`), Platonovih (`Platonem ex Platone`) i Aristotelovih djela. Ovdje je zanimljivo navesti, pomaže nam razumjeti hermeneutiku formacije i interpretacije povijesnih tekstova uopće, pa tako i Marulićevih, ${ }^{2}$ da je hrvatski filozof i humanist, najpoznatiji tumač Platonove i Aristotelove filozofije u drugoj polovici u 16. st., Crešanin Frane Petrić (1529. - 1597.), razvio metodu po kojoj se konačno moglo razlučiti prava Aristotelova djela od njegovih spuria. Oslanjajući se i na antičke komentare koje je otkrio na Cipru, svojom je analizom reatribuirao nekoliko djela koja su bila pripisivana Aristotelu, a doveo je u pitanje i njegovu Metafiziku kao jedinstveno djelo. Nalazi su mu dijelom potvrđeni tek

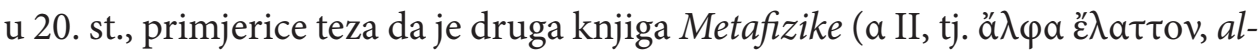

I Glavičić (1993: 15) je za rekonstrukciju spornih mjesta u Marulićevoj latinskoj Davidias ustvrdio da je najbolja metoda usporedba sa sličnim mjestima, tj. tumačiti »Marulića Marulićem«. 
pha minor, manja alfa) tu zapravo strano tijelo, što je verificirao veliki njemački filolog Wolfgang Jaeger (1888. - 1961.). ${ }^{3}$

U načelu ista ta, dvostruka metoda istraživanja - duplex theoria - tekstualno-kritičko filološko kolacioniranje jezično-stilističkih osobina (ne)datiranih hrvatskih kodeksa kao i onih djela koja su sigurno Marulićeva (`Marula Marulom`) uz analizu povijesnih svjedočanstava o njima, te, s druge strane, kodikološka, sadržajno-teološka i poetološka intratekstualna i intertekstualna usporedba njegovih rukopisa s citiranim predlošcima, vrijedi naravno ne samo za hrvatska nego i za latinska djela Marulova. Potonja su, srećom, skoro sva u međuvremenu tiskom objavljena, ${ }^{4}$ uz latinski tekst dodan je hrvatski prijevod, velikim marom, prije svih, Branimira Glavičića (1926. - 2010.). Bilo je to moguće jer su pod autorovim imenom stoljećima čuvana po raznim europskim knjižnicama, uredno katalogizirana i u publikacijama izrijekom opisana kao Marulićeva, uključujući tu, između ostalih, Davidias, Vita divi Hieronymi i tzv. Glasgowske epigrame, koje su katalogizirali i Maruliću još davno atribuirali Škoti Young John i Henderson Aitken (1908: 270-271).

Ipak, barem dva pitanja i glede Marulova latinskog opusa još uvijek traže odgovor, odnosno izdavački napor, što ovdje tek spominjem: a) je li on doista i na latinskom jeziku napisao djelo De imitatione Christi, ili je tu riječ o njegovu hrvatskom prijevodu iz 1500. istoimenog glasovitog djela Tome Kempenca, a koji je u međuvremenu dvaput tiskan u cjelovitom obliku (Marulić 1989a, 1989b);

Petrić je donio brojne kriterije za kritičko propitivanje autorstva Aristotelova opusa koje je potom sveo na dva za atribuciju teksta ključna suprakriterija: »1. durch einen textkritisch-philologischen Vergleich intrastruktureller stilistischer Merkmale der griechischen Sprache mit ältesten Interpretamenten und Zeugnissen über das Corpus Aristotelicum [...]. 2. durch einen philosophisch-inhaltlichen Vergleich, der die >reine Lehre des Aristoteles [...] intrastrukturell im Sinne der Selbstauslegung [...] und interstrukturell über die zu erschließende Interpretationstradition offenlegen sollte« (Pandžić 1999: XXV).

$4 \quad$ Nakon što je ovaj tekst bio predan u tisak u knjižnici Franjevačkog samostana u Splitu na Poljudu otkrio sam tridesetak tomova (inkunabula i knjiga tiskanih do 1522.) iz Marulićeve privatne knjižnice (naslova je manje jer su neka djela višetomna), koje je on svojeručno komentirao i sitnoslikarski ukrašavao. Njegovi rubni komentari na Ciceronovoj De inventione i na tzv. Rhetorica ad Herennium, inkunabula je iz 1483., imaju npr. oko tisuću što duljih što kraćih bilježaka uz brojne minijature. Samo za te glossae nužno je planirati jedan novi svezak u sabranim mu djelima. I komentari na inim inkunabulama i ranim tiskovinama s početka 16. st. tražit će, po prvoj procjeni, daljnje sveske u latinskom dijelu Marulovih sabranih djela. O brojnim hrvatskim rukopisima, koje sam prije desetak godina pronašao i(li) njemu atribuirao, govori se u 7. poglavlju ove rasprave. Već je sada razvidno da će se u Marulovim sabranim djelima jednoga dana naći, već prema opsegu određenog rukopisa, i desetak novih hrvatskih svezaka. Tekstovi su to s (bez)brojnim novotvorenicama u leksiku i inovacijama u stilistici, istinski početci hrvatske književnosti na narodnom jeziku, i danas vrlo dobre razumljivosti i - navlastito - inovativne jezične stilizacije (volgare illustre). Sve u svemu, Marulovo književno djelo postupno dobiva posve novi opseg i novu, daleko precizniju, vizuru. 
b) kada će usporedno biti izdane tri njegove hrvatske vitae (usp. Pandžić 2009: 138-141), sv. Dujma, sv. Staša i prijenosa njihovih tjelesa iz Solina u Split grad (rk. 589, str. 323-352, Knjižnica Male braće u Dubrovniku), s latinskim, opet najvjerojatnije Marulovim, inačicama istih vitâ koje je objavio Farlati (1751). Kao deziderat ostaje i usporedno hrvatsko-latinsko izdanje Marulićeva Života sv. Jerolima, iako je ta vita ponaosob objavljena u obje inačice.

Za razliku od latinskih mu tiskanih djela koja su bila čitana i prevođena po cijeloj Europi i šire, bila su dakle za ono doba globalnog karaktera, Marulićeva hrvatska rukopisna djela i prijevodi, koja je sastavio uglavnom za svoju dragu sestru Biru, bila su regionalnog karaktera, tj. rado čitana, prepisivana i preseljavana, na tisak na hrvatskom zbog skupoće nije se ni pomišljalo, uglavnom po ženskim samostanima u Splitu, Trogiru i Zadru. Sačuvani su nam stoga često samo prijepisi, a i ti, međutim, zbog oštećenja papira slijedom stalnog čitanja, uglavnom bez naslovnice i kolofona, zbog čega je atribucija hrvatskih Marulovih djela, u usporedbi s latinskima, daleko složenija zadaća interdisciplinarne filologije i kodikologije. Ipak, sačuvani su i nedavno pronađeni i ini splitski hrvatski rukopisi datirani još za života Marulova, pa će upravo ti biti prvi kodikološki i filološki orijentir, odnosno korektiv sljedećih razmišljanja o njegovim `tajnim`, odnosno `zatajenim` hrvatskim djelima.

Pritom valja naglasiti da je Marulić desetljećima imao i svoj vlastiti skriptorij, tj. pisare koji su njegove tekstove prepisivali učisto (Pandžić 2009: 59), bilo već zgotovljene radove s pisanoga predloška, bilo po njegovu diktatu, kako su to već pretpostavljali Verdiani i Hamm. Marulić naime u pismu od 4. travnja 1507. bilježniku Jakovu Grosolariju, svom mletačkom agentu i prijatelju, zbori kako je djelo Vita beati Hieronymi dao prepisati prije nego što mu ga pošalje u Mletke (Milošević 1992: 50): »Interim beati Hieronymi vitam, his diebus a nobis editam tibi mittam, cum primum ab illis, quibus concessi transcribendam, habere potero«. Lučin (2017: 10, bilj. 16) je pokušao ispraviti Glavičićev prijevod »concessi transcribendam «, kako ne bi bilo » dao na prepisivanjeく, što bi se moglo shvatiti kao nalog ili narudžba, nego >ustupio na prijepis««. Ustupio ili dao, svejedno, nakana je Marulićeva posve jasna, prije nego što rukopis pošalje u Mletke želio je da mu ostane barem jedan primjerak. Grosolari je u svakom slučaju dobio prijepis koji su načinili Markovi pisari, jer je sačuvan Marulićev autograf pisan na pergameni (usp. Novaković 1994), a taj je kasnije dospio u Englesku. Kako Marulić »spominje više prepisivača», Lučin smatra »da se ovdje nije mislilo na podjelu posla zbog opsežnosti«. I nije. Marulić je usput samo dao do znanja da 
njegovi pisari trebaju vremena za prepisati Vita divi Hieronymi prije nego što on rukopis spremi u Mletke. Očito je pisare imao i inače i već odavno, a ne tek ad hoc za tu jednu zgodu iz 1507. To je utoliko vjerojatnije jer se dugo bavio i pravnim poslovima kao sudac, no vodio je, danas bi se reklo, i odvjetničku i(li) bilježničku pisarnicu, Grosolari mu je bio partner u Mletcima.

Da je Marulić doista imao više pisara, barem od 80-ih godina quattrocenta, posvjedočio je i Bartolomeo Merula iz Mantove, službujući učitelj gramatike u Splitu (1478. - 1489.), naslijedivši na tom mjestu Marulićeva učitelja Tidea Acciranija (usp. Parenti 1978: 271-283, Košuta 1992: 69sl.). Merula je u to doba sastavio nekoliko epigrama, sačuvani su u jednom firentinskom kodeksu ( $M a$ gliab. VII, 1183, ff. $\left.122^{\mathrm{v}}-136^{\mathrm{v}}\right)$, posvetio ih je pojedinim uglednim Splićanima i zidinama grada Splita (De muro Spalatinae Urbis), tako jedan (f. $127^{v}$ ) Ad Marcum Marulum, a drugi, već na sljedećem listu (f. 128 $8^{\mathrm{rv}}$ ), Ad scribas domini Marci (Pisarima gospodina Marka). Prvi je objavio Košuta (1992: 70), u njemu se Marulić slavi kao Bogom nadahnuti pjesnik (Castalidum cultor), drugi ovdje donosim prijepisom i preslikom: ${ }^{5}$

\section{Ad scribas domini Marci}

Dyrceos memini latices haurire solebam,

Aut hedera aut querna cingere fronde comas.

Nil mihi Musa dabat nil pleb<e $>$ s sordida semper,

Paupertas aderat tergeminumque sophos.

Cerea uelabat miserum uel trita lacerna,

Que poterat tauri cornua panda pati.

Nunc igitur steriles Musasque lyramque relinquo

Et scribam causas quidquid agatque forum.

Vos modo iam patres precibus faueatis honestis,

Audiat o uestras sic Deus ipse preces.

Pri čitanju nekih riječi epigrama pomogao mi je Bratislav Lučin, voditelj Marulaniuma u Splitu, zacijelo najbolji poznavatelj `kanoniziranog`Marulićeva opusa u Hrvatskoj. Nadam se da će dati svoj obol i u analizi novotkrivenih, ovdje temetiziranih, Marulovih hrvatskih djela, kao i onih latinskih (usp. prethodnu bilješku). U filologiji hrvatskoga latiniteta, u pripadajućoj latinskoj metrici, ali i u poznavanju geneze starije hrvatske metrike, po mom skromnom sudu, nema mu premca u današnjoj Hrvatskoj. Ovo i zbog toga jer je hrvatska poezija od samih početaka bila pod utjecajem latinske, a Marulićeve inovacije u metru svoje izvorište također imaju u latinskoj i talijanskoj poeziji. Kako je Lučin duboko prodro i u jednu i u drugu književnost i poeziju, a hrvatski kroatisti koji se danas bave Marulićevim djelom latinski jezik, iznimkama čast, uglavnom ne poznaju, njemu je već odavno pripala zadaća, da, uz latinska, priprema i sva ozbiljnija izdanja Marulićevih hrvatskih djela. 
U maniri Marcijalovih epigrama, a uz asocijacije na Vergilija i Horacija, autor bilježi samorefleksiju svoga pjesnikovanja. Ranije je slijedio muze, bršljanovim i hrastovim vijencima kitio kose, no ništa mu nije dao `trostruki aplauz‘, tj. muza, prljavog puka i općeg siromaštva. Sada napušta jalova posla, muze i liru, pa će pisati o tomu što se bude radilo na sudu. Njih pak, Markove pisare, u onoj mjeri u kojoj se posvete hvalevrijednim molitvama (razmatranjima), čut će sam Bog.
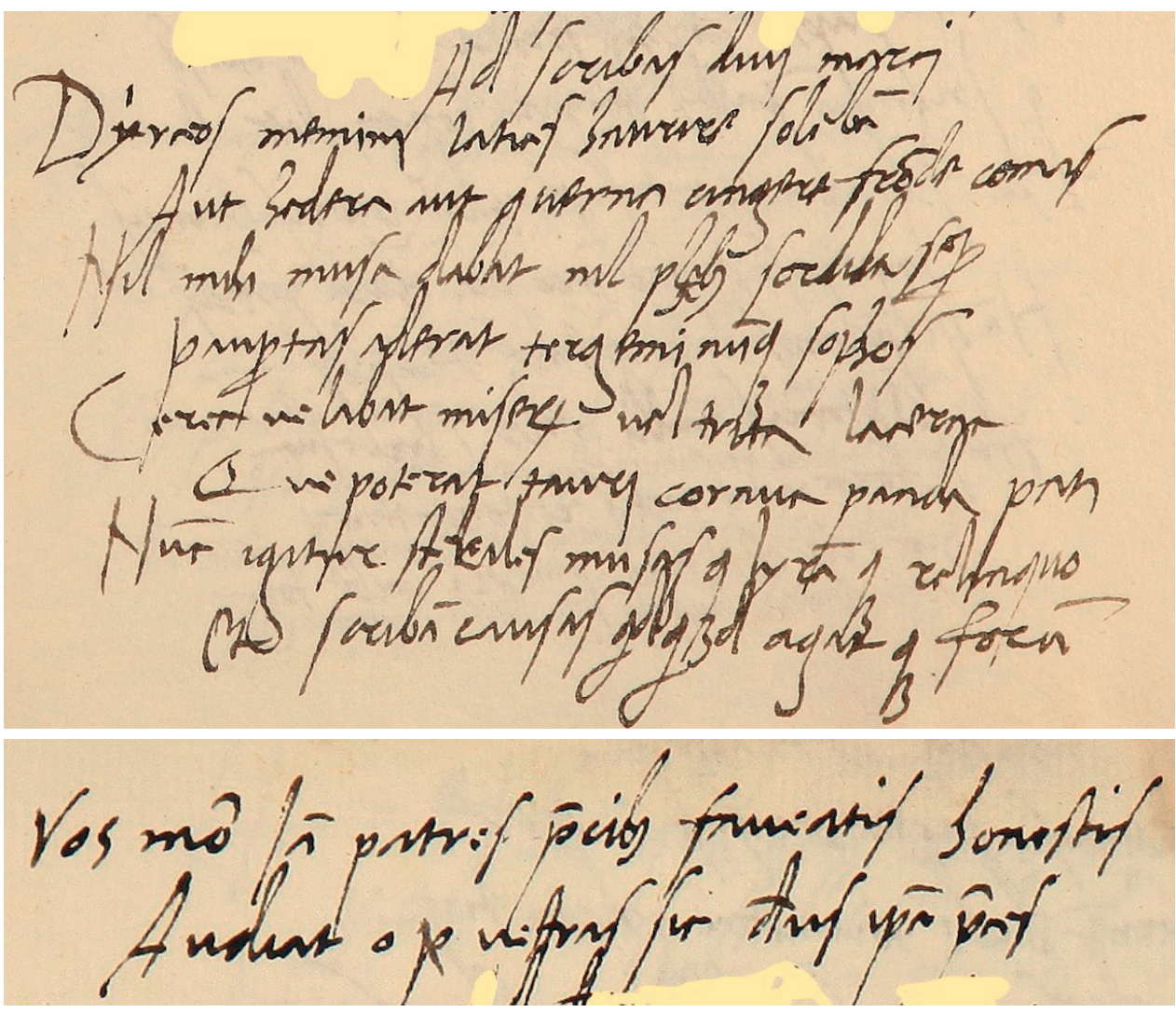

Sl. 1. Bartolomeo Merula Pisarima gospodina Marka (Magliab. VII, 1183, f. 122 ${ }^{\text {rv }}$ )

Merula povezuje sudbinu svoju i Markovih pisara. Sam je nakon muza, lire i ispraznog aplauza odlučio mijenjati zanimanje pa će sada pisati o parnicama na sudu, dočim se pisari posvećuju meditacijama na slavu otaca, tj. Markovim djelima. Kako znamo da je Merula u prethodnom epigramu Marulića nazvao pjesnikom kastalidskih muza (Castalidum cultor), jasno je da i njegovi pisari, prionivši pobožnim razmatranjima, mogu očekivati da će ih uslišiti sam Bog. U 
našem kontekstu jedna je vijest iz Merulina epigrama posebno važna. Marulić je u 80-im godinama 15. st. pisao poeziju, a služili su mu njegovi pisari. Stoga pitanje pisoruka (autografa) neće biti odlučujuće za konačnu atribuciju nekog hrvatskog kodeksa Marku Maruliću, prijepis je uvijek mogao načiniti i neki od pisara. O njoj će suditi ne jedan, nego nekoliko inih kriterija interdisciplinarne filologije uz pomoć kodikologije i paleografije. ${ }^{6}$

\section{Inačice Marulićeva Magnificata}

Vidjeli smo da je po Rimskom časoslovu (brevijaru) nakon psalama večernje službe slijedilo čitanje ili pjevanje Magnificata iz Evanđelja po Luki. Marulić je sastavljajući Oficij blažene dive Marije, najvjerojatnije za svoju sestru Biru jer su svi dijelovi u rodovski obilježenim fleksijama prilagođeni ženskoj osobi, to čitanje preveo u prozi; lijevo je Marulićev prijevod, a desno, usporedbe radi, prijevod iz starijeg Vatikanskog molitvenika (oba prema Fancev 1934: 96 i 28):?

\begin{tabular}{|c|c|}
\hline $\begin{array}{l}\text { Veliča duša moja gospodina: i uzradova } \\
\text { se duh moj u bogu spasu momu. Jer po- } \\
\text { gleda na humilenstvo rabe svoje: evo bo } \\
\text { od sada blaženu će mene zvati svi na- } \\
\text { rodi. Jer mi velika učini ki moguć jest: } \\
\text { i sveto ime ńegovo. I milosrdje ńegovo } \\
\text { od naroda do naroda bojućim se ńega. } \\
\text { Postavi moć u mišcu svoju: rastrka oho- } \\
\text { lih pametju srca ńih. Shiti mogućih s } \\
\text { pristolja, i uzvisi poniženih. Lačnih na- } \\
\text { puni dobra: a bogatih ostavi tašćih. Pri- } \\
\text { ja Izraela slugu svoga, spomenu se od } \\
\text { milosrdja. Kako je obitao otcem našim, } \\
\text { Abramu i simenu ńegovu u vike. }\end{array}$ & $\begin{array}{l}\text { Usuelica dufca moia gofpoda. I-ufradoua-fe } \\
\text { dux moi o-bogu fpafiteglu momu. Iere } \\
\text { prifri na-fmirenie rabe fuoie. ouo odfele } \\
\text { blafgenu-me gouore fui narodi. Iere ucini } \\
\text { meni uelicha. coi ufmofgan ieft i fueto ime } \\
\text { gnegouo. I miloft gnegoua od-roda do-ro- } \\
\text { da boiechi-fe gnega. Stuori criepoft u-mifci } \\
\text { fuoioi rafparfca ohole mifalju farça suoga. } \\
\text { Snimi moguche f-priftolia i-ufduife fmirne. } \\
\text { Lacne napuni blaga a-bogate otpufti tafti. } \\
\text { primi ifdraela dieteta fuoga fpomenuo-fe } \\
\text { ieft od-milofti suoie. Cacho gouorio ieft fo- } \\
\text { oççi nafciemi abramu i-fiemenu gnegouu } \\
\text { deri do-uiecha. }\end{array}$ \\
\hline
\end{tabular}

$6 \quad$ U idealnom bi slučaju dostupnost svih hrvatskih kodeksa na svemreži (e-codices) po uzoru na švicarski projekt http://www.e-codices.unifr.ch/de znatno olakšala istraživanje i ovdje diskutiranih ranonovovjekovih rukopisa. Kao prioritet valjalo bi na taj način učiniti pristupačnim legat Ivana Kukuljevića Sakcinskog iz Arhiva HAZU-a. O proširenim mogućnostima kodikologije i paleografije u digitalno doba usp. Rehlein et al. eds. 2009. Međutim, autopsiju rukopisâ in situ digitalna pomagala ne zamjenjuju nego samo olakšavaju.

7 Ovdje bi se moglo donijeti i dvije ine pučkojezične varijante, s kojima je Marulić mogao izravno ili neizravno doći u kontakt (Fancev 1934: 241, 268/Gianelli), tj. onu iz Dubrovačkog psaltira i onu iz Najstarijeg štampanog hrvatskog molitvenika. Kako je već na prvi pogled očito da one imaju daleko više zajedničkih crta međusobno is Vatikanskim molitvenikom negoli s inačicom iz Oficija blažene dive Marije Marka Marulića, za našu argumentaciju ovdje nisu nužne. 
Malić $(1999,2003,2004)$ je čak nekoliko puta pokušavala osporiti Marulićevo autorstvo tog oficija (I a 5, Arhiv HAZU), što je inače već bio potvrdio i glavne dijelove objavio Fancev $(1933,1934)$, premda ni ona nije osporavala da su prepjevani himni oficija njegovi, poznati inače kao Marulićevi iz vremenski kasnijeg Lucićeva Vartala. Usto, taj oficij, prepisan je u prvoj polovici 16. st., počinje s epigramom koji ga izrijekom pripisuje Maruliću (Fancev 1933: 69; 1934: 79):

Marul tumači toj na slavu gospoje,

Zemļa i nebo koj svagdan hvale poje.

Molite za ńega, ke koli čtite toj,

da bog s truda sega stavi ga u pokoj. Amen.

U Oficiju opažamo i jedinstvenu lingvističku pojavu, na nju se Malić uopće ne osvrće, a ta pojava Marulovo autorstvo cijeloga teksta samo potvrđuje, tj. i inih dijelova, a ne samo nesporno njegovih prepjevâ himana. I u proznom prijevodu i u prepjevu Magnificata, očito se radi o jednom autoru, uočavamo naime istu lingvističku pojavu koju u ono doba u toj čestoti susrećemo, koliko imam pregleda, isključivo u Marulićevim hrvatskim djelima. Riječ je o kategoriji produševljenosti (živosti) muških imenica ne samo u jednini, to je inače redovna pojava u hrvatskome jeziku, nego i u množini (usp. sve podvučene dočetke gen. pl.), što dubrovački štokavski oficiji i hrvatski književni jezik nemaju, pa ni Marulić ni bilo tko drugi tu lingvističku pojavnost nije mogao preuzeti iz dubrovačkih ili inih oficija (tako Malić 2004) koji ju ne poznaju, nego je to očito njegov lingvistički zahvat.

Ta se kategorija u slavenskim jezicima razvijala postupno, što je u nominalnoj fleksiji dovelo do zamjene akuzativa genitivom, izvorno samo u jednini muških imenica. Objekt radnje stavljao se u genitiv jednine umjesto u akuzativ kako bi ga se moglo razlučiti od nominativa, tj. subjekta. Akuzativ u staroslavenskom ostaje kod ssvoj< (poszla rabr svojb) i iza prijedloga jer nema objekta s rekcijom nominativa (věrujg vo bogr). Daljni je korak učinjen kada su i feminina mogla biti stavljena u genitiv ako stoje pored masculina (lûbiti otbca i matere), pa čak i neutra ako se odnose na agentne osobe (gen. sg. slova). Međutim, proširenje kategorije produševljenosti na množinu, kao što je to slučaj u ruskom, poljskom i gornjolužičkom jeziku, današnji hrvatski književni jezik ne poznaje, stoga je Marulićev prijevod blizak prijevodima na te jezike (ovdje donosim Lk 1, 51-53 
interlinearno: 1. hrvatski suvremeni, 2. Marulićev prozni, 3. ruski i 4. poljski prijevod):

Junačko djelo izvede mišicom svojom:

Postavi moć u mišcu svoju:

Явил силу мышцы Своей:

Okazał moc ramienem swoim:

rasprši one koji su oholi u misli srca svoga;

rastrka oholih pametju srca ńih;

рассеял надменных помышлениями сердца $\underline{\text { иx; }}$

rozproszył pysznych z zamysłów ịch serc;

zbaci s prijestolja vladare, a uzvisi neznatne;

Shiti mogućih s pristolja, i uzvisi poniženih;

Низложил сильных с престолов и вознес смиренных;

Strącił władców z tronów, a wywyższył poniżonych;

Gladne zasiti dobrima, a bogataše otpusti praznih ruku.

Lačnih napuni dobra: a bogatih ostavi tašćih.

Алчущих исполнил благ, а богатящихся отпустил ни с чем.

Głodnych nasyca dobrami, a bogatych z niczym odprawia.

Produševljenost muških imenica i u množini poznaje međutim čakavski dijalekt, pa tu kategoriju možemo načelno svrstati u čakavizme. Kod Marulića je ona relativno česta i upadljiva pojava, dakle ne samo u ovdje citiranom Magnificatu, što prije može upućivati na njegovu vlastitu književnu stilizaciju. Stariji molitvenici i oficiji naime, pa i oni glagoljski, produševljenost u prijevodima ovoga ulomka, koliko sam to uspio provjeriti, izgleda ne poznaju. Stoga mu se redakciju Magnificata, tj. činjenicu da je na svoj način preradio neki njemu možda poznati raniji prozni prijevod hvalospjeva, pokorničkih psalama i litanija, svi himni su isključivo njegov prepjev, kao i autorstvo cijeloga Oficija blažene dive Marije, i zbog te činjenice, ne može osporiti (falsificirati). ${ }^{8}$ 
Što se pak tiče ponegdje predmnijevanog općeg glagoljskog utjecaja na Marulićevu prozu i poeziju, tu se od doba Kukuljevića i Jagića u spoznaji nije ništa bitno izmijenilo, on nastoji pisati općerazumljivim jezikom svoga naroda, tj. uz svjestan odmak od pisanja na glagoljskom jezičnom amalgamu. ${ }^{9}$ Jezik kojim piše, uza sve pogrješke kasnijih prepisivača, stilistički je (sintaktički) prepoznatljiv, rječnik je pročišćen, biran s purističkim nabojem uz mnoštvo kalkiranih novotvorenica i kontaktnih sinonima, ${ }^{10} \mathrm{i}$ daleko je najbogatiji za to doba razvoja hrvatske pučkojezične pismenosti, a ima tek pregledan broj romanskih spalatizama. Ako izuzmemo metrički uvjetovane poteškoće kod čitanja njegove dvanaesteračke poezije, jezik mu je - unatoč čakavskom supstratu - interdijalektno razumljiv, i priprostom puku njegova vremena i nama danas. Navlastito se to odnosi na njegove prozne hrvatske tekstove. Razumljivost je i bila Marulova nakana kada se oslonio na Danteov ideal jezika prema De vulgari eloquentia, odnosno na analogni jezični ideal hrvatskoga >volgare illustre «. Konačno, samo takvim jezikom složena mogla su biti čitana (lectio divina), razumljena i prikazivana njegova prozna, epska, dramska i ina poetska pobožna djela, a to mu je i bila svrha pisanja na hrvatskome jeziku.

Za usporedbu gornjeg Marulićeva prijevoda Magnificata s glagoljskom tradicijom, odnosno u svrhu kontrole naše teze, donosimo i glagoljsku inačicu (uz transliteraciju) istog hvalospjeva iz tzv. Akademijina brevijara (Šimić 2014: f. $38^{\mathrm{bc}}$ ) koja, međutim, uz brojne ine razlike, ne poznaje kategoriju produševljenosti u množini.

u obje inačice ovdje, istovrsne dočetke gen. pl. (podvučeno), tj. onakve kakve ima Marulićevo i prozno i prepjevano Veliča duša ma. Štrkalj Despot (2011: 55) je i bez toga ustvrdila da je Malić "pokazala da taj rukopis nije Marulićev«. Međutim, već je Fancev (1933) znao da to nije pisoruk (autograf) Marka Marulića, o tome dakle nije ni bilo spora jer je oficij prepisao neki pisar, ali uopće nije sumnjao u autorsko i redaktorsko djelo Marulovo. Da Oficij blažene dive Marije nije djelo Marka Marulića Malić je, dakle, samo kazala, ali to nije ni pokazala ni dokazala.

$9 \quad$ Ne znači to da on glagoljsku slavensku liturgijsku pismenost nije poznavao, dapače, sigurno mu je bila poznata i na glagoljici i na hrvatskoj ćirilici jer je na latinski preveo i Regum Dalmatiae atque Croatiae gesta, djelo pronađeno u Poljicima. Međutim, pišući hrvatski on svjesno nije slijedio tu tradiciju nego onu pučkojezičnu kako bi ga svi razumjeli, što posebno naglašava u posveti Judite. Napisao je i jednu danas izgubljenu raspravicu (trattadello) na talijanskom o napadajima nevjernika na kršćane da se tiska kako bi ju svi u Mlecima razumjeli (Milošević 1992: 34):»[...] scritto è in sermon vulgare, aciò chadauno possa intender «. 


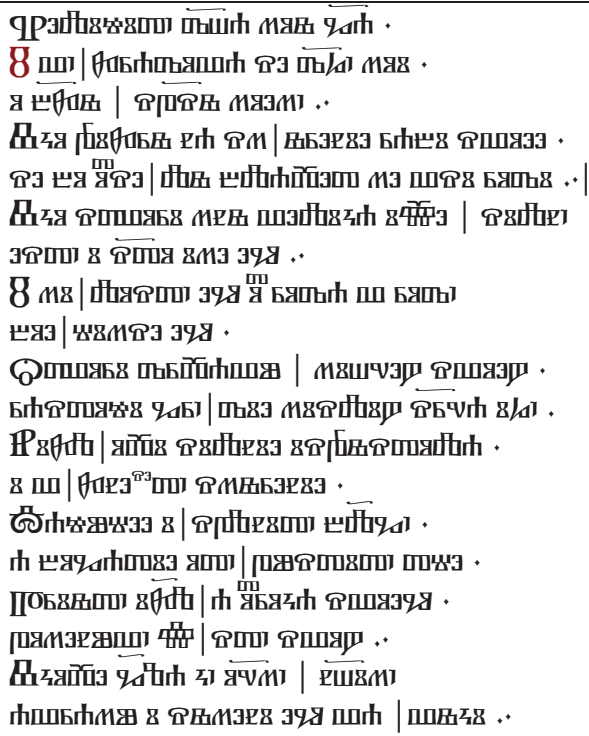

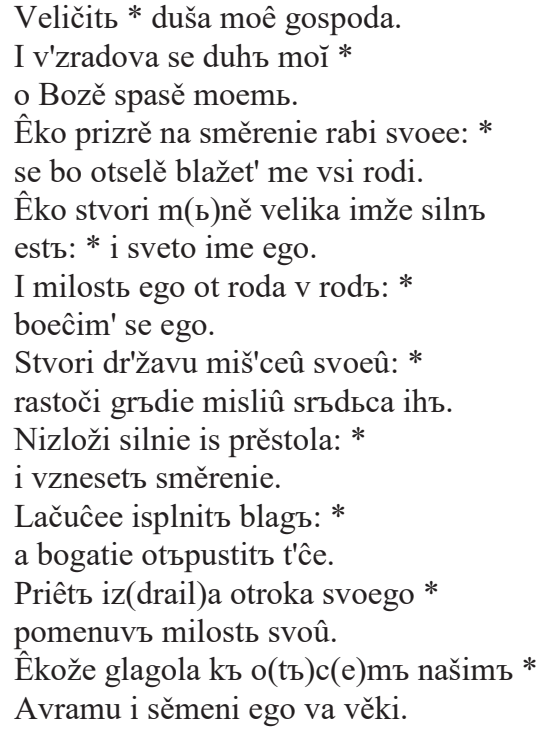

Osim proznog prijevoda Marulić je sastavio i "prekrasnu stihovanu transpoziciju Magnificata (Verdiani 1973: 51), koja je sačuvana u čak sedam prijepisa i svi se uglavnom dobro slažu: dva su u Životu sv. Ivana Krstitelja iz Firentinskog zbornika, dva su u Vartalu (IV a 31) redaktora Petra Lucića (1990), od kojih je jedna tu unesena u Život blaženoga i svetoga Ivana Krstitelja (f. 256 v), a druga je interkalirana u pjesmu Slavna gospoja zača Isusa (f. $280^{\mathrm{r}}-283^{\mathrm{v}}$ ). Nalazimo je i u Osorsko-hvarskoj pjesmarici (I a 62, f. $25^{\text {rv }}$ ) unutar pjesme De as $[s]$ um [p]tione Domin $[a]$ e, jednom u R 6634 (f. $16^{v}$ ) pod naslovom Magnificat. Zapisana je i u pjesmi Od uzvišen'ja Gospina u rukopisu I b $\mathbf{8 3}$ (f. 300-303 ${ }^{\mathrm{r}}$ ), tj. u Lulićevu zborniku. Neke inačice, tako mlađa iz Vartala (f. $283^{\mathrm{v}}$ ), imaju završni dvostih koji nema podlogu u Lukinu evanđelju, što je, kao molitveni završetak, dodatak nekog prepisivača. ${ }^{11}$ Izvorno je prepjev bio bez posljednjeg dvostiha, tj. dok hvalospjev kasnije nije preuzet u molitvenike i oficije (inčije Kolumbić u: Lucić 1990: 799sl.).

Ocu i sinu huala i duhu sfetomu,

do chonca od pocala trim bogu iednomu. (I a 62, f. $25^{\text {rv }}$ )

Otçu sinom huala // i duhu sfetomu,

do chonça od poçala // tri bogu iednomu. (R 6634/ No 21, f. 16

Ocu, Sinu hvala i Duhu Svetomu,

Do konca od počala, ter Bogu jednomu! （Lucić 1990: 500) 
Ovdje usporedno donosim dva najstarija prijepisa Magnificata iz dva Života sv. Ivana Krstitelja, dodajem i oba preslika (sl. 2 i sl. 3), koji se inače vrlo dobro sadržajno slažu, pa se mora zaključiti da je inačicu iz Vartala pisar Firentinskog zbornika ili preuzeo ili su obje imale zajednički stariji predložak, kako je o tome već i Verdiani argumentirao. Lijevo je inačica prema najstarijem dijelu Vartala iz pisoruka Marka Marulića (IV a 31, f. 256 v), a desno ona integralna iz Firentinskog zbornika (Ashb. 1582, f. 12 ). Drugu, u ekspoziciju Magnificata interlinearno kaliranu inačicu iz tog zbornika, donosimo u sljedećem poglavlju.

\section{Velẏca dusa ma // hualom gospodina uesela uasda sta // chad gnega pomina. Duch se usradoua // u bogu spasu mom chỳ nebesa schoua // ẏ zemglu sfacha s gnom. ${ }^{12}$}

Jer choga uisẏne // misal ne mose sech posry் na nẏzine // rabe se gorý stech. Chy் to budu znaty் // sýnouý od zene blazeny் budu zuaty் // od sad euo mene. Meni bo uelicha // stuorẏ chỷe moguch chomu nẏ prilicha // toliko ẏe slouuch. Milosardy்e suoýe // od roda do roda suẏm chi ga se boẏe // dauat mu ie goda. Sfarseno mogustuo // huumichýu sfu sagna a sardach oholstuo // dostogno rasagna. S pristolýa usuisenich // potischỷe dolicha usuýsy் humilenich // uarch nebes goricha. Lachnẏch ter ubosich // u dobro postauy a bogatich mnosich // ýsprasníf ostauy். Israela prýa // slugu sfoga ý gnemu obẏtanẏa ẏsda // ýstinan u sfemu. Chacho rece nasim // on roditeglem sam abramu y் ostalẏm // da tỷe dat sebe nam.
Vesela $^{13}$ dussa ma $\bullet$ hualom gospodina uesela uasda sta $\bullet$ chad gnega pomina. Duh se uzradouua $\bullet$ u bogu spasu mom chi nebesa schouua $\bullet$ zemglu i suacha s gnom.

Jer choga uisinu $\bullet$ misal ne more seh Pozri na nizinu $\bullet$ rabe se gori steh. Chi to budu znatj $\bullet$ sinouue od xene Blasenu te zuatj $\bullet$ od sad euuo mene. Meni bo uelicha $\bullet$ stuori chi e moguh chomu ni prilicha $\bullet$ tolicho ye slouuh. Milosardye suoye $\bullet$ od roda do roda sfim chi ga se boỳe $\bullet$ dauat mu he goda. Sfarsseno moguhstuo • fmiscu suoyju sagna a sardac oholstuuo $\bullet$ dostoýno razagna. $\mathrm{S}$ pristolýa usuisen $\underline{\underline{h}} \cdot$ potishe dolicha usuissi umiglenih • sfarh nebes goricha. Laçnih ter ubosih • u dobra postauui a bogatih mnozih • isprasnif ostauuj. Israela pria $\bullet$ slugu suoga gnemu obehanẏa izda $\bullet$ istinan u suemu.

Chacho reçe nassim • roditeglem on sam abraamu i ostalim $\bullet$ da he dat sebe nam.

Slovopis oba rukopisa bit će tabelarno i sinkronijski uspoređen s (tipo) grafijom Judite i nekoliko drugih splitskih rukopisa s početka 16. st. u poglavlju

12 Usp. zadnji stih Marulićeve Judite: „Chi nebesa schova/ i sfacha ostala«.

13 Verdiani (1973: 52) ovo odstupanje od veliča objašnjava na uvjerljiv način: »[...] riječ vesela kojom u DL počinje prvi stih dopušta pretpostavku - vidjet ćemo kako to nije jedini slučaj - da se tu radi o rastresenu prepisivaču (jer na f. $9^{r}$, kojega je prvi distih posebno analiziran ima veliça), pa zbog toga, opet ponavljam, čitav DL moramo smatrati kopijom, ne uvijek vjernom kopijom [...] . 
7. Stoga ovdje nije nužno o tome raspravljati. Ortografiju Firentinskog zbornika već je opisao Verdiani (1973: 14-16), a umetka u Vartalu Mladenović (1959).

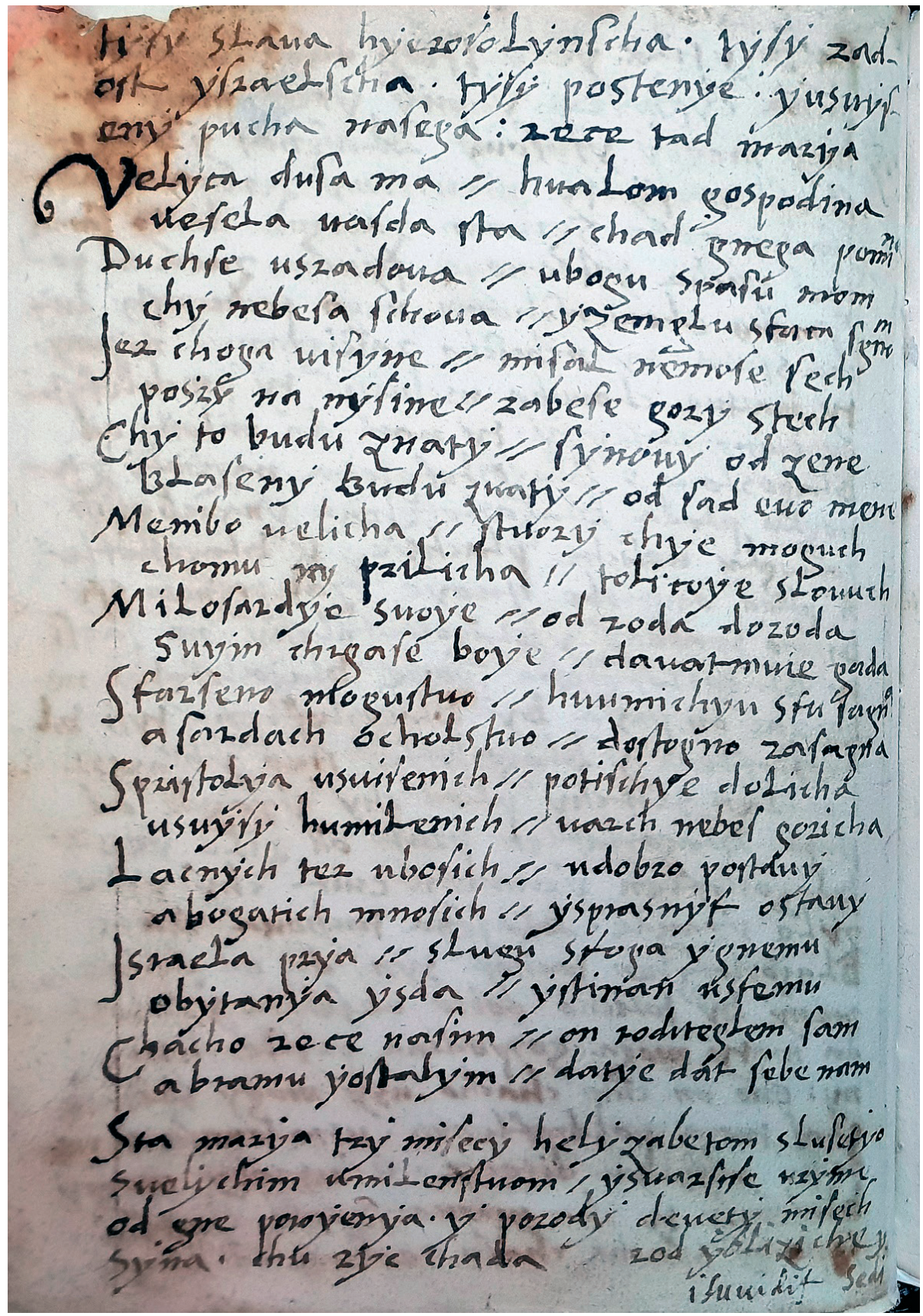


stado suoje da neçistoho oçisg. da usmichn oprosty do clomichn od griba oslobodi. Anga istannmicre isperglin de slipoga prosunieti. da ubogoga oslobodi daga istrmmicr is oborat : Sicm ocurus est. ad perres nostros. abvan et semini cius :

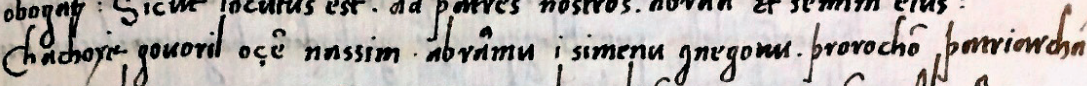
izmo nbrenmn reger. In semine neo bengdiceter omnes geres. Abraime posimenu tuoma suni nowodi hom bir blagosloughem. 3 acs moj sin chohesse

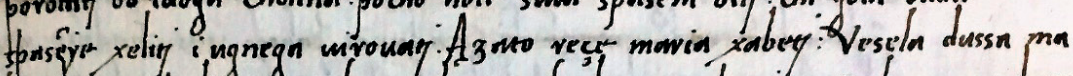

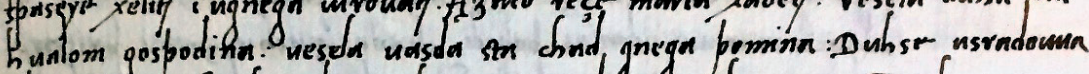

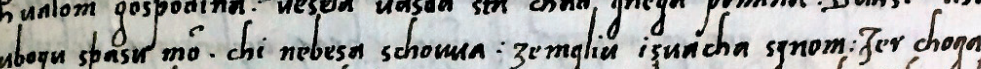

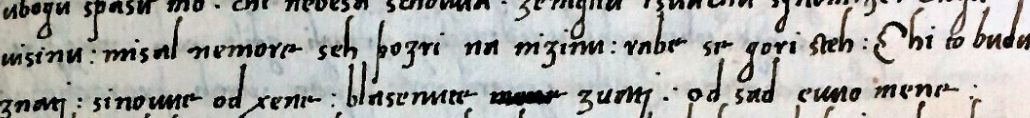

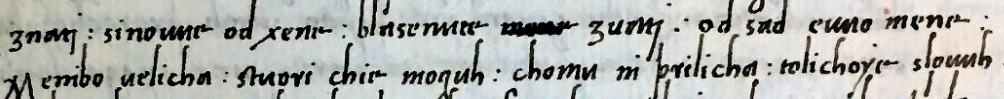
Memibo uelicha : suovi chir moquh : chomn in prilicha : rolichoyr sloewh

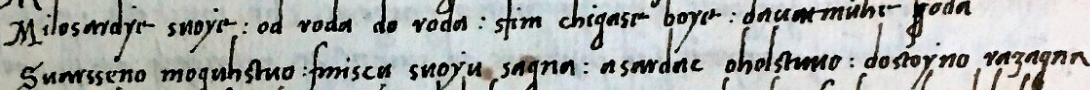

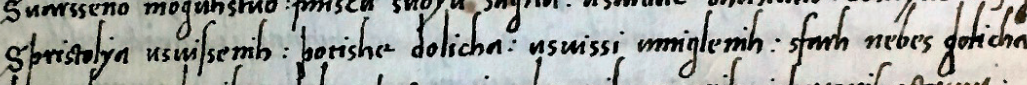

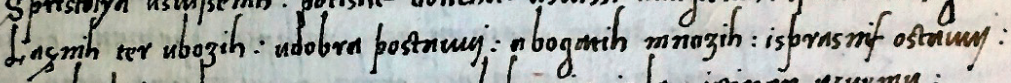

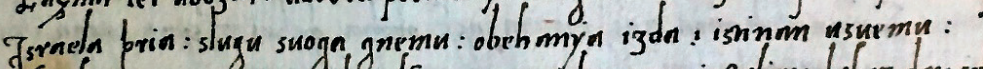
Gacho rece nassion: rodiregle on sam; nbrnamm iostulim: disho dar sebre nam

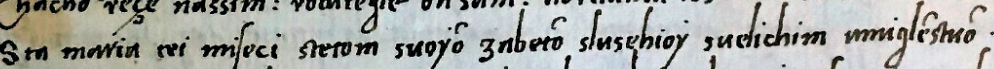

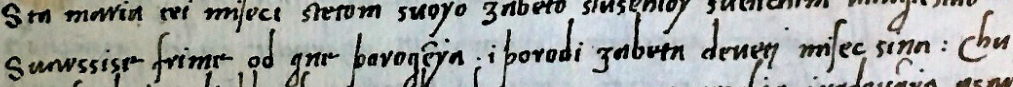

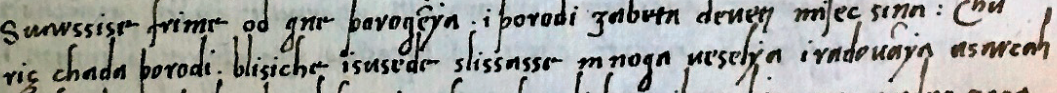

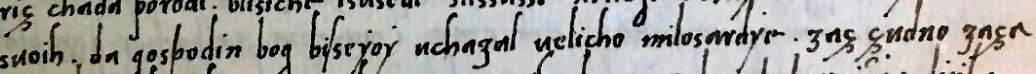

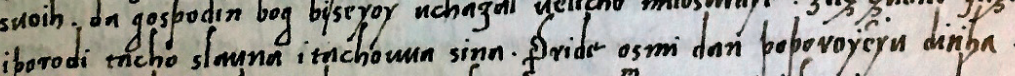

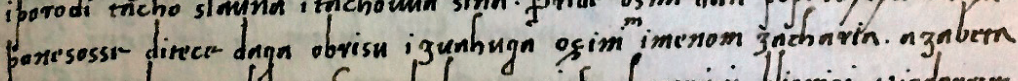

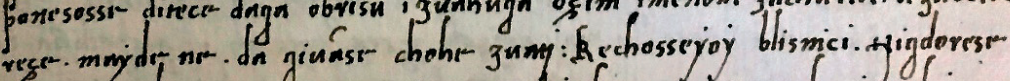

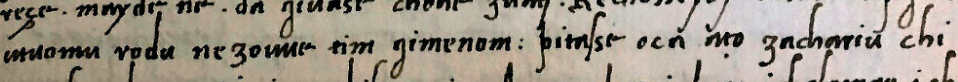

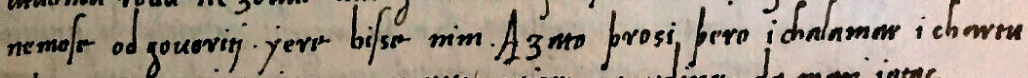

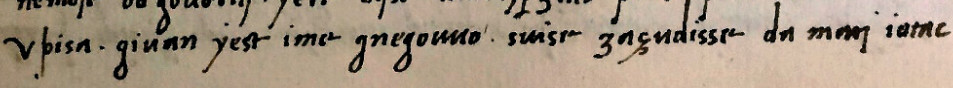

Sl. 3. Firentinski zbornik, Ashb. 1582 (No 1), f. 12 


\section{Marulićeva Biblija i egzegeza Magnificata na hrvatskom}

Kada je talijanski paleoslavist Carlo Verdiani (1905. - 1975.) god. 1953. otkrio Firentinski zbornik opisao ga je u svojoj velikoj i učenoj publikaciji (1957) "Il codice dalmatico-laurenziano. Ms. croato dei primi deceni del XVI secolo«. Iste je godine Josip Badalić (1957), koji se dopisivao s Verdianijem, objavio svoj rad »Marulićevi hrvatski autografi u Arhivu Jugoslavenske akademije« i u njemu Ziuot blasenoga sfetoga Iuana Charstitela Marka Marulića iz najstarijeg dijela zbornika Vartal koji je u posljednjoj četvrtini 16. st. skupio Petar Lucić, a prvi put u cijelosti objavio Nikica Kolumbić (Lucić 1990). Verdiani (1973) je uz prijevod Hrvoja Morovića i Radovana Vidovića, dvojice vrijednih splitskih štovatelja Marulićeva djela, a uoči 450. obljetnice njegove smrti (1974), objavio knjigu O Marulićevu autorstvu Firentinskoga hrvatskog zbornika iz XV stoljeća i u njoj izdao prvi, izvorni dio zbornika (drugi dio su kasniji zapisi više osoba na praznim listovima), uključujući tu i usporedno kritičko izdanje firentinske i trogirske (iz Vartala) verzije Života svetoga Ivana Krstitelja. Međuovisnost obje inačice pokazala je da je zapravo riječ o jednom autoru odnosno izvoru, djelu koje je u firentinskoj inačici prošireno, te, kao i ina djela tog zbornika, stalnim obraćanjem prilagođeno spoljubljenoj sestrici kao adresatu. Ta je sestrica bila, po Verdianijevu zaključku, Marulova sestra, redovnica Bira, kod koje su se, po svjedočanstvu njegova biografa Frane Božićevića (2007: 31), nalazila »mnogobrojna književna djela i poslanice s poticajima na čestit i blažen život, što ih je na domaćem jeziku i vlastitom rukom napisao sam Marko«.

Verdiani je koristio interdisciplinarnu metodu istraživanja, počev od usporedbe vodenih znakova papira (filigrana) Marulićevih sigurnih kodeksa i novopronađenoga, sadržajnih paralela, mnogobrojnih Marulićevih - i ničijih inače - hrvatskih stihova ugrađenih u taj zbornik, koji je nastao prije negoli je ijedan stih Marulićeve poezije bio tiskan i proširen, ${ }^{14}$ latinskih predložaka, jezičnih i

Da su Marulićeva ina hrvatska prozna i pjesnička djela bila tiskana za njegova života, mogla su utjecati na mlađe pjesnike kao što je tiskana Judita (1521) utjecala na pjesništvo Hektorovića, Lucića i Zoranića. Međutim, poznati stihovi iz drugih djela Marka Marulića koji su uneseni primjerice u Firentinski zbornik, nisu ranije bili nigdje objavljeni, za njih je znao samo autor. Onaj koji je sastavljao zbornik imao je međutim pri ruci praktički svu njegovu i samo njegovu hrvatsku poeziju u rukopisu. Relevantno je dakle da u zborniku nema ničijih drugih stihova osim poznatih Marulovih autorskih i prevedenih, te onih koji inim autorima nisu pripisivani. I ti su po svoj prilici njegovi jer su vrlo promišljeno utkani u prozu. Iz Života sv. Ivana Krstitelja umjetničkom se ljepotom ističe, osim Magnificata, uvodna i završna pjesan u slavu Stvoritelja: Ti chi suitom Vladas, suarh nebes sidehi, odnosno, O chragliu angelschi, chis nebesa stuoril, kao i prepjev Petrarcina soneta CCCLXV Io vo piagendo i mei perduti tempi/ Plaçu fsud hodehi, minuto xiuglenye. Da 
stilističkih analiza, sadržajnih i biblijskih referenci i sl., što se pokazalo kao širok i dobro trasiran put za atribuciju tog kodeksa Marku Maruliću (Pandžić 2009: 50-106). Verdiani (1973: 32):

»Neovisno o činjenici je li DL [Firentinski zbornik] izrađen rukom nekog prepisivača, ili ga je netko pisao po diktatu, treba imati pred očima da se kaligrafske crte koje karakteriziraju DL mogu staviti uz bok onima u Cod. Ms. Vaticano Latino Nr. 5249, koji potječe iz Splita, na što upućuje zapis na poleđini tog rukopisa, također iz Splita: Inscriptiones repertae Salonis, a to je dobro poznato djelo Marka Marulića. Vatikanski rukopis ima isti tip papira kao i DL, istu marginaturu i paginaturu te isti filigran (sl. 19 [i.e. 9]). [...] Smatram da je ta sukladnost izvanredno uvjerljiva, bilo da pomišljamo na autorovu ruku, bilo da se radi - što je vjerojatnije - o prepisivaču koji je običavao raditi za Marka Marulića.«

Kada se k tomu uzme u obzir nekoliko isključivo njegovih pjesama koje su interkalirane u Firentinski zbornik, svaki onaj koji se je bavio kodikologijom zna da tu slučajne podudarnosti uopće ne može biti. Također ne može biti slučajno da je Firentinski zbornik ukrašavala i pisala ista ruka kao i latinski rukopis Hunter 334 iz Glasgowa (usp. Pandžić 2009: sl. 10ab). Taj sadrži Marulićve epigrame i komentare uz natpise starih isto kao i Vat. Lat. 5249, rukopis koji je Verdiani kodikološki usporedio s Firentinskim zbornikom. Sva su tri rukopisa, firentinski, vatikanski i glasgovski dakle iz jedne splitske pisarnice, one Marka Marulića.

Ovdje dodajem nove dokaze za Marulićevo autorstvo Firentinskoga zbornika i Života sv. Ivana Krstitelja u njemu, kao i, posebno, u taj Život dvaput interkaliranog prepjeva, uključujući tu i jedinstveno izlaganje (ekspoziciju, egzegezu) Magnificata. To je, barem po momu sudu, prva egzegeza jednoga biblijskog teksta na novohrvatskome jeziku uopće. Umetnuta je u firentinski Život sv. Ivana Krstitelja, a nema je u inačici iz Vartala.

je zbornik pisao netko drugi onda mu pristup Marulićevim rukopisima ne bi uopće bio moguć, mnoštvo stihova u njemu uopće ne bi stajalo, odnosno, morao ih je dobiti od samoga Marulića koji je u vrijeme nastanka zbornika još bio živ. U tom bi slučaju taj navodni ini autor naveo koji su stihovi Marulovi. Jedino autor Marulić nema potrebe navoditi da sam ugrađuje, dograđuje i interkalira svoje stihove u razna djela svoga autorstva. Promišljena sadržajna i umjetnička kompozicija poezije i proze govori, međutim, isključio u prilog Marulova autorstva. 
Maruliću je Biblija bila nepresušno vrelo primjera (exempla) kreposnog života, ali i ljudske slabosti, navlastito oholosti, starozavjetnih slika i alegorijskih predložaka, zapravo skoro cijelo književno mu djelo, latinsko i hrvatsko, imalo je za ishodište Bibliju. U Splitu toga doba nitko nam nije poznat tko bi uopće tumačio Bibliju, a kamoli u tom opsegu i s takvim znanjem. I na koncu života, u svojoj oporuci, s velikom pomnjom popisuje i poklanja sve svoje knjige, na prvom su mjestu dvije Biblije, prva u četiri sveska »cum comento«, druga »sine comento«, te jedan vlastoručni sažetak, Compendium Bibliae.

Tu njegovu Bibliju »cum comento«, sačuvana je do danas, listao sam kao gimnazijalac u Splitu 1974., pa navodim nekoliko detalja oko nje. Navraćao sam tada kod fra Stanka Škunce, inače profesora latinskog i grčkog jezika, ${ }^{15} \mathrm{u}$ knjižnicu franjevačkog samostana na Poljudu, gdje se čuva daleko najveći broj splitskih inkunabula (usp. Badalić 1952). On je upravo u to vrijeme suhom olovkom bilježio folijaciju u sva četiri sveska te Biblije koju je Marulić oporučno ostavio poljudskim franjevcima, a pokazao mi je i njegove rubne bilješke i crteže koje je vlastoručno zapisao i oslikao. Svesci nisu imali u tiskari oslikane inicijale i folijaciju, mletački su tiskari tu dodatnu uslugu naplaćivali vrlo skupo, pa je Marulić nabavio manje raskošno izdanje latinske Biblije iz 1489. To su četiri sveska na preko 2000 tiskanih stranica (tiskar Bonetus Lucatellus) velikog formata (in $2^{\circ}$ ), a teška su zajedno barem desetak kilograma. Saznao sam da se Marulićeve obljetnice (450 godina od smrti) te godine nijedna od javnih ustanova nije sjetila. Iz današnje perspektive gledano, mislim da je Verdiani godinu dana prije, a nakon dvadeset godina istraživanja, uz Morovićevu i Vidovićevu pomoć, za tu obljetnicu ipak dao daleko više negoli je to mogao učiniti neki ad hoc skup toga doba.

Kada je pak Franz Posset, američko-njemački autor brojnih zapaženih knjiga s područja humanizma i reformacije, skoro četiri desetljeća kasnije pisao svoju knjigu Marcus Marulus and the Biblia Latina of 1489 (Köln 2013), pri čemu je analizirao sve rubne zapise, kristograme, križeve, kaleže, manikule i druge crteže u nastojanju da približi Marulićevu biblijsku hermeneutiku, savjetovao sam mu da se cijela ta Biblija presnimi i objavi na CD-ROM-u uz njegovu knjigu. Roland Marti, profesor slavenskih jezika i kulture iz Saarbrückena, urednik najpoznatije njemačke slavističke serije u kojoj su nekoć objavljena brojna djela

15 Studirao je u Rimu latinski i grčki jezik, gdje je objavio i svoju disertaciju pisanu latinskim jezikom o dubrovačkom latinskom pjesniku Iliji Crijeviću: Stanislaus Škunca, Aelius Lampridius Cervinus poeta ragusinus (saec. XV), Romae 1971. Njemu posvećujem ovaj rad. 
i rasprave iz hrvatske književnosti, među inima i prva hrvatska gramatika, čakavsko-njemački rječnik u tri sveska i sl., složio se, iako su time troškovi rasli. Međutim, nekoliko samozatajnih njemačkih i hrvatskih ljudi, ljubitelja hrvatske renesansne književnosti, tako jedinstvene u slavenskome svijetu, svojim su osobnim prilozima podržali izdanje, pa je knjiga objavljena, uz nju i cijela Marulićeva Biblija. Ne smije se prešutjeti ni dozvola franjevaca, ni veliki trud koji su uložili Branko Jozić i Bratislav Lučin iz Marulianuma u Splitu strpljivo danima snimajući in situ Bibliju bez pomagala koja imaju velike knjižnice. Oni su potom na svaki snimak stavili i elektronsku folijaciju, što danas bitno olakšava snalaženje i citiranje najvažnijeg metateksta književnih djela Marka Marulića. Zapravo, tko god htio izučavati genezu i produkcijsko-estetsku potku Marulićevih bilo latinskih bilo hrvatskih djela, tu Bibliju ne smije zaobići, dočim će mu Possetova analiza uvelike olakšati rad. Na primjeru Života sv. Ivana Krstitelja iz Firentinskog zbornika i u njemu interkalirane Marulićeve egzegeze Magnificata, želim pokazati zašto je to tako.

Slično Verdianiju (1957, 1973) Badalić (1957: 47) nije mogao »naći izvornika za Marulićev `Život sv. Ivana Krstitelja`«, ali je utvrdio da je ekspozicija "[...] rađena sasvim na temelju biblijske kronike po evanđelju Lukinom (I, 5-24, 57-80)«. I Parlov (2002: 446) razmišlja tako glede firentinske inačice: »[...] tekst uglavnom slijedi evanđeoske izvještaje, uz kratke meditativno-pjesničke dodatke koji se oslanjaju na svetopisamski predložak«. Međutim, osim na evanđeoski predložak, taj se tekst iz Firentinskog zbornika oslanja i na ekspoziciju (post illa), komentar Nikole de Lyra (1270/75-1349) na cijelu Bibliju, što dosada nije bilo poznato, iako je Posset (2013) utjecaj Lyrinih i Burgosovih komentara iz spomenutog izdanja Biblije na Marulića studiozno dokumentirao bilježeći sve rubne Marulove bilješke uz iste. Lyrina ekspozicija, uz uvode sv. Jeronima i dodatke Pavla iz Burgosa, čini i najveći dio spomenutog izdanja latinske Biblije. Nju je od 90-ih godina 15. stoljeća do preminuća 5. siječnja 1524. posjedovao i kao glavno pomagalo pri sastavljanju praktično svih svojih književnih djela koristio Marko Marulić. Taj nalaz ima dalekosežne posljedice za autorstvo izvornog i glavnog dijela Firentinskog zbornika do lista $120^{v}$, koji je ispisan jednom rukom, poglavito pak za Život sv. Ivana Krstitelja. Svi dijelovi rukopisa imaju brojne biblijske citate, pri čemu uz latinski tekst uvijek dolazi i hrvatski prijevod. Srodni Život sv. Ivana Krstitelja u Vartalu ima hrvatske, a izostavlja latinske citate. Navedenim tekstovima autor je Marko Marulić. 
Za ilustraciju te teze i Marulićeva načina rada donosimo usporedno po nekoliko rečenica iz Života sv. Ivana Krstitelja na hrvatskome u izvornoj grafiji (ipak $s$ umjesto $\int$ ) i njihove latinske predloške iz Lyrine ekspozicije. Prepisujem cijeli u tom Životu interkalirani hrvatski Magnificat, no ne i cijelu Marulovu ekspoziciju, što bi opsegom još više premašilo zadane okvire ovoga priloga. Time želim dokazati da je Marulićeva rečena Biblija, dakle ne samo biblijski tekst Vulgate koji je uvijek isti, nego i postila (ekspozicija) Nikole iz Lyre, tj. tekst koji nije dio same Biblije, a dolazi samo u njegovu komentaru, također bila predložak Firentinskoga zbornika. Samo onaj tko je $u$ Splitu pri ruci imao Bibliju >cum comento Nikole iz Lyre mogao je sastaviti zbornik. ${ }^{16}$ Da je upravo to izdanje koristio Marko Marulić dokazuju njegove - vlastoručne - rubne bilješke na primjerku te Biblije kao i brojni prevedeni citati i parafraze Lyrinog komentara u hrvatskom tekstu zbornika. ${ }^{17}$ Uz Lyrin latinski tekst hrvatske prijevode i parafraze donosim podvučeno.

16 Dodatke Pavla iz Burgosa na istu Bibliju ovdje još nisam detaljno istraživao, iako je za pretpostaviti da ih je Marulić tu i tamo također preuzimao jer je u samoj Bibliji svojeručno stavljao bilješke i uz njih, što je minuciozno popisao Posset (2013: 219-231).

17 Time se dokazuje da je u Splitu toga doba samo Marulić i posjedovao i glosirao Bibliju s Lyrinim komentarima. Doduše, u dominikanskom samostanu postoji još jedno izdanje Biblije s Lyrinom postilom iz 1481. (Badalić 1952: nr. 206), ali taj primjerak nitko nije glosirao, također nije poznato da bi itko od splitskih dominikanaca u to doba pisao hrvatske tekstove. Međutim, splitskom dominikancu Luki Urmaniću, knjižničaru samostana, Marulić je oporučno ostavio, uz brojne knjige, i danas izgubljeni, vlastoručno napisani sažetak Biblije (»compendium Biblie manu mea conscriptum ac per me compilatum «). Upravo je taj compendium Marulić najvjerojatnije koristio pišući svoja latinska i hrvatska djela, pa tako i Firentinski zbornik (No1) i R 3662 (No14). Izvršitelji su oporuke compendium u nekoj zamjeni dali franjevcima na Poljudu (Zaninović 1950). Slično mu je djelo Repertorium (Marulić 1998, 2000) u kojemu su konkordirani ključni pojmovi iz djela klasične starine i otačke literature. Taj, rekli bismo sustavni i znanstveni pristup najvažnijim književnim uzorima njegovih djela, sama je srž Marulićeve filološke, teološke i hermeneutičke metode uopće. 


\begin{abstract}
Vmigleni chragl Dauid xelehi umnoxatj slusbu bosýu u templu naredi da duade set $i$ çetire popi da sluse $u$ crqui sfachi suoýu nedigliu. Meu chimi popi bi ẏedan imenom Abia od choga izaýde pop zacharia chi ẏimasse xenu po ime xabetu neplodnicu. Ti bihu xiuuili u miru strahom bosẏim obslusuýuhi zapouidi gnegouue. Bihu prisli obadua na starost ne imiýuhi ploda od utrobe suoyje. Prid urime i nedigla da zacharia bude slusit u templu. [...]
\end{abstract}

\section{Veliça dussa ma $\bullet$ hfalom gospodina uesela uasda sta $\bullet$ chad gnega pomina.}

Chacho dabi htilla rehi Maria: Ti mene chualis zabeta i usuisuýes, a ýa hualim i usuuissuỳem gospodina boga ${ }^{18}$ choga dobrota i milosardye meni suacha poda.

Duh se uzradouua $\bullet$ vogu spasu momu chi nebesa schouua $\bullet$ zemglu $i$ suuacha $s$ gnom.

Oni choi boga huali raduyje se gnegouua dussa. A zato pochle dussa u paruom uerssu huali boga i u drugom uerssu prauui da se duh gne uzradouua zaç bijsse puna duha sueta. [...]

A Maria se usradouua u bogu [...]. Vsradouua se anna chada ẏoy் bog sinna da samuela imenom i reçe: Exultavit cor meum in domino, usradoua se sarce moỳe u gospodinu. ${ }^{19}[\ldots]$
David volens ampliare cultum dei ordinavit de vigintiquatuor generationibus vigintiquatuor sacerdotes qui successive servirent per hebdomadas in templo domini. Et octava sors cecidit super Abiam ut ibi dicitur, de quo descendit iste $\mathrm{Za}$ charias. Et uxor illius de filiabus Aaron, [...] et nomen eius Elisabeth. [...] Erant ambo iusti ante Deum [...] incedentes in omnibus mandatis [...] et iustificationibus domini sine querela, [...] et non erat illis filius [...] eo quod esset Elisabeth sterilis, et ambo processissent in diebus suis [...] sorte exiit ut incensum poneret, ingressus in templum Domini.

Magnificat etc.

Quasi diceret Maria: O Elisabeth, tu me magnificas, sed ego totum deo attribuens ipsum magnifico in hoc cantico.

Ubi primo ponitur modus cantici, secundo subditur causa cantandi, ibi: quia respexit. Circa primum declaratur laus virginis tanquam magna cum dicitur magnificat, ut devota,

18 Vrlo lijep primjer Marulova prijevoda Lyrina komentara.

19 Maruliću je jasno da Magnificat po svojoj strukturi od tri dijela za uzor ima hvalospjev Ane (1 Sam 2, 1-10), iz njega citira uspoređujući radost Marijinu i Aninu, što na ovom mjestu Lyra ne čini. 


\begin{tabular}{|c|c|}
\hline $\begin{array}{l}\text { Jere choga uisinu } \bullet \text { misal ne more seh } \\
\text { Pozri na nisinu } \bullet \text { rabe gori steh. }\end{array}$ & \\
\hline $\begin{array}{l}\text { [... Vmiglenstuo marie bi nebescha } \\
\text { schalla po choý bog ch nam priẏde, } \\
\text { oholast adamouua smart çinj na suuit } \\
\text { prijtj. Vmiglenstuuo marie xiuot nam da. } \\
\text { Diuua maria nayjpria ima humiglenstuo } \\
\text { na sarcu pach na ustih. [...] }\end{array}$ & ibi: anima mea non tamen labia mea. [...] \\
\hline 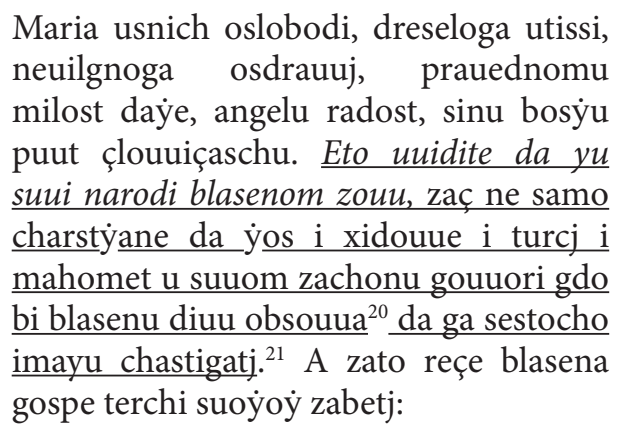 & $\begin{array}{l}\text { Ecce enim ex hoc beatum me dicent omnes } \\
\text { generationes, id est Judaei et gentiles. } \\
\text { Ex omnibus generationibus aliqui sunt } \\
\text { conversi ad fidem qui confitentur istam } \\
\text { virginem beatam. Hoc enim patet in } \\
\text { Saracenis, unde in Alchorao Mahumeti } \\
\text { dicitur de Maria virgine. }\end{array}$ \\
\hline $\begin{array}{l}\text { Chi to budu znatj } \bullet \text { sinouue od xene } \\
\text { Blasenu te zuuaty } \bullet \text { od sad euuo mene. } \\
\text { Meni bo uelicha } \bullet \text { stuori chino efsemoguch } \\
\text { chomu ni prilicha } \bullet \text { tolicho ye slouuh. }\end{array}$ & \\
\hline $\begin{array}{l}\text { Vçini mi mnoga chi e moguh zaç mi da } \\
\text { sedam dari duha suueta, ginim dil milostj } \\
\text { suoỳe da, a meni suu suuoýu milost } \\
\text { darouua. [...] }\end{array}$ & \\
\hline $\begin{array}{l}\text { Milosardye suoje } \bullet \text { od roda do roda } \\
\text { suuim chi ga se boye } \bullet \text { dauat mu ye goda. }\end{array}$ & \\
\hline
\end{tabular}

20 Očito je psovka u Splitu bila poznata i u Marulovo vrijeme, pa se bori protiv nje.

21 Ovdje preuzeti Lyrin citat o Muhamedu i njegovu zakonu jedinstven su dokaz Marulićeva autorstva ekspozicije jer je on u svojoj latinskoj Bibliji na šest mjesta (Posset 2013: 228) vlastoručno stavljao bilješke praktički uza sva mjesta gdje Lyra i Burgos spominju Muhameda i Kuran. Zanimanje islamom proteže se - što izravno što neizravno - većinom njegovih djela. 


\begin{abstract}
[...] Ne samo grisnichom milosardy்e uchasa da yoshe i prauadnim i ocem i sinom. Cho milosardye dauuid proroch humigleno prossasse gouorehi bogu: Ostede nobis domine misericordiam tuam et salutare tuum da nobis. Pochasi nam gospodine milosardye tuoẏe i spasenye tuoẏe day் nam. Cho milosardy்e uchasa chada prijde s nebes na zemgliu za nasse spaseny், propter nostram salutem.

Sfarsseno moguhstuuo • fmiscu suoyu sagna

a sardac oholstuuo • dostoyno razagna.
\end{abstract}

Bog uchasa moh u misci suoýoy், misca bosýa ýest sin bosýi. ẏere chachonot çlouuich suoýom miscom dillo çini tacho otac nebeschi uas suit po sinu suomu stuori i uçini. [...]

Oholi xidouuue chi se narugasse ouom miscom ne htisse u isusa uerouatj dispersit, rastarcha ih i rasagna po suuitu, yere po smartj isusouuj çettardesset i duua lita prigdosse rimglane titto i uespasian chi $\underline{\text { hýerosolim rasualisse }}^{22}$ xidouue pobisse $\mathrm{i}$ pohitasse i prognasse po suuitu. Od tada do danaznega dne i fsachi dan uuidimo da bog oholih chastiga.

S pristolya usuisenih • potishe dolicha

Vsuuissi humiglenih • sfarh nebes goricha.
Et misericordia eius, id est beneficium incarnationis quod ex misericordia dei factum est. Unum patebat David: Ostede nobis domine misericordiam tuam [...].

[...] in filii tui incarnatione.

Fecit potentiam in brachio suo, id est in filio suo, qui vocatur brachium domini, Isaia 53. Brachium Domini cui relevatum est.

Dispersit superbos, id est legiperitos et phariseos qui fuerunt superbi [...]. Et ipsi cum ceteris Judeis 42. anno a passione christi fuerunt capti et captivati per Titum et Vespasianum et per orbem dispersi.

R 3662 (No14), f. $19^{\mathrm{v}}-20^{\mathrm{r}}:^{23}$

22 Tema `rasutja jerosolimskoga` (usp. Orationes ex Egesippo, De excidio Hierosolomitano, obično dodatak uz De bello Judaico Josipa Flavija, obje na oporučnom popisu Marulićevih knjiga) u doba Tita i Vespazijana Marulićeva su trajna preokupacija. O tomu se govori i u apokrifnim Acta Pilati koja je preveo na hrvatski (1513), a sačuvana su u dva prijepisa (Hamm 1987), No 9 se danas čuva u Beču (Od rasutja jerosolimskoga), a No 11 (Kako Pilat pisa $k$ Tiberiju cesaru) u Londonu.

23 Zbog uštede na prostoru i zbog toga što je tekst izravno usporediv s onim iz Firentinskog zbornika na ovom mjestu unosimo instruktivan popis nedjela i kazni »za volju oholosti«. Lyra toga nema, tekst je dakle i lijevo i desno Marulićev. 
Bog potishe i uarse dolicha suich chi se usoholisse na nebu goricha. Oholi lucifer bi prognan is chragleustuua nebeschoga, i adam is raýa zemalgschoga za uogliu oholastj. Bog pogubi chraglia senacheribu, uoẏschu sfu, yednu noh sto i osamdeset i pet tisuh, i napochon sini mu glauu odsichosse za ciha oholastj. Chragl saul cih oholie chraglieustuo pogubi. Cragl nabuchodonosor pogubi pamet $i$ prognan bi is kragleustuua te xiuino trauu grizisse chacho uuol.

A suachoga chi bi humiglen bog ga usuissi. Vmiglen bi abraam [...] umiglen bi moises [...] umiglen bi dauid [...] umiglen bi hỷeremia proroch [...] umiglen bi giuuan charstitegl [...] umiglena bi maria [...] umiglen bi gospodin isus [...].
A sada slisaite cholicho strasno i zestocho bog castiga i pedipsa superbih i oholih. ${ }^{24}$

Oholast angela progna is nebes chacho pise isaia proroch $c^{o}$ XIII gouorechi: Quomodo cecidisti lucifer, chacho se upade is nebes lucifere za uogliu suoje oholasti.

Za uogliu oholasti progna bog adama nascega otca i mater euu is raia zemaglschoga.

Za uogliu oholasti uaze bog craglestuo roboamu sinu salamunouu III Regum $c^{o}$ XII.

Isaie $c^{o}$ XXXVIII. Za uogliu oholasti bog castiga cragla senachariba zac angel nebeschi pobi mu u jednu noch sto i osamdeset i pet tisuch uoische. Napokon sini gnegoui ubise ga.

Daniel $c^{\circ} I I I I^{\circ}$. Za uogliu oholasti castiga bog craglia nabuchodonosora zac mu pamet uaze i progna ga izmeiu gludi i stasce u pustigni ziuinom giduchi seno chacho uol.

Machabeorum co IX. Za uogliu oholasti castiga bog craglia antiocha zac ga fsega israni. che rane tolicho necisto uognahu da se ne mogase poli gnega stati is chih carui chipglahu.

Hester $c^{\circ} I_{I I I^{\circ}}$. Za uogliu oholasti aman bi na uisalih obisen.

Ludith $c^{o} X I I I^{\circ}$. Za uogliu oholasti castiga bog glutoga oloferna zac mu sueta udouica iudit glauu odsice.

Exodi $c^{\circ}$ XXXIIII ${ }^{\circ}$. Za uogliu oholasti bog potopi u carglenom moru craglia farau$\underline{\text { na. }}$ 


\begin{tabular}{|c|c|}
\hline $\begin{array}{l}\text { Laçnih tere ubosih } \bullet \text { u dobra postauui } \\
\text { a bogatih mnosih } \bullet \text { isprasnif ostauuj. }\end{array}$ & 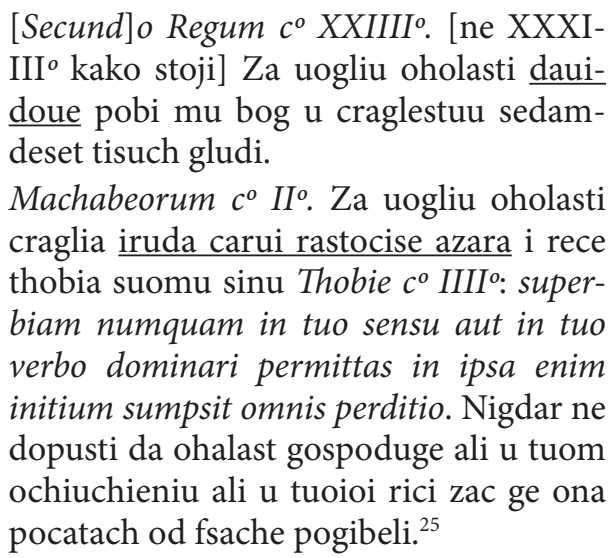 \\
\hline $\begin{array}{l}\text { Pria nere isucharst na sa suit prijde gliudi } \\
\text { bihu laçni duhofnoga blaga yere ne zna- } \\
\text { hu istine. Ni prauoga stuoriteglia ni mu } \\
\text { se chlagnahu negoli idolom. Samo xido- } \\
\text { ue bihu bogati zaç zachon bosỳi imahu }\end{array}$ & $\begin{array}{l}\text { Deposuit potentes de sede, } \underline{\mathrm{id} \text { est iudeos }} \\
\text { qui erant potentes in lege et prophetis di- }\end{array}$ \\
\hline i nauci suetih prorochof. Chada prigde & mittens eos ex suo demerito in profundo \\
\hline isucharst na sa suuit xidouue ne htisse & erroris secundum quod dicitur Ro. II [sc. \\
\hline $\begin{array}{l}\text { uirouatj u gnega. Meu suoih pride e ne } \\
\text { priasse gnega. [...] A pogane, chi bihu }\end{array}$ & $\begin{array}{l}\text { XI]. Caecitas ex parte contingit in Israel. } \\
\text { Et exaltavit humiles, id est gentiles hu- }\end{array}$ \\
\hline marli duhounim gladom, chi bihu laçni & militer et devote predicationem aposto- \\
\hline dusseunoga blaga yer istine ne snahu, ue- & lorum suscipientes, et ideo subditur: Es- \\
\hline rovasse $\mathrm{u}$ isucharsta, ter se nasitisse i na- & urientes implevit bonis quia gentiles cum \\
\hline punisse sfachoga dobra i blaga na ouom & magno desiderio quod per esurientem \\
\hline $\begin{array}{l}\text { suuitu ýstine i milostj, a po smartj hote se } \\
\text { napunitj slaue nebesche kada isucharsta u } \\
\text { suoýoy } \underline{\text { slauui uuide. }}\end{array}$ & designatur, verbum dei reciperunt. \\
\hline
\end{tabular}

25 Sve te primjere i kazne "za volju oholosti«, ponegdje i istim slijedom, nalazimo i u latinskim djelima Marulićevim, uz ona koja je naveo Parlov (2002: 446-450), navlastio u njegovim Starozavjetnim ličnostima (Marulić $1991=$ SDMM 7). Desetine primjera oholosti, među njima i skoro sve ovdje navedene, donosi konačno u svom Repertoriumu (Marulić 2000) pod natuknicom superbus, ali i na brojnim drugim mjestima toga djela. Među inima spominje i »Canticum Annę contra superbos « (1 Sam 2,1-10), što je inače glavni predložak za tekst Magnificata. To dakle nije slučajna podudarnost u tako brojnim biblijskim primjerima i tumačenjima, što je samo po sebi nemoguće pretpostaviti, nego, i prije svega, jedan te isti teološki pristup, »čisto učenje« (usp. bilj. 3) u djelima istog autora, Marka Marulića. Višestruka konkordancija biblijskih primjera oholosti pretpostavlja očito onaj Compendium Bibliae koji u svojoj oporuci navodi Marko. Dakle, isključivo njegovo je stoga svekoliko kolacioniranje, i u hrvatskim i latinskim mu djelima, biblijskih primjera za volju oholosti - ob superbiam. Oba dijela rukopisa R 3662, a ne samo drugi, njegova su dakle autorstva. 


\begin{tabular}{|l|l|}
\hline $\begin{array}{l}\text { Israela pria } \bullet \text { slugu suoga i gnemu } \\
\text { obitouanya izda } \bullet \text { istinan u suuemu. } \\
\text { Chacho reçe roditeglem suoim on sam } \\
\text { abraamu i ostalim } \bullet \text { da he datj sam sebe } \\
\text { nam. }\end{array}$ & \\
[...] To milostiuuo obchanye ispuni gos- \\
podin bog onda chada posla sina suoga \\
na ofi suuit chada se uputj u priçistu diuu \\
mariu [...]. \\
A zato reçe maria xabetj: \\
$\begin{array}{l}\text { [slijedi cijeli gore otisnuti i preslikani in- } \\
\text { tegralni prepjev hvalospjeva iz Firentin- } \\
\text { skog zbornika] }\end{array}$
\end{tabular}

Brojni doslovni prijevodi i parafraze iz Lyrina komentara ne ostavljaju prostora sumnji da je Marulić napisao, bez obzira na prepisivača, ovu meditativnu egzegezu Magnificata. Međutim, barem isto toliko za atribuciju teksta Marku Maruliću govori i način na koji je on interkalirao prepjev hvalospjeva u svoju egzegezu. ${ }^{26}$ Biblijski hvalospjev u vlastitom prepjevu ne donosi tek na jednom mjestu kao druge stihove, nego ga još jednom zapisuje i s lakoćom usklađuje i sadržajno integrira, ali ovaj put egzegetski, stih po stih, s latinskim tekstom

26 To je važno naglasiti jer i danas postoje mišljenja (usp. Malić 2010) da je Marulićeva poezija u to toba mogla »kružiti« u rukopisu pa su je anonimni začinjavci po potrebi mogli preuzimati u svoje radove bez umjetničkih ambicija. Ti bi anonimci onda, bez obzira na pjesnički ili teološki kontekst samih stihova, bez obzira na pitanje tko je uopće u to doba u Splitu bio u stanju sadržajno i teološki smisleno interkalirati, izmijenjivati, nadopunjati nanovo kombinirati i integrirati Marulićeve stihove u razne prozne tekstove, na koncu mogli sastavljati tekstove poput Firentinskoga zbornika. Takve hipoteze pripadaju znanstvenoj fantastici. Jedini u Splitu toga doba koji je napisao po jednu latinsku i hrvatsku pjesmu, ali nije komentirao biblijske zgode niti pisao prozne hrvatske sastavke, Marulićev je prijatelj i biograf Frane Božićević. Međutim, upravo on veli da je Marko svojom rukom, dakle nitko drugi, pisao pobožna djela za svoju sestru Biru. A što se »kruženja« tiče dovoljno je reći da su Marulove pjesme kružile isključivo u njegovim hrvatskim rukopisima nastalima u Splitu za njegova života. Ni prijepisi nastali nakon njegove smrti nisu »kružili« posvuda, nego samo ondje gdje je izvornike ostavio sam Marko, tj. kod sestara benediktinki u Splitu i Trogiru (spomenuti zbornik, Oficij bl. Dive Marije, Vartal, Život sv. Jerolima itd.) i franjevaca, gdje su ih oni mogli prepisati i dopisati (Osorsko-hvarska pjesmarica). I Splitska pjesmarica trogirskoga kaptola sigurno stoji u svezi s ljudima i prijepisma iz Marulićeva okružja. Nije poznato da bi itko u cijelom 16. st. Marulićeve stihove svjesno preuzeo u svoje pjesme, a pogotovo ne u opsežna prozna djela, jer takvih - osim Marulićevih - nije ni bilo. 
i obratno. Broj je stihova u njegovu dvanaesteračkom prepjevu prema Vulgati udvostručen pa ih je on nanovo morao razdijeliti i uskladiti s biblijskim tekstom i obogatiti paralelnim Lyrinim komentarima. Potom dodaje druge biblijske reference i vlastita tumačenja što je već dobro poznat zahvat iz latinskih mu djela (Parlov 2002: 446-450). Cijela ta složena biblijska i pripovjedačka struktura nije međutim kraj njegovih egzegetskih nastojanja oko Magnificata, odnosno Života sv. Ivana Krstitelja, nego tako posloženoj teksturi traži i nalazi uz doslovni i duhovni smisao - u ovom slučaju posebno, ali ne manje i u Juditi itd. - sve na tragu osobnog umnog $i$ sjetilnog prihvaćanja poniznosti (humiljenosti, uljudstva) i otklona od oholosti, prema jednom citatu iz Tobije na oba načina (ali $u$ tuom ochiuchieniu ali u tuoioi rici); dakle upravo onako kako to i Marija svojim primjerom i hvalospjevom Veliča duša ma sve ljude poziva na nasljedovanje: "Diuua maria naypria ima humiglenstuo na sarcu pach na ustih «, što je Marulićeva parafraza Lyrina komentara uz prvi stih Magnificata: "anima mea non tamen labia mea «.

Već je Parlov (2002: 447) opazio specifično marulićevsku jukstapoziciju oholosti i poniznosti:

»Tako, primjerice, u tumačenju Marijina hvalospjeva Veliča, kao primjere za grijeh oholosti navodi primjere Lucifera, Adama, Senheriba, Šaula i Nabukodonozora. Iste primjere, premda ne po istome redu i na istome mjestu, nalazimo u drugim Marulićevim djelima, osobito u Evanđelista$r u$. No način na koji opisuje primjere previše je sličan a da bi bio slučajan, a i sam postupak je marulićevski. Naime, nakon što se opiše pojedina krepost, odmah se opisuje i njen suprotan porok i obratno.«

Naviše smo, usporedno s tekstom iz egzegeze Magnificata (lijevi stupac), na odgovarajućem mjestu naveli iste te biblijske primjere oholosti (desni stupac $\mathrm{i}$ sl. 5), gdje je autor popisao rečene i dodao još nekoliko drugih primjera oholosti poznatih iz inih Marulićevih djela, zapisanih istim stilom i skoro istim redoslijedom u kontekstu meditacije o sedam smrtnih grijeha kao pripreme za ispovijed redovnicama, i to iz spisa Pocatach od fsache criposti, milosti i dusefnoga utisenia (R 3662, ff. 19v-28 r NSK). To je inače No 14 (sl. 4) stare splitske zbirke pučkojezičnih hrvatskih rukopisa koju je sastavio Marko Marulić za svoju sestru Biru, a koju je trgovac knjigama i mletački opat Luigi Celotti (1759. - 1843.) 1825. rasprodao kod Christiesa $\mathrm{i}$ 


\section{Pocatacb od flacbe cipoofh. milofti -ichulefinoga utífertia.}

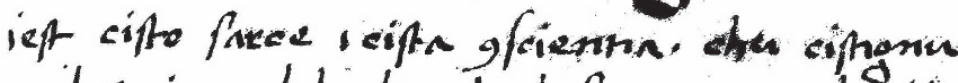
redaf nien dobude chadafe perane odyzihof iponi. Azato drugere fifter $n$ ifuehaxitu acho

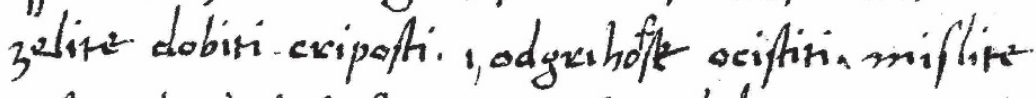
expto chachobafere prano ippovidale. Azaro chadn plifare viei chechiemo gonaviti ad fuete ponifi poftanifegih upamet y ufarea unfen. reue fiduchi foivchi tezechi fpat hodechi. inf-niuchife pominaitefe octorih idilomgih ippunite. y urfee minde nancite oue rici odfuete poniti. odche blazeni ayuftion gonovilcofofio af falus animay difiparcit

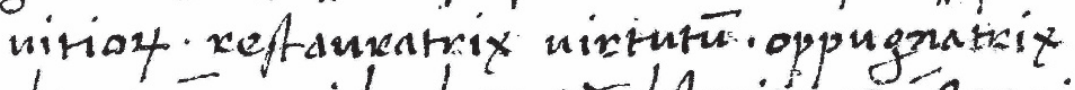

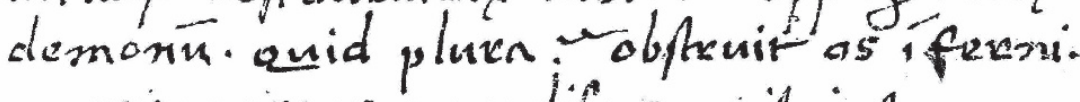
spperit poctas paendifims pouif iof

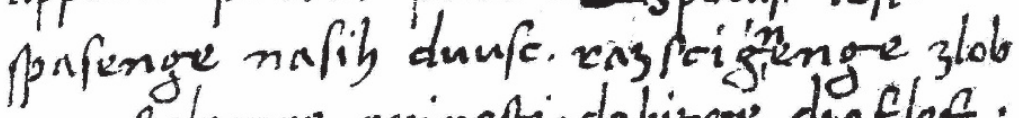
ponofglenge exipofti dobirge diaflof.

$$
\text { N.64 }
$$

Sl. 4. R 3662 (No 14), f. $1^{\text {r }}$. 
Sothebysa na dražbama u Londonu zajedno s brojnim inim i tek malobrojnim hrvatskim rukopisima. ${ }^{27}$ Iz ostavštine engleskih kolekcionara na dražbama u Londonu 60-ih i 70-ih godina 20. st. opet su ponuđeni neki od tih rukopisa pa je i rukopis No 14 (također No 12, No 13, No 21 i No 22) kupljen za NSK, opisao ga je Kulundžić (1977: 262-267), a rukopisi No3 i No9, sada HS 5, HS 6 i HS 4, za Slavistički institut u Beču.

No 14 prije desetak godina nije bio dostupan korisnicima, pa sam tek 16 . 11. 2018. obavio autopsiju i toga rukopisa. Ima 31 list, prvi dio s navedenim naslovom završava na f. $28^{\mathrm{r}}$, a sadrži teološki komentar i praktične upute redovnicama za ispovijed uključujući i teologiju sedam smrtnih grijeha, jednu pjesmu u dvostruko rimovanom dvanaestercu, a na kraju dolazi datacija i spominjanje autora koji međutim nije i pisar (f. $28^{\text {r }}$ ):

»[...] a onoga chi te chgnige ucini i upisa israni gospodine tuoiom gliubafgu necha te sa fsim sarcem glubi. dopustimu umigleno te molimo ono dobro quod oculus non uidit, nec auris audiuit, nec in cor hominis ascendit quae praeparasti diligentibus te. Milost bosia uasda da ti s gnim pribiua, a dusa gnegoua da slauu uziua, amen. MDXXXII. M.g.L.c. 3º idus augusti.«

Rukopis je dakle datiran 1532., no pravi je autor već umro, pa prepisivač želi »dusa gnegoua da slauu uziua«. Kraćenica M.g.L.c. nije jasna, o značenju

27 Celotti je trgovao ponajviše iluminiranim kodeksima, sitnoslikarsko umijeće učinio je popularnim i skupim u Engleskoj preprodajom vrijednih slika i rukopisa koje su opljčkali Napoleonovi vojnici, između ostaloga tako i minijature papina misala iz sakristije Sikstinske kapele. Iz njegove privatne, ne aukcijske, trgovine potječe i minijatura pripisana Juliju Kloviću (1498. - 1578.) iz Restauratorskog zavoda u Zagrebu Giudizio universale, koju je naručio papa Klement VII. (Eze 2016). Vrlo je vjerojatno da se on domogao rukopisne zbirke Marulićeve sestre Bire kada su Francuzi ukinuli samostan sv. Arnira u Splitu, gdje je Bira nekoć živjela, a rukopisi bili preneseni u Zadar u samostan sv. Marije. Nije jasno je li tu `posredovao netko iz obitelji Danieli i(li) Capogrosso da rukopisi dospiju u ruke Celottija. Jedno je ipak sigurno: njegov interes $z a$ te rukopise pobudili su prije svega inicijali Marka Marulića u više tih kodeksa, a najljepši su u No 6 (Add. 10394), njegovoj Instituciji na hrvatskom, koja se čuva u British Libraryju u Londonu (Pandžić 2009: sl. 22 i 23), tj. inicijali J i $M$ ispod križa u dataciji i autorskoj signaciji Marulića u kolofonu. Marko u oporuci svojoj sestri ostavlja jednu knjižicu blagovijesnog sadržaja koju je sam ispisao $i$ oslikao: "Eidem lego libellum meum cum picturis historiae euangelicae manu mea compositum atque depictum«. Stoga smatram da je Marko Marulić jedan od prvih hrvatskih minijaturista. Drvorez u drugom izdanju Judite (1522) s monogramom .M. potječe iz jednog djela Joachima del' Fiore tiskanog u Mletcima 1516., a radi se o monogramu mletačkog grafičara Mathea de Trevisa (Pelc 2006). To ipak ne znači da .M. nije Markov monogram. Marulić je s monogramom .M. uz dvije točke sa strane signirao i No 6 (Hrvatska Institucija, 1514), ukrašeno križem iznad gotičkog .M. kao podstolja, i No 9 (Dijalozi Grgura Velikoga, 1513), dakle prije tiska Expositiones Joachima del' Fiore. 
se može samo spekulirati, Maruli gratia etc. jedna je od mogućnosti. Drugi dio (f. $28^{v}-31^{v}$ ) donosi tzv. Legendu svetoga Jerolima u dvanaestercu (objavila Nazor 1975: 398-399) koja se ovdje zove Počinje život svetoga Jerolima. Pjesma je poznata iz više prijepisa i tiskanih djela, prvi put je objavljena glagoljicom u Tranzitu sv. Jerolima (Senj 1508). Obično se prvi stih uzima kao naslov: An'jelske kriposti nebeskoga hora (cijeli rukopis No 14, danas R 3662, je kao njegovo djelo na dražbi ponudila i aukcijska kuća Sotheby’s). Pjesma se nalazi i u Firentinskom zborniku (No 1), u R 6634 (No 21), te u dubrovačkom rukopisu 589, i tu kao i drugdje uz ine pjesme Marka Marulića, ali i uz već spomenute njegove vitae splitskih prvomučenika sv. Dujma i sv. Staša uz povijest prijenosa njihovih tjelesa iz Solina u Split. U njegovo autorstvo pjesme u dvanasetercu An'jelske kriposti kao i cijeloga rukopisa R 3662 ne treba dakle sumnjati. I prvi i drugi dio rukopisa su Marulova autorstva. Na posljednjem listu (f. $31^{v}$ ) nalazimo kasniji zapis jedne redovnice, najvjerojatnije iz zadarske obitelji Begna: S SOR OREA BEGNA. Prvo je S očito proba pera, a sve potvrđuje da je rukopis No 14, zajedno s drugim rukopisima iz izvorne Marulove splitske zbirke, prije rasprodaje $\mathrm{u}$ Engleskoj bio čuvan u samostanu benediktinki sv. Marije u Zadru.

Dakle, jedna snažna indicija u kombinaciji s navedenim biblijskim ličnostima i citatima, odnosno teološkim učenjem, postaje snažan dokaz za Marulovo autorstvo i ovoga rukopisa. Primjeri oholosti zapravo se međusobno nadopunjuju u Firentinskom zborniku, ovom rukopisu, Evanđelistaru, Starozavjetnim ličnostima i drugim latinskim djelima Marka Marulića, a sve te i mnogobrojne ine donosi i njegov Repertorium, vjerojatno je radio prema spomenutom Compendium Bibliae, što isključuje bilo kakvu slučajnost. Nova su dva primjera $\mathrm{u} R$ 3662 (No 14), no samo u odnosu na Firentinski zbornik, ne i u odnosu na druga njegova djela, pa oba potvrđuju Marulića kao autora rukopisa. Tu se naime spominju dvije starozavjetne žene koje su (ne)izravno kaznile ohole vladare, obje poznate iz književnih djela Marulovih. 


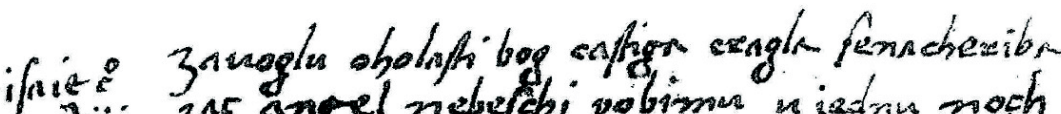

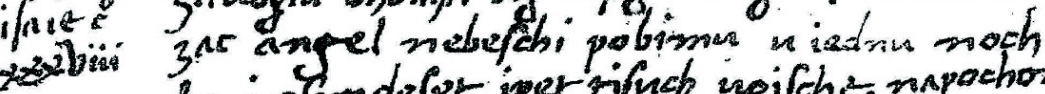
to iofnendefer iper rifuch, inoifhe napochon

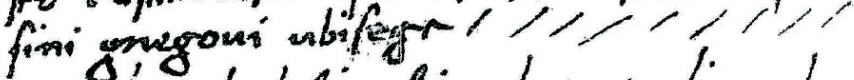

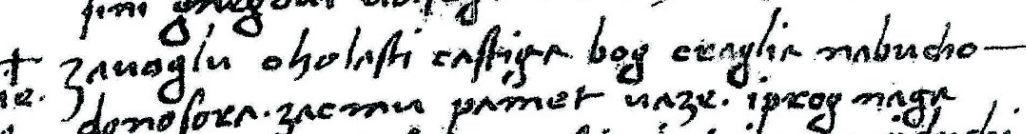

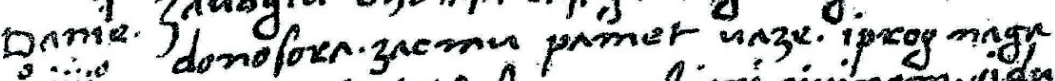

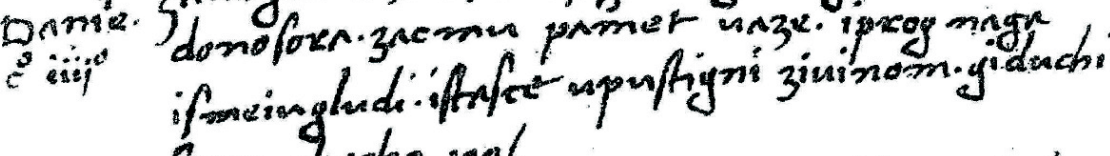

pens chacho not

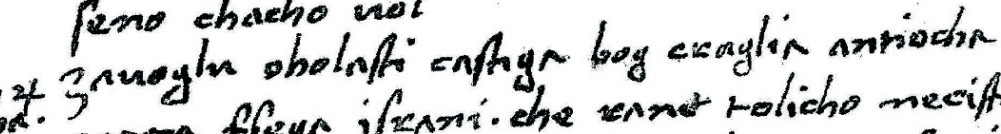

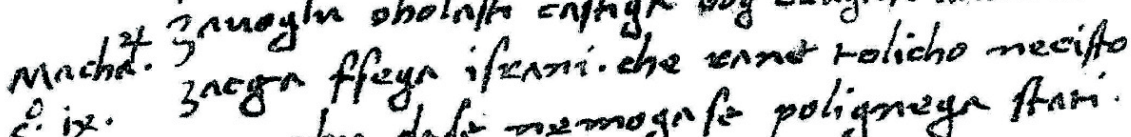

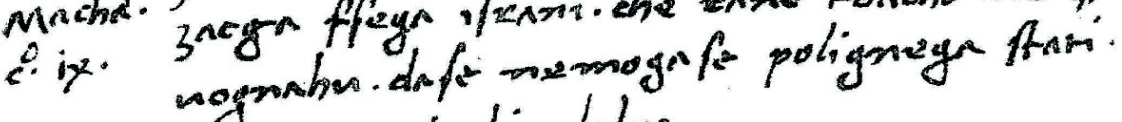
ichib, encusi chipglation

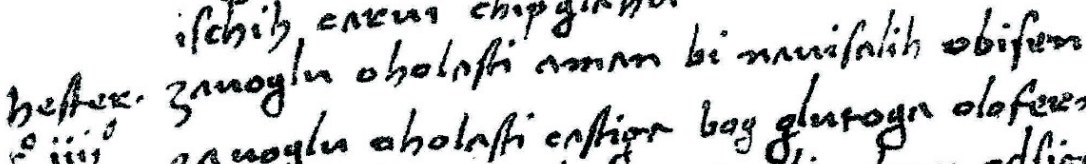

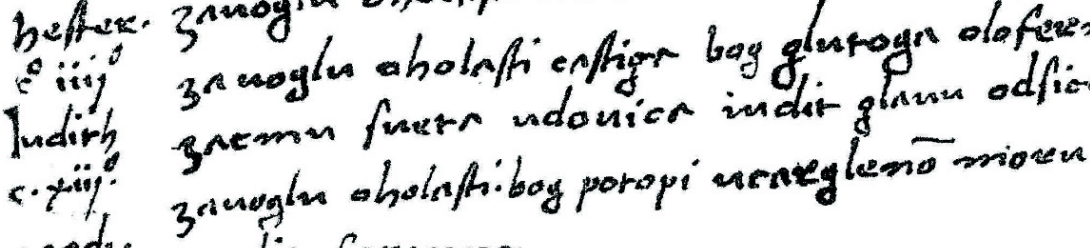

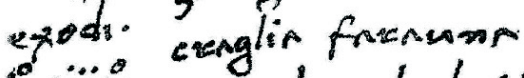

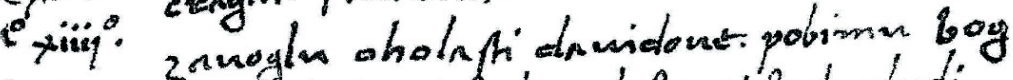

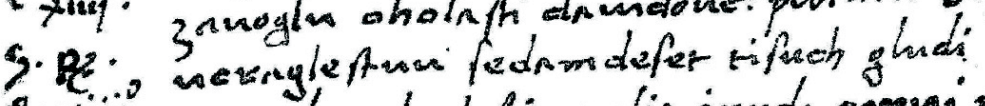

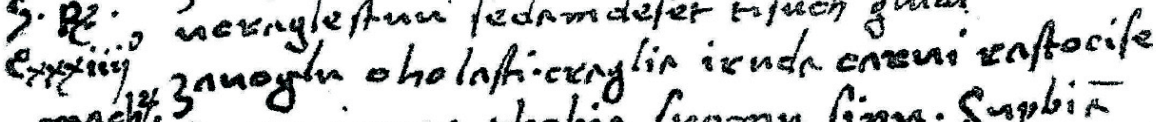
mach. Aznta izece thobin fromm finu. Sugbin

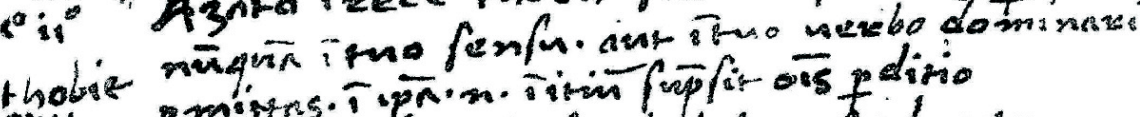

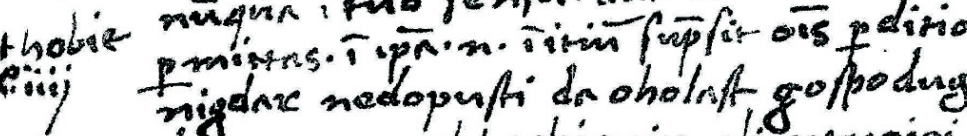

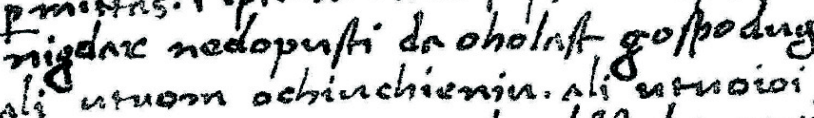

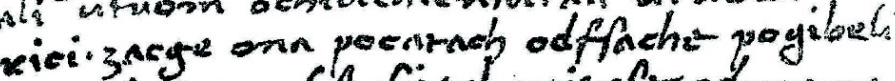

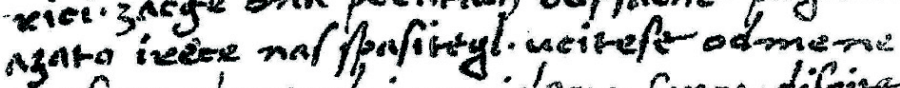
zacfam chreotan i nomiglena faucs. difeine

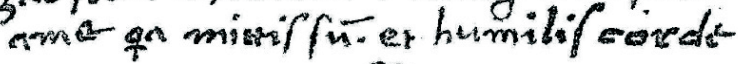
so

Sl. 5. R 3662 (No 14), f. $20^{\text {r }}$. 
Prva je Estera: »Hester $c^{\circ}$ IIII $^{\circ}$. Za uogliu oholasti aman bi na uisalih obisen «. U rukopisu R 6634 (No 21), ff. 48 ${ }^{\mathrm{r}}-50^{\mathrm{r}}$, Marulićeva je pjesma Od istorije Estera, gdje se pri kraju navodi: »[...] da pogine oholost // i na onu gredu amana obisisce [...] i tui obisisce // sine i amana « (f. 50r). Druga je žena svima dobro poznata hrabra Judita koja je pogubila Nabukodonozorova vojskovođu Holoferna, pa je njezinu hrabrost Marulić 1501. opjevao u istoimenom epu. U njemu su i inače vrlo brojni primjeri borbe uljudstva (humiljenstva) protivu oholosti (oholstva), što je zapravo i moralna pouka epa: »Judith $c^{o} X I I I^{\circ}$. Za uogliu oholasti castiga bog glutoga oloferna zac mu sueta udouica iudit glauu odsice« (`sveta udovica Judit ‘ je i izraz iz istoimenog epa). Isti taj uzrok, istih tih čina pogubljenja, hrabrošću istih starozavjetnih žena, opisuje Marulić (1991: 298-304), jedan pored drugoga, u Starozavjetnim ličnostima i - koliko znam - nitko drugi osim njega u hrvatskoj književnosti uopće.

U Životu sv. Ivana Krstitelja u Firentinskom zborniku ima više od 130 stihova, a 30 je stihova u istom Životu u Vartalu. Život iz Firence ima i ine Marulićeve stihove, tako i prijevod Pertrakina soneta CCCLXV Io vo piagendo i mei perduti tempi/ Plaçu fsud hodehi minuto xiuglenye. Sve te stihove i tekstove zbornika objavio je posebno i integralno u samom tekstu Verdiani $(1957,1973)$, davši i interdisciplinarnu analizu mogućih predložaka, bilo latinskih i talijanskih, bilo hrvatskih, latiničnih i glagoljskih. Konsekvence iz njegove analize nisu uopće bile ozbiljno propitivane u hrvatskoj marulologiji nakon Badalića (1957), dapače, bile su uglavnom ignorirane. Uz Tomasovića (1999: 260) i Parlova (2002) važan je izuzetak Nikica Kolumbić. On je u svome komentaru uz Vartal (Lucić 1990) na više mjesta potvrdio dokazbenu snagu Verdianijevih argumenata, navlastito glede Života sv. Ivana Krstitelja, u kojemu su kompozicijski vrlo inteligentno interpolirani razni stihovi preneseni iz drugih Marulovih pjesama, posloženi tu bez ikakva anakronizma i cezure.

Firentinski Život sv. Ivana Krstitelja sadrži 35, inačica u Vartalu (f. 259v) pet stihova iz Prikazan'ja historije svetoga Panuncija, Marulićeva prepjeva drame Fea Belcarija, koji je nedavno objavio Lučin (2017). On je (str. 6), uza svu hvalevrijednu akribičnost edicije, pošao barem od dvije pogrješne pretpostavke: a) »da nije sačuvan nijedan hrvatski autograf « Marka Marulića; b) da je Judita ne samo glavni nego i jedini orijentir za njegovu ortografiju (usus scribendi), jer su navodno »sva ostala hrvatska djela dostupna u prijepisima koji su svi nastali nakon Marulićeve smrti«, što, dokazano, nije točno. U najmanju ruku trebao je navesti i pobiti barem jedno suprotno mišljenje koje mu je poznato (Bada- 
lić 1957), i to ne samo zato što je Badalić najstariji umetak iz Vartala smatrao Marulićevim hrvatskim autografom, nego i zato što se $\mathrm{u}$ tom umetku nalazi i ovdje tematizirani Život sv. Ivana Krstitelja, a u njemu je integrirano i pet stihova (17-21) iz Prikazan'ja historije svetoga Panuncija, djela dakle koje Lučin izdaje kritički. Tih pet stihova su svakako najstariji hrvatski zapis te drame, a i oni u Firentinskome zborniku nastali su još za života Marulova. Lučin je stoga uz svoje izdanje morao procijeniti konsekvence i glede autografa i glede starosti rukopisa, ali i postaviti pitanje: tko je autor Života sv. Ivana Krstitelja iz Vartala i Firentinskog zbornika? Badalić (1957: 52) je to već davno učinio i logički zaključio: »Mislim, da ne će biti pretjerano, ako i tu povezanost `Prikazanja o sv. Panuciju $\mathrm{i}$ >Života sv. Ivana Krstitelja< protumačimo u korist istote autorove ličnosti tih dvaju književnih radova Marulićevih«. O starosti pak rukopisa (umetka) iz Vartala ne može biti sumnje, identičan je pisoruk i slovopis u No13 iz 1508. (R 6633), pa su otprilike u to vrijeme u Splitu zapisani i stihovi 17-21 prikazanja o sv. Panunciju, ${ }^{28}$ vjerojatno i malo ranije, no ne i prije 1495 . kada je tiskana editio princeps prikazanja koje prevodi Marulić (Lučin 2017: 38, bilj. 1). Da je i Firentinski zbornik mogao nastati još za života Marulova, Lučin ne spominje kada uzima u obzir (str. 38) četiri stiha (181-184) prikazanja za svoje izdanje prema jednoj fotokopiji kod Verdianija. Promaklo mu je međutim da je Verdiani (1973: 47-59) brojne druge stihove istoga prikazanja ne samo kritički obradio nego i u okviru Života sv. Ivana Krstitelja i objavio (str. 117-148). Time je postalo razvidno da je autor Života sv. Ivana Krstitelja poznavao Prikazan'je historije svetoga Panuncija u cijelosti (ne dakle samo pokoji stih), jer u Život interkalira stihove s početka, sredine i konca drame (17-20, 51-56, 151-154, 173-176, 181-184), što bilježi i Kolumbić (Lucić 1990: 781) oslanjajući se na Verdianija. Da se u istom Životu osim tih stihova iz prikazanja sv. Panuncija nalaze i brojni drugi, dakle ne samo Magnificat, Marulićev prepjev Petracina soneta Io vo piagendo i mei perduti tempi, prelijepi dvodijelni hvalospjev Stvoritelju, nego i neki stihovi iz pjesme Od kratka života koji se nalaze i u pjesmi Duša iz groba ove riči nam govori, a koju je Jagić (Marulić 1869) objavio kao Marulićevu, govori jedino o njemu kao autoru (Verdiani 1973: 53). No kako je Verdiani u Hrvatskoj od 1974. pa sve do danas bio uglavnom ignoriran i(li) vehementno osporavan,

28 Lučin za svoje izdanje koristi i puni prijepis drame iz Vartala, ff. 150 $154^{\mathrm{r}}$, nastao koncem 16. st., ali, vidjesmo, ne kolacionira stihove iz najstarijega dijela (f. $259^{\mathrm{v}}$ ) te zbirke, koji su pisani početkom toga stoljeća. U tom se dijelu zbirke uz Život sv. Ivana Krstitelja (ff. $255^{\mathrm{r}}-265^{\mathrm{r}}$ ) nalaze i Marulićevi prepjevi dviju drama (ff. 220 $-254^{\mathrm{r}}$ ), Govorenje svetoga Bernarda od duše osujene i Ovo jest skazanje od nevolnoga dne od suda ognjenoga, koje je objavio Jagić (Marulić 1869). 
slično i Badalić, dočim su neki autori koji Firentinskoga zbornika ni vidjeli nisu u svom uskom i zatvorenom krugu samocitiranja bili samopohvaljivani, moglo se naposljetku i Firentinski zbornik, kao i cijelu, ne knjigu, nego prvu biblioteku hrvatske pučkojezične proze uopće (Pandžić 2009), nastalu još za Marulova života u Splitu, ignorirati i na koncu proglasiti ni manje ni više nego »dubioznim tekstovima« (Kapetanović 2011: 7). Bez obzira na moguće ideološke konotacije te tvrdnje glavni je problem ovdje nepoznavanje stoljećima izgrađivane metode rada kritičke filologije o kojoj je nekoliko riječi već rečeno, a naniže će se još raspravljati. Cilj je metodološke i ideološke akrobacije nekih kroatista početno vjerojatno bio, a izgleda ponegdje i do danas ostao, ako zanemarimo poznati jal zza volju oholosti`, zatajiti brojna Marulova i ujedno primordijalna hrvatska djela pučkojezične proze, kako bi se možda moglo sspasiti ugled ‘ renesansnog pisca Marka Marulića. Taj ugled bi, izgleda, `narušavala‘ njegova općerazumljivim jezikom pisana vlastita ili prevedena proza bogobojazne tematike, prva hrvatskim jezikom pisana egzegeza, umjetnička poezija poput prepjeva Magnificata, te prve četiri drame (prikazanja) hrvatske književnosti uopće, a sve to opet napisano, po Danteovu uzoru, novohrvatskim jezikom visoke stilizacije, tj. na hrvatskome volgare illustre.

\section{Bilješke o metatekstu nekih dijelova Firentinskoga zbornika}

Još tri vitae nalazimo u Firentinskom zborniku: Život sv. Jerolima (ff. $\left.22^{\mathrm{r}}-31^{\mathrm{r}}\right)$, Život sv. Šimuna (ff. $31^{\mathrm{v}}-40^{\mathrm{r}}$ ) i Život sv. Vicenca (ff. $41^{\mathrm{r}}-52^{\mathrm{r}}$ ). Sve tri Verdiani je temeljito analizirao, posebice pak Život sv. Jerolima, koji u zborniku dolazi odmah iza Života sv. Ivana Krstitelja, dakle čak ispred Života sv. Šimuna i Isusova prikazanja u hramu (Lk 2, 21-40). To je odraz poznate Marulićeve želje da se život Jeronimov uspoređuje s Ivanovim, »noscitur comparandus« (Pandžić 2009: 103), jer je Ivan bio Preteča Gospodinov, dočim je Jeronim imao važnu ulogu kao prevoditelj Vulgate i tumač Riječi Gospodnje svim narodima, pa ga Marulić naziva »Ecclesiae nostrae Plato/ Platon crkve naše ${ }^{29}$ Međutim, ovdje se ne želim zaustavljati na tim životima s brojnim Marulićevim stihovima koji su u njih ugrađeni, pogotovo u Život sv. Jerolima, ni na prikazanju o sv. Margariti (ff. $1^{\mathrm{r}}-6^{\mathrm{v}}$ ), nego ću (usp. Pandžić 2009: 110sl.) samo ukazati na zanimljivo podrije-

29 Valja još spomenuti da Jeronima u Firentinskom zborniku (f. $24^{\mathrm{v}}$ ), također i u Jagićevu izdanju (usp. Bratulić 2014) trogirskoga prijepisa iste vitae, iznimno hvali: »Trudi se pedeset lit i sest miseci tumaçehi stari testament is chlaldeyschoga $\mathrm{i}$ is xidofschoga yasicha $\mathrm{u}$ latinschi, a nouui testament is garçchoga li u latinschi. To ye fsa biblia. Hyeronimus dalmata est. Hyerolim ye nas dalmatin. On je dicha i postenye slaua i suitlost, chruna haruachoga yasicha«. 
tlo prva tri od »tekstova poučnoga karaktera « iz toga zbornika (Verdiani 1973: 77-91): 1. Naçin pochi put ima se Gospodin bog moliti (ff. 52 ${ }^{\mathrm{r}}-61^{\mathrm{v}}$ ), 2. Tumaçenye

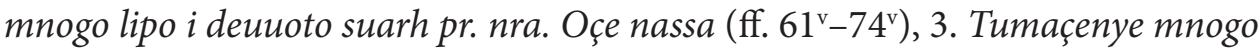
lipo i deuoto suarh ave Marie. Zdrauue Marie (ff. $75^{\mathrm{r}}-77^{\mathrm{rv}}$ ), 4. Mirachul mnogo lip choij uçini blasena gospe po chriposti s. rusaria (ff. $77^{\mathrm{v}}-83^{\mathrm{r}}$ ), 5. Mnogo lipo $i$ deuoto gouorenye suuarhu muche gospodina isucharsta slatchoga (ff. $\left.83^{\mathrm{r}}-120^{\mathrm{v}}\right) .{ }^{30}$

Prva tri teksta očite su parafraze nekoliko poglavlja (1-6) Marulićeva prijevoda (1508) Zardina od molitue, anonimnog djela (23 pogl.) namijenjenog ženama, Zardino de oration fructuoso, nastalog 1454., a tiskanog u Mletcima 1494. (usp. https://archive.org/details/ita-bnc-in1-00000100-001, pristup 29. 12. 2018.). U talijanskom izvorniku (sl. 7) stoji da je pisano 1454. u vrijeme kada je u Crkvi "presidente e vicario« bio papa Nikola V., dočim Marulić (sl. 6) u prologu aktualizira vrijeme, pa piše da je u Crkvi: »[...] poglauica i uicharii iullij papa drugi, techuchi godischia poroienia od nassega gospodina issusa Issucharsta tissuchia i petcat i ossam«. Osim toga bilježi: »Ja sam mislio za sloziti ouo dillouanie i ouo gouorenie od molitue haruacchi za da oue dusse nerazumne i simple mochi budu gimiti razuminie od oue molitue [...]«. U talijanskom izvorniku stoji da ništa nije vlastito nego je pisac sve našao u Svetom pismu i kod svetih doktora, pa to tako onda stoji i u hrvatskom prijevodu (»u chgnige od suetoga pisma i od suetih docturou«). To je važno naglasiti da se ne bi pomislilo kako se radi o djelu Marulova autorstva. Riječ je samo o njegovu prijevodu i pisoruku, a taj je prijevod poslužio kao glavno vrelo pri pisanju (parafraziranju, kraćenju, ponegdje s dodatnim biblijskim i teološkim dodatcima) tri poglavlja Firentinskoga zbornika. ${ }^{31}$ To bi značilo da isti zbornik nije mogao biti sastavljen prije 1508. god., iako je naravno Marul mogao već ranije imati svoje »radne rukopise« oba djela.

30 Ovo govorenje temelji se na jednoj propovijedi (sermo) dominikanca Gabriela de Barletta, na što je ukazao Vučković (2013).

31 Ovdje na to samo upućujem, a tko želi provjeravati tvrdnju neka usporedi navedena poglavlja (Verdiani 1973) i talijanski izvornik preko obilježene poveznice. U Firentinskom zborniku (f. $61^{v}$ ) tumačenje Očenaša počinje: »Pater noster. Necha znas sestrice pridraga da ouua molituua nadhodi suue ostale molituue u tri riçi«. U Zardinu pak stoji (f. $17^{\mathrm{r}}$ ): »Naẏpria gouorimo da oua molitua shody் ẏ nadhody் sue ostale molitue poglauito u trý ricy், u talijanskom izvorniku opet: "Pria dicemo che questa oratione excede e avancia tutte le altre principalmente in tre cose«. Izvornik otvara velike mogućnosti za nužno kritičko izdanje i Firentinskoga zbornika (No1) i hrvatskoga prijevoda Zardina (No13). Vrlo se brzo može utvrditi talijanski ekvivalent praktički svake hrvatske riječi i bolje razumjeti nastajanje novotvorenica. 


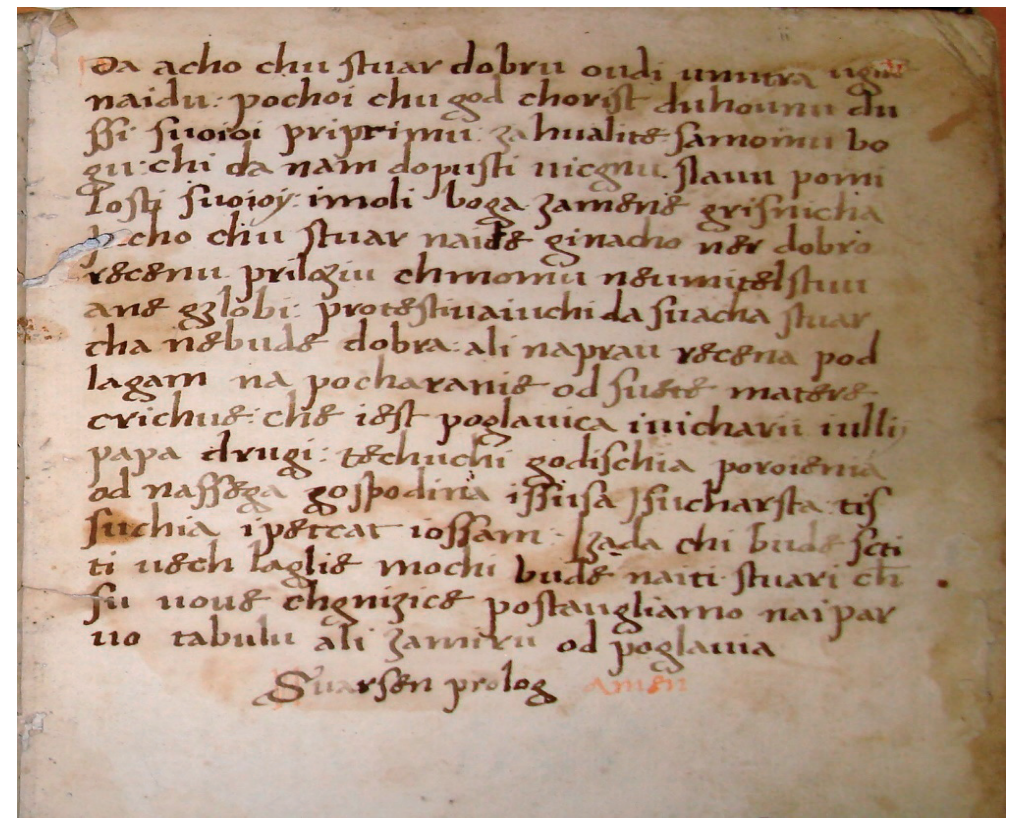

Sl. 6. R 6633 (No 13), f. $3^{\text {r }}$.

\begin{abstract}
atribuifca quello ala ígnozantia mia:nona malicia :pzotefando ebe ogni cola cbe non ía bene:o orittaméte orcta fottometto ala correctione oiciafcaduno vero fpirituale e feruo oi oio:e fpecials mente a cozrectione oela fancta cbiefa catbolica zala quale e pre fidente e vicario thicolo 1papa quínto. Eozendo li anni oe la natiuitade oel noftro fignoze Zefu cbuffo. Ansille quatrocento cinquanta quatro. Eacio cbel lectose piu facilmente pofia tro uare le cofe cbe fono ín quefto libzo poniamo in pzima la tatuota oeli capituli. S inito il 1Dzologo.
\end{abstract}

\title{
Sl. 7. Zardino de oration fructuoso (1494)
}

Međutim, kako možemo znati da je prevoditelj Marulić? Za to imamo nekoliko dobrih kodikoloških i filoloških indicija, uzete zajedno isključuju mogućnost da bi autor bio netko drugi. Rubne su bilješke vrlo zanimljive. Jedna (f. 13 ${ }^{\mathrm{r}}$, sl. 9) nesigurnom rukom upućuje na pisca i(li) vlasnika: »questo libro si e de m ", što bi se moglo prevesti s »ova knjiga je M[arulova]«. Druga (f. 104v sl. 8) dolazi umjesto kolofona, koji je zajedno s posljednjim listom rukopisa izgubljen, pa je zapis na koncu teksta, kao i kod prve bilješke, dodan kasnije: »a a mar[u]lo parl questo lauor exim[io] «, u prijevodu »na Marula upućuje (o Marulu govori) ovaj izvrsni rad «, što se po kodikološkoj logici i bilježi u kolofonu. Doduše, moglo bi 
se čitati i »a armarlo [...]«, dakle »na ljubiti ga (za oboružati se njime) upućuje ovaj izvrsni rad«. Ipak, kako to prvo $r$ nije pisano kao druga dva, prije će biti da je to crta koja odvaja prijedlog od imena. Tada bi naravno prvo $a$ bila proba pera kakvih je mnogo u ovom rukopisu, pa bi prvo čitanje moglo biti ispravno.

Bilo tako ili ne, treća rubna bilješka, zapravo crtež (f. 33v , sl. 10) u svakom slučaju govori o Marulu kao prevoditelju zbog njegove poznate predilekcije za karikaturne »brutissime figure« kao sredstvu opomene. Ondašnji predstavnik mletačke

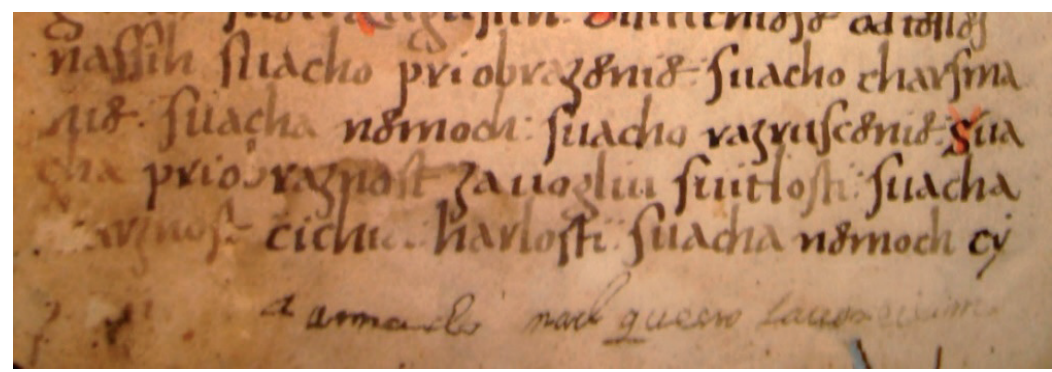

Sl. 8. R 6633 (No 13), f. 104v

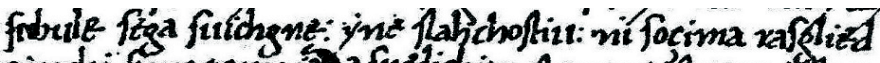

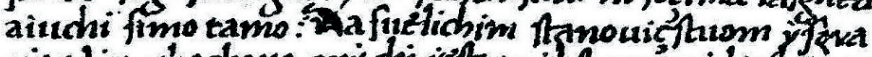

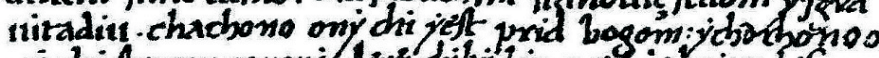
ny dhi pogam gouror: leve hibi bio prid yit nim brifetp.

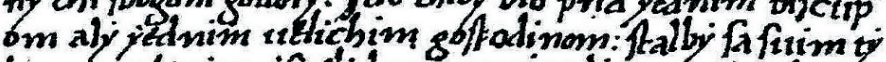

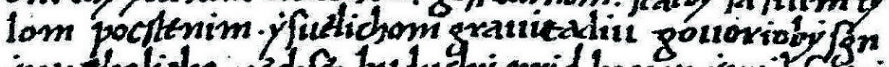

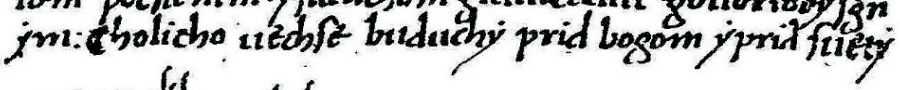
guestoliber siedem

Sl. 9. R 6633 (No 13), f. $13^{\text {r }}$.

biga ngedchal daby lò bal:y gna gne pojarauguenge

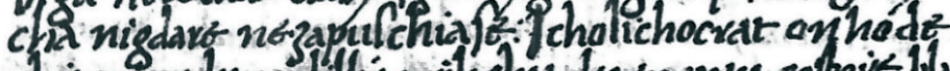
chy pogradu widibj prilichit dequencanter golpajt bl iens: hotif fecim Kochief aly ucho hoc najloyanyt

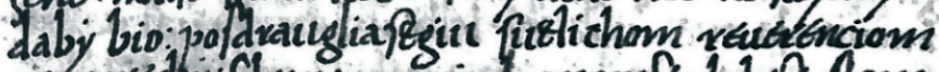

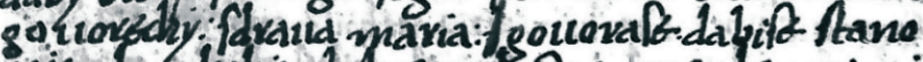

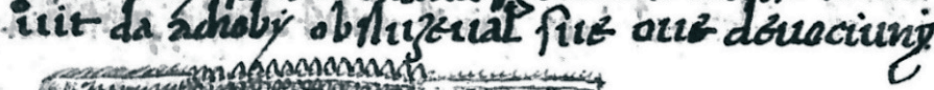

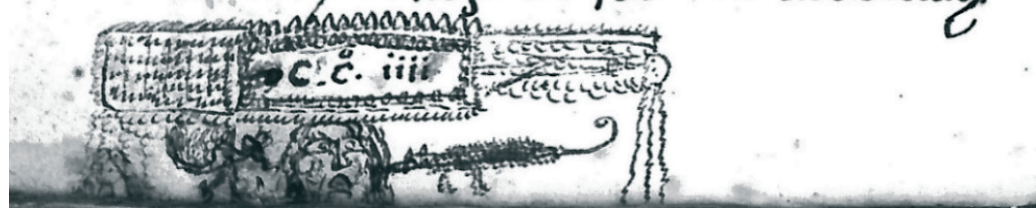

Sl. 10. R 6633 (No 13), f. 33v . 
vlasti, splitski knez Frano Celsi, 26. studenog 1518. piše naime vladi u Mletke, da raskalašena splitska mladež nakon berbe prione uz igre, trošeći sve čime bi trebala uzdržavati obitelji i roditelje, a prezirući (Fisković 1986: 404):

»[...] očinske opomene veoma učenoga gospara Marka Marula, starca koji jako cijeni gospodina Boga, kojima ih on opominje na trgovima pisanom i izgovorenom riječju, a i zastrašujućim prijetnjama i najružnijim likovima (brutissime figure). «2 $^{32}$

Jedna od tih `najružnijih figura kojima je Marko na velikim plakatima strašio mladež po ulicama Splita (performance sui generis) je u minijaturnom obliku ucrtana na f. $33^{v}$ rukopisa (sl. 10), gdje dva nezasitna glodavca grizu lice prestrašenog smrtnika, zacijelo s nakanom emocionalizacije, `oćućenja` prijetećih muka paklenih.

Što se grafije rukopisa tiče ${ }^{33}$ ona je najbliža, praktički skoro istovjetna, onoj iz najstarijeg dijela Vartala, što je i razumljivo jer oba rukopisa imaju isti pisoruk, ne samo po mom sudu i dubokom uvjerenju, Marulićev (usp. Badalić 1957). U pogl. 7 je uspoređena grafijska uzanca najvažnijih rukopisa s tipografijskim oblicima Judite (1521), čime se istorodne, marulićevske osobine ovih rukopisa dodatno potvrđuju.

Rukopis R 6633 (No 13), f. $16^{v}$ (sl. 11) sadrži i jedno poglavlje iz Dijaloga Grgura Velikoga, a ima ga i rukopis naše zbirke HS 4 (No 9), f. $47^{r}$ (sl. 12) jer taj sadrži cijeli tekst Dijaloga. Po leksiku je jasno, slovopis se malo razlikuje, da je

32 Fiskovićev rad (1986) donosi i vrlo korisna opažanja o Marulovu sitnoslikarskom umijeću, iluminacijama i ilustracijama knjiga, što se bez ikakve zadrške može prenijeti i na rukopise koje ovdje spominjemo, navlastito one oslikane. Fisković (str. 396), slično već Badalić (1957), govori o brojnim karakterističnim potezima pera, osmišljenim crtežima i slovima (pisoruku): » [...] bez traga labavosti i usiljenosti [...]. To su doduše malenkosti, ali se po njima prepoznaje ex ungue leonem, do sitnica i tančina precizni Marul«. Cijeli pisoruk rukopisa R 6633 (No 13) i umetka iz Vartala svjedoči o tomu. S druge strane, brutissime figure ruše ne samo slikarski nego i pisarski sklad.

33 Prolog je pisan većim slovima u kojemu ne koristi $\dot{y}$, iako je isti pisoruk u čitavom rukopisu. Prema Fiskoviću (1986) Marko je naslijedio (sitno)slikarsku nadarenost od svoga oca Nikole, koji je umio uspješno imitirati različite pisoruke. I zbog toga uvijek valja biti oprezan pri prosudbi što je Marulićev pisoruk, a što ne. Kao kontrolne instancije mogu poslužiti slovopis i morfologija, a navlastito specifičan leksik, prevedenice i brojne novotvorenice. Primjerice, u Dijalozima (1513) Hamm nalazi stotinjak hapax legomena, a od tih se skoro polovica nalazi već u Marulićevu Naslidovan 'ju (1500), djelu koje Hamm nije mogao kolacionirati, objavljeno je 1989. (Pandžić 2009: 123). Već na prvi pogled neke od tih riječi ima i Zardin (1508), ali i drugi ovdje uspoređeni rukopisi. Za tradicionalnu kritiku teksta ta je međuovisnost preko hapax legomena neoboriv dokaz Marulova autorstva svih na taj način međuosvisnih rukopisa, dakle kroz riječi koje je on prvi uveo u hrvatski jezik. 
obje inačice prevodio jedan čovjek. Povezanost rukopisa je neupitna, bez obzira na različite pisare. Kako su te rečenice parafrazirane već na talijanskome u $\mathrm{Za}$ rdino de oration fructuoso (1494), mogu se uočiti sitnije razlike u prijevodima. Marulić je, po svoj prilici, cijeli tekst Dijaloga kasnije prevodio i diktirao bez obzira na poglavlje iz No 13. Međutim, Dijalozi Grgura Velikoga u svakom su mu slučaju već 1508. bili poznat tekst, dočim je prijevod cijeloga teksta u HS 4 (No 9) zgotovljen 1513. Zanimljivo je da je rukopis Dijaloga ukrašen i brojnim oslikanim inicijalima, oblikom upravo onakvima kakve ima tiskani Zardino de oration fructuoso (1494). Očito je dakle da su hrvatski prijevodi Zardina od molitve (No 13) i Dijaloga Grgura Velikoga (No 9) nastali u jednoj te istoj pisarnici, opet onoj Marka Marulića u Splitu.

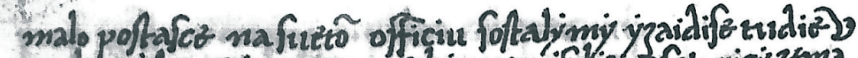

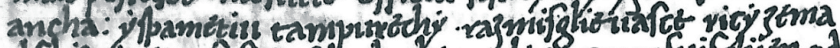

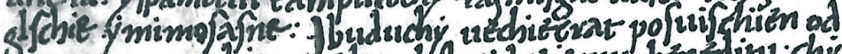

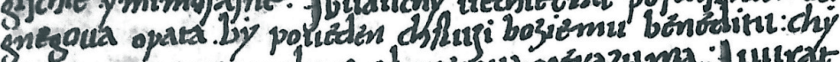

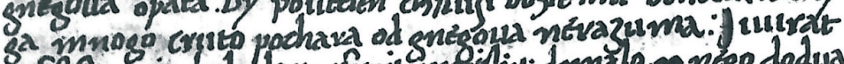

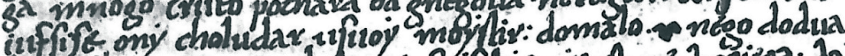

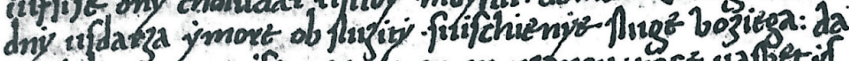

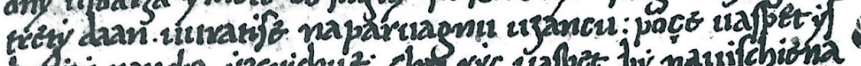

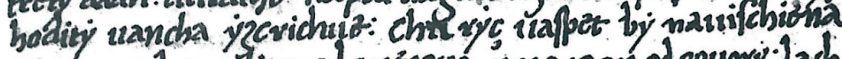

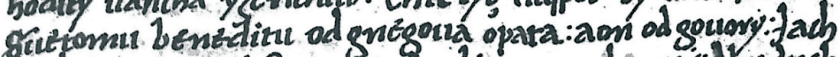

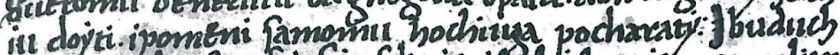

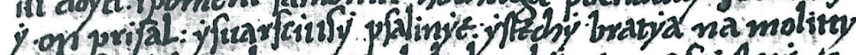

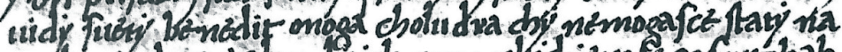

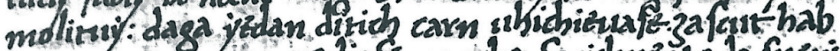

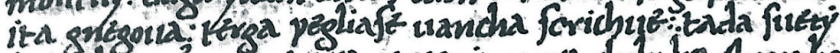
bonedit zatud gnegoun opata: ýmaura choludra Arugur bo

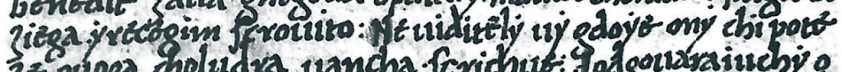

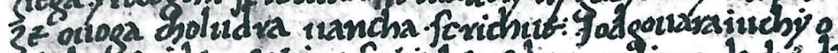

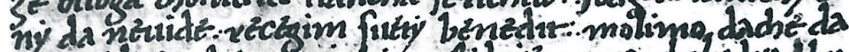

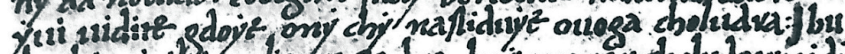

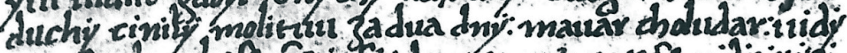

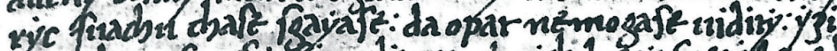

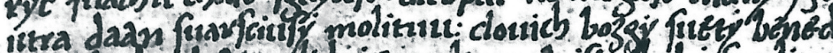

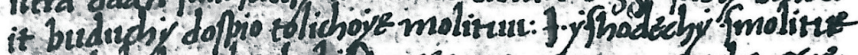

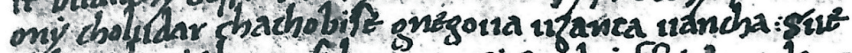

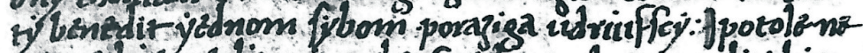

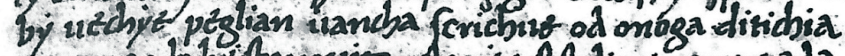

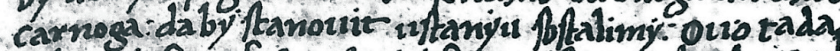

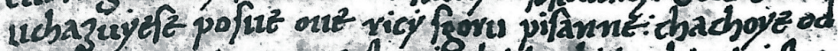

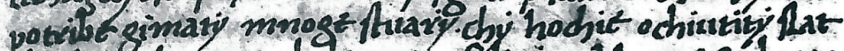

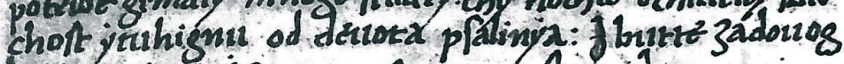
ine out ricy.ja oru farav nallauiboga...... 


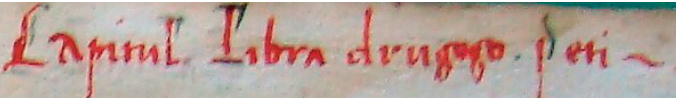

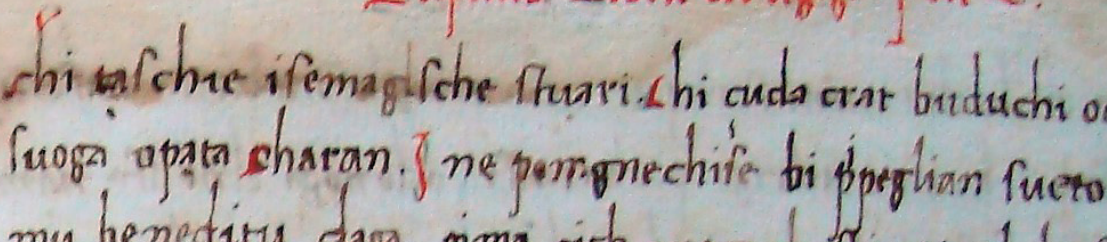

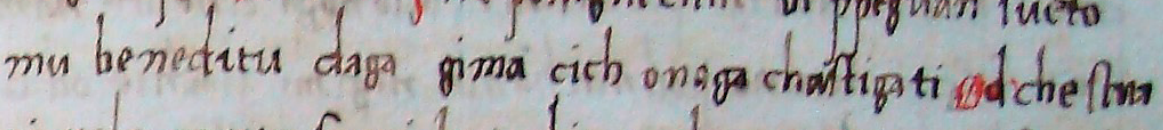

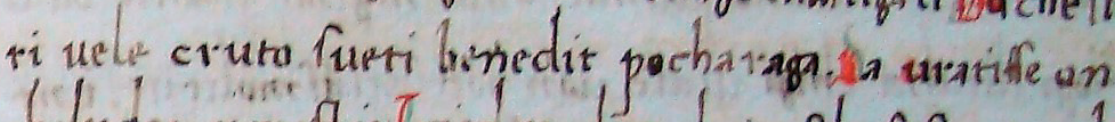

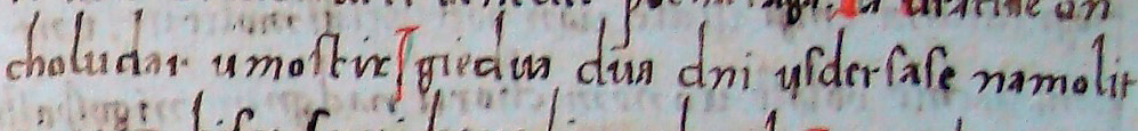
ui exy bifce furti benedit pacharal. Ttretidan oper na fuoin uifancu uratife pridgnu fgredife fimo on me fono urime cho gimare namoliecui fartignathar na dan bi fueromu beneditu na vichiona od oppena

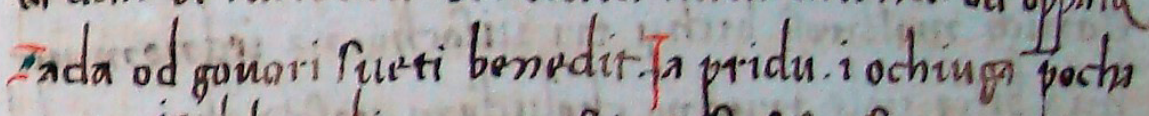

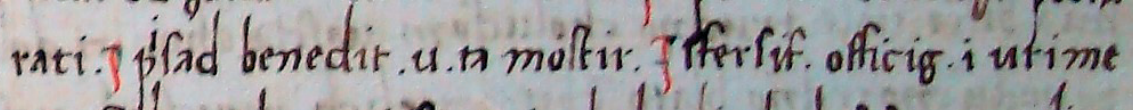

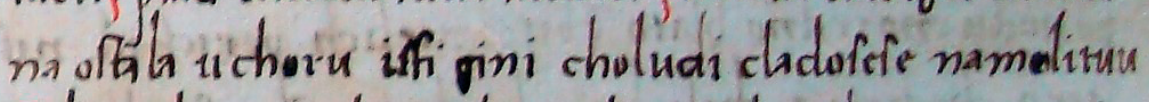

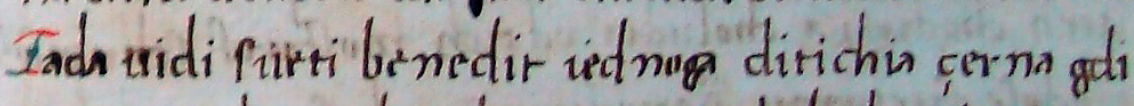
patefe fachirs of fuichgne onoga cholucher chi if mo

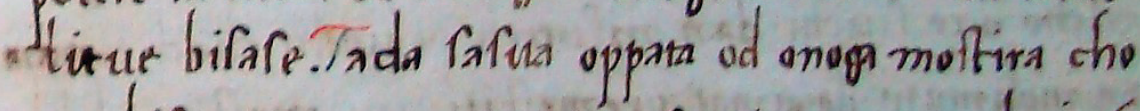
mu bifce gime pomporian i mafra i mnogo pochriuté

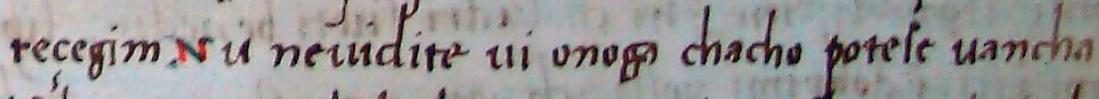
irchora onoge choludra. Toni rechofe clanouiderababe nedit reece Molimu boga dauam dopusti uidiri gdofu onichióm no chuluclar grede upraf. Jucimifi fato du

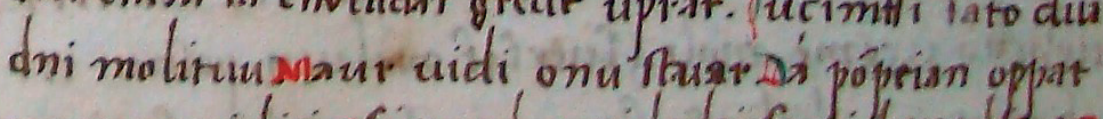

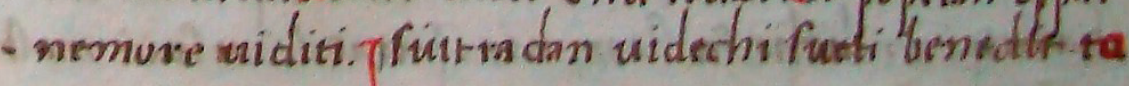

Sl. 12. HS 4 (No 9), f. $47^{\mathrm{r}}$. 


\section{6. >Dubiozni tekstovi` ili prva zbirka hrvatske pučkojezične proze?}

Vidjeli smo da su Marulićev prijevod i ekspozicija Magnificata uklopljeni u Život sv. Ivana Krstitelja koji je opet dio Firentinskog zbornika. Verdiani (1957, 1973) ga je pripisao Marku Maruliću s vrlo uvjerljivim argumentima i metodom kritike teksta kojom se stoljećima koriste sve filologije (klasična, romanistička, germanistička itd.). Njegovi argumenti u Hrvatskoj nisu uopće bili propitivani, analizirani pa onda možda i odbačeni, nego su odbačeni a limine (Malić 1976, Moguš 1976), prije nego što je itko od kritičara uopće vidio taj zbornik ili mikrofilm. Uopće nisu prosuđivali Verdianijeve (1973) argumente, ${ }^{34}$ nego su tematizirali vlastite pretpostavke o Maruliću i rečenom zborniku. Malić (1976: 424) je iznijela u ono doba nerijetko korišten argument o pobožnoj literaturi i pretpostavila nekog »dušobrižnika koludrica « kao autora zbornika, a taj nipošto ne bi mogao biti Marulić:

»Čovjek je srednjovjekovlja okrenut licem prema Bogu, prema ovozemaljskom svijetu odnosi se s prezirom, ne opaža ga. Zato on svoju bit doseže i prakticira (sastavljajući, npr, vjerske kompendije kao što je Firentinskizbornik) obraćajući se Bogu i nezemaljskim bićima, odvajajući se od zbiljskoga prostora vlastite sredine, težeći nebeskim, evanđeoskim prostranstvima. [...] U toj i takvoj književnoj situaciji pojavljuje se Marko Marulić, prvi veliki hrvatski pjesnik. Pod njegovim perom nastaju tekstovi u kojima pjesničke predodžbe sadrže i slike ovozemaljskoga svijeta.«

Moguš (1976) je opet ostao kod strogo statističke metode, iako ni on ne analizira Verdianijeve argumente. Konkordirao je međutim hrvatski leksik Marka Marulića iz »ukupno dvanaest pjesama« i »dva pisma«, dakle tek manji dio, i zaključio da kod njega nema nekih riječi koje se često nalaze $\mathrm{u}$ Firentinskome zborniku, primjerice spoljubljena sestrice`. Stoga, po Mogušu, Marulić nije autor zbornika. On ostaje kod te svoje tvrdnje i onda kada je kasnije uz vlastito izdanje Marulićeva prijevoda Naslidovan'ja (Marulić 1989b: 24) sastavio i čestotni rječnik djela, te pronašao i kao Marulićeve popisao ama baš sve one riječi koje on navodno nije poznavao (usp. Pandžić 2009: 67). Ipak, svoj pogrješni zaključak iz 1976. nije ispravio. Štoviše, tu je

Kako bilježi Nazor (1975: 395) objavljene recenzije bile su priopćene već ranije: »Analize su obavili D. Malić i M. Moguš i rezultate iznijeli na znanstvenom razgovoru o Marku Maruliću, koji je organiziralo Hrvatsko filološko društvo 17. prosinca 1974. na Filozofskom fakultetu u Zagrebu u povodu 450. obljetnice Marulićeve smrti«. 
uznastojao i krnjem, londonskom prijepisu Naslidovan'ja (No 12, R 4903), koji je kao Marulićev prijevod objavio Morović (1971, 1972), osporiti Marulovo autorstvo, iako se

»[...] ne isključuje mogućnost da je i Londonski rukopis nastao na osnovi Marulićeva prijevoda kao prijepis prijepisa, ali se na osnovi podataka kojima je raspolagao Morović to ne bi moglo tvrditi.«

Očevidnu vrlo veliku sličnost dva rukopisa, uglavnom isti poredak riječi, sadržajne i rečenične podudarnosti, najveća je razlika tek u grafijskim uzancama dva prepisivača, Moguš objašnjava na sljedeći način:

»[...] sličnost može biti i plod prijevoda različitih autora na isti jezik u približno isto vrijeme $\mathrm{i}$, zatim, prijepisa s tih različitih predložaka.«

Istom rabulističkom logikom (`mogao je i tko drugi<) do danas se koriste svi, iako malobrojni, negacionistički marulolozi, kojima je glavni cilj osporiti Marulićevo autorstvo njegovih brojnih hrvatskih proznih, dramskih i pjesničkih djela.

Općevažeća formalna i zdravorazumska logika, te empirijski provjerljiva istraživačka metoda u filologiji, u slučaju dva vrlo slična prijepisa Naslidovan ’ja, isto tako i za dvije inačice Života sv. Ivana Krstitelja, postavila bi sljedeće pitanje i smjesta empirijskim putem tražila odgovor: Mogu li danas, dakle u vrijeme stabilnog hrvatskog slovopisa za razliku od Marulova doba, primjerice, dva, tri, četiri, deset ili sto različitih nepovezanih prevoditelja, s latinskoga ili bilo kojeg drugog jezika, na hrvatski prevesti bilo koje tri složene rečenice (dvije plus dugi naslov), sve u šest redaka teksta, tako da barem dva od tih novih prijevoda dobiju isti poredak istih riječi u svih šest redaka? Moguš je, za usporedbu, otkrio tek dva različita slova, ne retka, u incipitima dva prijepisa Naslidovan'ja (londonski i zadarski rukopis). Logički promatrano, empirijski provjerljivo, takvu podudarnost u svih šest redaka neće biti moguće postići ni nakon stotinu ili tisuću pokušaja različitih prevoditelja koji se ne poznaju i ne komuniciraju međusobno. ${ }^{35}$ Kukuljevićev zapis incipita zadarskog primjerka Naslidovan 'ja i incipit londonskog prijepisa podudarni su u dvije rečenice i u naslovu, na njih se odnose Morovićeva i Moguševa argumetacija. Morović je poznavao samo te prve rečenice zadarskoga prijepisa koje je zapisao Kukuljević, cjeloviti zadarski

Kako je Moguš našao tek dva različita »slova « u te prve dvije duge rečenice oba rukopisa, zajedničko podrijetlo londonskoga i zadarskoga prijevoda je neupitno. 
rukopis tek kasnije je pronašao Kulundžić (1976), i zaključio da se mora raditi o prijevodu Marka Maraluća i u londonskom rukopisu jer su se početne rečenice podudarale. I bio je naravno u pravu, a Moguš u krivu. Međutim, i do danas neki hrvatski marulolozi (Malić 2010, Kapetanović 2011), koristeći se njegovom argumentacijskom rabulistikom glede Firentinskoga zbornika (>mogao je i netko drugi - nije dakle Marulić`), drže da su Moguš, naravno i Malić, bili u pravu. Sve to i nakon što su dodatno pobijeni (falsificirani) ama baš svi njihovi argumenti koji bi govorili protivu Verdianijeve atribucije Firentinskog zbornika Marku Maruliću (Pandžić 2009: 50-106).

Malić (2009: 162) se u međuvremenu osvrnula na Verdianijevu i moju argumentaciju, tražeći iznova dokaze protivu Marulićeva autorstva Muke sv. Margarite, prikazanja iz Firentinskoga zbornika, pa je, misleći na moje izlaganje, ne spominjući ime, tvrdila ovako:

»I na ovom skupu [Marulićevi dani 2008] predstavljeno je jedno takvo nastojanje, koje Maruliću pripisuje čitav niz proznih kodeksa, od kojih bar za neke znamo da svojim grafijskim i jezičnim odlikama ne pripadaju splitskom književnom i jezičnom krugu.«

Za koje to "neke« kodekse "pouzdano znamo« da ne pripadaju splitskomu krugu nigdje ne kazuje, ali se iz sljedeće rasprave (Malić 2010) vidi da tu misli na Firentinski zbornik, odnosno ponovo samo na uvodnu dramu iz toga zbornika, Muku svete Margarite, dočim sve druge dijelove toga kodeksa, ${ }^{36}$ kao i ine novootkrivene (Pandžić 2009), uopće ne spominje, niti se osvrće na argumentaciju koju sam iznio protiv njezinih hipoteza. Izgleda da joj je zasmetalo (Malić 2010: 186) da na hrvatske latiničke rukopise »najčešće nailaze strani slavisti i istraživači«. Oni ih dakle ne traže godinama, nego na njih tek tako usput »nailaze«. Potom citira Verdianija (1973: 11), gdje on iskreno veli: »Moram prethodno napomenuti da do tada [1953.] nisam na polju mojih studija imao izravnog dodira s hrvatskom srednjovjekovnom i renesansnom književnošću «. Zbog te rečenice Malić metodom kratkoga spoja slavodobitno zaključuje: »Toliko o strancima «, ${ }^{37}$ pa Verdianijeve dokaze nema potrebe analizirati.

36 Tvrdi tako da u drami nema riječi koje koristi Marulić (plami, kami, poni itd.). Ima ih međutim u drugim dijelovima istoga kodeksa koji su pisani istom rukom, ali te Malić ne kolacionira.

37 Verdiani 1973. govori o otkriću iz 1953. god. Za tih dvadeset godina mogao je on kao školovani filolog o hrvatskoj renesansnoj književnosti ipak ponešto i naučiti, ovo tim prije što mu je poljski bio praktički kao i materinski jezik (u mladosti je došao i godinama ostao u Poljskoj, a živio je jedno vrijeme i u Bugarskoj). Već je ranije pronalazio i opisivao stare slavenske rukopise (Verdia- 
Malić je ovaj put ipak uložila više truda negoli 1976. da bi dokazala kako Muka svete Margarite nije Marulićevo djelo. Rezultat je međutim opet isti, stare pretpostavke postaju novi dokazi. Prema njezinu mišljenju (Malić 2010: 190) postoji velik broj jezičnih detalja u sve tri inačice:

»[...] koji odriču uvrštavanje Muke svete Margarite u Marulićev opus, a pokazuju/ dokazuju njezinu pripadnost hrvatskoj kasnosrednjovjekovnoj anonimnoj književnosti, te starije i sjevernije podrijetlo prvotnoga teksta u odnosu na sačuvane prijepise.«

Metodologijski pak, odnosno jezičnopovijesno promatrano, nemoguće je tri prijepisa Muke svete Margarite koji su nastali u rasponu od barem stotinu godina, anakronistički svesti na jedan zajednički grafijski i(li) glasovni sustav, e da bi onda bilo moguće zaključivati, primjerice, o (ne)provedenoj štokavskoj metatezi $v s^{-}>s v$ - na jugu, sjeveru ili istoku, i - slijedom toga - o dijalektnom i(li) prostornom podrijetlu ove drame, a sve to kako bi se isključilo splitsko podrijetlo i Marulićevo autorstvo. Primjerice, ako i prihvatimo činjenicu da je tzv. šibenska varijanta koju je izdao Fancev $(1925)^{38}$ po nekim slovopisnim karakteristikama šibenskoga (tj. sjevernijega u odnosu na Marulića) podrijetla, kako to hoće Malić, time se može dokazivati samo to da je prepisivač te inačice bio iz šibenskog kraja, ali nipošto i to da je protograf skazanja bio šibenskoga ili kojega drugog "sjevernijeg" podrijetla. Naprotiv, kada se pogleda sadržaj rukopisa XV-44/8 iz Arhiva HAZU, onda se vidi da je taj »šibenski« Život svete Mare (Muka svete Margarite) tu zapisan (f. $13^{\mathrm{v}}-25^{\mathrm{v}}$ ) zajedno s brojnim drugim tekstovima isključivo splitskoga podrijetla, a neposredno, gle čuda, uz pjesmu Karstjanin pita Isukarsta (ff. $12^{\mathrm{r}}-13^{\mathrm{v}}$ ), što je prijevod poznate Marulićeve pjesme Carmen de doctrina D.N.I.C. pendentis in cruce. Zbog pjesama o splitskim svetcima Dujmu, Stašu i Arniru opet, koji se slave u tom kodeksu, kao i zbog drugih pjesama koje nalazimo i u Splitskoj pjesmarici trogirskoga kaptola ${ }^{39}$ Kapetanović i sam zaklju-

ni 1953), a izdao je i nekoliko slavističkih knjiga uključujući i udžbenik staroslavenskoga jezika koji je i danas u uporabi na talijanskim sveučilištima. Zbog svega toga Verdianija je cijenio i Josip Hamm (1978: 3). Taj »stranac« Verdiani je i 1953. i 1973. znao da istražuje rukopis koji je napisan isključivo »hrvatskim« jezikom, da je isti dio »hrvatske renesansne književnosti«, te da se taj jezik i književnost tako zovu najkasnije od Marka Marulića. Njega bi Verdiani najradije nazvao onako kako je sam Marulić nazvao sv. Jeronima u Firentinskom zborniku (f. 24v): »Hyerolim ẏe nas dalmatin. On ẏe dicha i postenẏe slaua i suitlost, chruna haruachoga ẏazicha«.

38 Bila je dugo zagubljena, odnosno, nije ju desetljećima nitko ni tražio. To je učinio tek Krešimir Šimić pa je stoga i pronašao rukopis. Kapetanović (2010a) ga je opisao, ne izvodeći doduše zaključke koji su se time nametnuli i glede izdanja Hrvatskoga srednjovjekovnog pjesništva (2010).

39 Tu pjesmaricu, ali ne samo nju, Vončina uopće nije uzeo u obzir kada je za tisak pripremao Pisni razlike (Marulić 1993, usp. Lučin 2010: 63, bilj. 35). 
čuje (2010a: 190) da je "protograf tog prijepisa morao biti u nekoj užoj vezi sa splitskim krajem (neka splitska pjesmarica)«. I što ćemo sada sa »sjevernijim«, srednjovjekovno-anonimnim podrijetlom Muke sv. Margarite? Jednostavno ga nema. Ništa dakle od "prvotnoga teksta « Muke sv. Margarite nije sjevernije, sve je južnije, sve je splitsko i Marulovo, sve je iz 1500., sve onako kako je za firentinsku inačicu iste drame već odavno utvrdio Verdiani.

Po već spomenutoj rabulističkoj metodi ovdje valja očekivati prigovor: Malić nije mogla znati da je šibenska inačica drame kao i cijela pjesmarica splitskoga podrijetla, jer ju nije vidjela. Ali upravo stoga nije mogla ni zaključiti da ta drama nije Marulićeva nego samo to da je taj prijepis po nekim fonološkim osobinama šibenskoga podrijetla, kao što su to već tvrdili Fancev (1925) i Verdiani $(1957,1973)$. Posljedice su za hrvatsku humanistiku nesagledive. Naime, da je Malić bila izvela jedini znanstveno mogući zaključak, ne bi, zajedno sa svojim suradnicma, istu dramu u sve tri inačice uvrstila u zbirku Hrvatsko srednjovjekovno pjesništvo (Kapetanović i dr. ur. 2010b: 791-865), čime se autoru Marku Maruliću pokušalo ukrasti autorstvo nad jednom od prvih umjetničkih drama hrvatskoga jezika uopće. ${ }^{40}$

Kapetanović (2010b: 792) pak, revnosno slijedeći hipotezu koju je formulirala Malić (2010: 199), nastoji i stihovanoj dataciji (1500) Muke sv. Margarite pri završetku tzv. zadarskog prijepisa, a iz posjeda Bartula Kašića (Pandžić 2009: 107-109), izvrnuti smisao, kako bi se drama i vremenski `odmakla od Marulića, te prebacila u bezdan srednjovjekovne anonimnosti:

$»[\ldots]$ ako jimiste uzmemo u futurskom značenju [...] onda bi navedeni stihovi imali značiti da će oni koji slušaju >ovu muku [...] < imati tisuću i pet stotina godina oprosta grijeha, a oni koji je budu čitali, osigurat će svojoj duši raj «.

Riječ je o stihovima iz rukopisa I a 44, ff. 27v $-28^{\mathrm{r}}$ (usp. Fancev 1932a: 38):

Margarite $\bullet$ diue çiste

chi proschienija $\bullet$ gne gimiste,

lit tisuchia $\bullet$ pet sat visse

ouи muchu •• sui chi slisse,

chiiju stiti $\bullet$ suach dan bude

suoijoij dussi••raij dobude.

$40 \quad$ Slijedeći Verdianija (1973) i Jagića (Marulić 1869), M. Klenovar i S. P. Novak, srećom, te su četiri drame izdali pod imenom autora (Marulić 1986b), a ne kao djela srednjovjekovnih anonimaca. 
Ta je interpretacija púko domišljanje kako bi se Marulića smjestilo u srednji vijek, odnosno, opravdalo uvrštavanje njegovih umjetničkih drama (prikazanja) u srednjovjekovnu anonimnu poeziju:

"A kako se poslije Tridentinskoga koncila uvodi zabrana takvih obećanja, ono bi upućivalo samo na to da je predložak Muke iz Zadarskoga rukopisa nastao u predtridentsko doba, u okviru srednjovjekovnih poimanja.«

Te i slične špekulacije valja odbaciti. Tridentski koncil (1545. - 1563.) nije uopće ukinuo (zabranio) svetu i oprosnu godinu ni same oproste. Ona se do danas slavi svakih četvrt stoljeća i uvijek je povezana s oprostima. Jedino je sadašnji papa Franjo proglasio izvanrednu svetu i oprosnu Godinu milosrđa (8. prosinca 2015. do 20. studenoga 2016.). Svaka je sveta godina naime uz određene uvjete ${ }^{41}$ povezana s potpunim oprostom grijeha za one koji obave proštenje. Stoga ćemo i nadalje znati doslovno razumjeti navedene stihove iz Marulićeve drame Muka sv. Margarite: tko obavi proštenje (obično je crkvu određivao biskup) godine svete 1500. (ljeta tisuću i k tomu još petsto), pretpostavlja se da je obavio i ispovijed, tko bude, $\mathrm{k}$ tome, htio slušati ili čitati dramu u čast sv. Margarite svaki dan (malo ih je znalo čitati), dobit će potpuni oprost, odnoso duši svojoj osigurati raj.

Da je Kapetanović brižljivije, a ne tek selektivno, čitao literaturu o Maruliću, mogao je ovdje poentirati (marulološki big point), znao bi da je Marulić upravo te godine svete 1500. pošao na proštenje u Rim. Napisao je čak i oporuku za slučaj da umre na putu. To bi onda on, Kapetanović, sve smjesta bio povezao s gornjim stihovima, te našao »dokaza« ili barem »čvrstih argumenata«, da nitko drugi od stihotvoraca hrvatskoga jezika te svete 1500. godine nije potegao u Rim nego Marulić, kojemu je ta stihovana datacija kao životna tema i u dramatizaciji očito bila vrlo važna, pa da je on, i zbog tog detalja, najvjerojatnije autor drame Muka sv. Margarite, bez obzira u kojemu prijepisu ona bila. Možda je Marulić čak sam i ishodio taj oprost za čitanje i slušanje svoga prikazanja. A da je Kapetanović pregledao na istom listu malenoga kodeksa (I a 44, f. 28 r), tik iza citiranih, i uvodne stihove u sljedećem proznom Životu sv. Marte (ff. $28^{\mathrm{r}}-31^{\mathrm{r}}$ ),

41 Oduvijek je bila zabranjena i simonija, ali to nisu uzimali u obzir mnogi, posebno oni koji su oprost grijeha pretvorili u trgovinu oprostima (Ablasshandel), što je bio i jedan od uzroka reformacije u Njemačkoj. Protiv takve prakse Crkva je više puta tijekom povijesti intervenirala, dakle ne samo za Tridentinskog koncila (1562), ali prošćenja i oprosti općenito ostali su kao praksa u Crkvi sve do danas. 
prepisane istom rukom, Marulić svoja prozna djela uvijek ukrašava epigramima na početku i(li) svršetku,

Humiglieno prossim $\bullet$ slaunu chripost tuoiu

da pamet diuiçe $\bullet$ prosuitli sad mö̈u.

Neka bude sada ••tuö̈ xiuot umiti

haruaçchi diuiçe • • prauo stumaçiti.«,

zacijelo bi se upitao čiji su to stihovi, čija je to proza. Sigurno bi dao i »relevantnu jezičnostilsku analizu « epigrama i tumačenje zašto u jednom zadarskom rukopisu toga doba stoji haruaçchi, a ne heruaçchi, itd.

Umjesto toga Kapetanović (2011: 7) je uznastojao u nekoliko bilježaka (Fußnoten) pobiti argumente koje sam iznio u prilog Marulićeva autorstva $\mathrm{R}$ 6634 (No 21), ali se ne osvrće na atribucije brojnih inih, donedavno anonimnih rukopisa (Pandžić 2009). Od više dokaza glede toga rukopisa on osporava samo jedan:

»Nedavno se pokušalo navesti marulologiju na stari put paušalnih atribucija poradi >epohalnih otkrića Marulićevih tekstova, pa se i latinični zbornik koji je ovdje u žarištu našega zanimanja [No 21, R 6634] našao na popisu zbornika koji se pripisuju Maruliću, premda nije ponuđena relevantna jezičnostilska analiza dubioznih tekstova. Pripisivač citira Bajamontijeve riječi o tom rukopisu, među kojima su najvažnije: ‘rukopis, koji sadržava neke pjesme Marka Marulića [...] alcune poesie illiriche del' Marulo [...] $<. \ll^{42}$

Doista, pokušalo se, ali ne "navesti marulologiju« na bilo što, nego tragati za onim o čemu je Jagić još 1869. zborio, tj. »da će se danas sutra i u prozi naći više hrvatskih djela Marulićevih, nego li za koja danas znamo«. Tražilo se stoga po cijeloj Europi realne hrvatske rukopise - nipošto ideološki ili inčije dubiozne - nastale za života Marka Marulića u Splitu. I našlo se dosta toga, to je čitava zbirka, zapravo prva biblioteka hrvatske pučkojezične proze uopće, ako ovdje po strani ostavimo molitvenike i lekcionare. Samo zbog te činjenice, tj. i kada

42 U bilješci (9) dodaje: „Napominjem da u izvorniku stoji di, a ne del' (usp. sliku broj 6 u Pandžićevoj knjizi)«. Netočno. Slika 6 je preslika jednoga od dva Bajamontijeva zapisa o spomenutom rukopisu, koji na str. 29 citiram u prijevodu Ivana Milčetića (1912), ali ne i u talijanskom prijepisu, jednostavno ga nisam htio dva puta donijeti na talijanskom. Tek u daljnjem tekstu, tj. u drugom Bajamontijevu svjedočanstvu o Marulićevu rukopisu No 21, taj nije preslikan, citirao sam ga prema Beriću (1950), nalazi se del' dva puta. Kapetanoviću se dakle samo pričinio pogrješan citat. 
bismo posve zanemarili ime Marka Marulića, svaki bi se student kroatistike, a da ne govorimo o jezikoslovcima i akademicima, smjesta priupitao: Tko je to zapravo rodonačelnik hrvatske pučkojezične umjetničke proze? Usudio sam se kao >stranac $<$ ustvrditi, nasuprot samoreferencijalno zatvorenoj »hrvatskoj marulologiji« koja Marulićeva hrvatska književna djela svrstava u srednjovjekovnu poeziju i starohrvatski jezik (Kapetanović i dr. 2010b, Štrkalj Despot 2011), da je to isti onaj muž koji je, uz neke pjesme i dramski pokušaj Džore Držića, rodonačelnik i hrvatske umjetničke poezije, i epike, i dramatike, i egzegeze itd., sve to opet narodnoga, tj. novohrvatskoga jezika (hrvatskoga volgare illustre).

Što se pak Julija Bajamontija (1744. - 1800.) tiče, Kapetanović uopće ne razumije što je poenta argumentacije. Ne poričem da je Šime Jurić opisujući rukopis R 6634 prije mene naveo i staru signaturu No 21 tog rukopisa, niti da je Verdiani (1957: 66) preslikao staru signaturu No 1 Firentinskog zbornika, dapače, Verdianijeva me je preslika i navela na pravi trag. Međutim, pronašao sam u literaturi i podatak (Milčetić 1912), to je ovdje bitno, da je Bajamonti još u 18. st. ista ta dva rukopisa (No 1 i No 21 ) vidio i bez ikakve zadrške tvrdio da oba sadrže Marulove poezije. ${ }^{43}$ Dakle, nakon obavljene autopsije povezao sam rukopise koje je Splićanin Bajamonti poznavao kao Marulićeve, zapisavši čak i signature kodeksâ crvenom tintom ( No 1 i No 21), te ih identificirao kao današnje rukopise iz Zagreba i Firence, što nitko prije nije učinio, dakle ni Jurić ni Verdiani, ni bilo tko drugi. Maruliću je ta dva rukopisa pripisao još prije 250 godina splitski polihistor Bajamonti, što je jedinstven argument $i$ za Marulićevo autorstvo i za Verdianijevu atribuciju. $\mathrm{U}$ tomu je poenta moga nalaza.

Radi provjere Bajamontijevih citata (Milčetić 1912, Berić 1950) naručio sam i snimke iz Arheološkog muzeja u Splitu (Branko Jozić mi ih spremio). Doista, Splićanin Bajamonti je kao učen čovjek, liječnik, pisac i glazbenik, vrlo dobro znao tko je bio Marulić i što je pisao, stoga je i pouzdan svjedok; prepoznao je Marulićevu poeziju u rukopisima (No 1 i No 21 ) i to zabilježio. Oba sadrže, prema njemu, neke poezije Marka Marula, zapisao je da je i sam posjedovao neke Marulove rukopise u svojoj kući prije požara. Neko drugo ime Bajamonti ne spominje u svezi s tim rukopisima. Oba rečena je jedna te ista ruka na praznim

Vidio ih je kod Capogrossa i(li) Danielija. Obje su obitelji bile povezane s Marulićem, a pustinjak s Marjana Rugiero Capogrosso trebao je po Marulovoj želji voditi i obred njegova pokopa u crkvi sv. Frane na obali. Iz tih obitelji bilo je više koludrica u samostanima benediktinki sv. Arnira u Splitu, gdje je živjela i Marulova sestra Bira, i u Zadru, u samostanu sv. Marije, gdje su rukopisi najkasnije po ukinuću samostana u Splitu, za Napoleona, bili prebačeni. 
listovima i nadopisivala (usp. Pandžić 2009: sl. 9ab), nekoć su dakle bili zajedno u jednoj zbirci. Imaju i jedan zajednički vodeni znak papira (filigran), što sam tek nedavno utvrdio.

Naravno, Bajamonti je znao da to nisu sve Marulove poezije nego tek neke (alcune), osobno je, bilježi dalje, posjedovao i neke druge njegove rukopise. Kapetanović se sada domišlja i tvrdi da je Bajamonti možda htio reći da ti rukopisi sadrže »samo neke " Marulove poezije, pa bi onda teoretski njegove mogle biti i samo dvije pjesme. To je ista ona `marulološka rabulistika< o kojoj je ovdje već bilo riječi, jer Bajamonti nigdje nema »samo« (soltanto, solamente ili sl.), a kada govori o ta dva onda spominje i ine Marulove rukopise koje je nekoć posjedovao, opet ničije druge. Još jednom, kako bi se izbjeglo novo izvrtanje smisla: oba rukopisa je Maruliću - i nikomu drugomu - pripisao splitski polihistor Julije Bajamonti još u 18. st. On je do danas najstariji poznati svjedok o autorstvu ta dva Marulićeva kodeksa. Kapetanovićev "pripisivač« iz 21. st. je pročitao i ozbiljno shvatio splitsku atribuciju iz 18. st., te tražio rukopise o kojima govori Bajamonti, pronašao ih je u Firenzi i Zagrebu (No 1 i No 21). Nakon toga je pretpostavio da između 1 i 21 (isti je pisoruk i oblik starih signaturâ) ima još 19 njih, odnosno da je bilo još toliko rukopisâ na istoj polici ili u istoj škrinji, i počeo je za njima tragati. No 12 , tj. ^londonski< prijepis Naslidovan 'ja već mu je bio poznat kao treći, dokazano Marulićev, rukopis iz te zbirke. Neke je na tom tragu već našao, za inima i danas traga.

Međutim, važno je za argumentaciju ovdje, zbog budućeg istraživanja i izdavanja Marulićevih hrvatskih djela, pokazati da je pitanje ispravne jezičnopovijesne, kodikološke i (paleo)grafijske analize odlučujuće za bilo koju atribuciju povijesnih rukopisa. Kapetanović uopće ne argumentira u smislu te metode, a kamoli u smislu već izložene povijesne kritike teksta (duplex theoria), pa se (i) njegovim anakronističkim i selektivnim pristupom (Kurzschlussmethode) niti što može dokazati niti što osporiti glede Marulićevih tekstova. Naime, samo sinoptika sinkronih rukopisa može pokazati jesu li ispitivani tekstovi (kodeksi) po uzancama pisarâ i pisarske škole (pisanje pojedinih slova i njihove glasovne vrijednosti) afini ili ne, odnosno je li se u Splitu tako pisalo i izgovaralo za života Marka Marulića ili ne. Nasuprot tomu, Kapetanović je (2011: 13) neke tipizacije čakavskih mikrodijalekata, nastale na osnovu terenskih istraživanja u 20. stoljeću, jednostavno projicirao 500 godina unazad pa je na taj način ad hoc identificirao i popisao » 6 karakterističnih fonološko-morfoloških kriterija za utvrđivanje južnočakavske podloge tekstova književnika splitskoga kruga«. Pri tomu su 
mu najvažniji ikavski refleks jata, izostanak priloga/ veznika kadi i provedena metateza $v s$ - $>s \mathcal{v}$-, a manje važni neka miješanja uporabe akuzativa, instrumentala i lokativa i sl. Začudo, za potkrijepiti tu tezu on ne traži prozu i poeziju datiranu za Marulićeva života, nego samo kasniju poeziju (str. 12): »Sačuvanih tekstova pjesnika iz Marulićeva pjesničkoga kruga nema mnogo, ali poznajemo po jednu pjesmu četvorice Marulićevih suvremenika i sugrađana [...]«. One su, međutim, sačuvane u Vartalu s konca 16. st. Riječ je dakle o slovopisu i fonopisu Petra Lucića, a ne Marka Marulića i njegovih suvremenika.

Uopće ne spominje datirane splitske prozne rukopise, u njima ima i poezije, pa čak ni već objavljenu Hrvatsku prozu Marulićeva vremena (Hamm 1978, 1987). Ti bi rukopisi već u startu demantirali u to doba navodno već provedenu metatezu $v s$ - $>s v$ - na splitskome području. Ta je proza (1513. i 1514.), bez ikakve sumnje, daleko bolji indikator grafijske i jezične slike općenito u Splitu Marulićeva doba od nekih prijepisa koji su nastali 80 godina kasnije u Trogiru. Ili je Kapetanović možda mislio da »karakteristična jezična obilježja« vrijede jedna za prozu, a druga za poeziju? Sve u svemu, žanrovska redukcija (samo poezija, tek pedesetak stihova) i anakronistička tekstualna podloga (četiri pjesme zapisane tek koncem 16. st.), nemaju nikakve ili imaju tek vrlo malo, ali posve netipične veze sa slovopisom i fonopisom hrvatskih djela Marka Marulića. Koje su to jezične osobine vrijedile na "južnočakavskom području«, u inoj terminologiji je to istočnočakavsko područje, za života Marka Marulića, čitatelj ni od Kapetanovića ni od Malić uopće ne može saznati.

Nasuprot tomu, ovdje navodim i slovopisno uspoređujem (u sinopsi naniže) samo rukopise koji su točno ili približno datirani još za života Marulova, a svakako su podrijetlom iz Splita (usp. Pandžić 2009: 107-137): No1 (Ashb. 1582, tj. Firentinski zbornik). No3 (HS 5, Cvitje), nedatiran, ali po filigranima (1507, 1519) negdje oko 1520. (usp. Hamm 1987: 37 ), No3 (HS 6, Od rasutja jerosolimskoga) iz 1513., $\mathbf{N}^{\circ} \mathbf{6}$ (Add. 10394, Upute za dobar život redovnicama) iz 1514., No 9 (HS 4, Dijalozi Grgura Velikoga) iz 1513., No 11, Add. 10625, Govorenja suerhu vecere, također 1513., No 13 (R 6633 iz 1508., Zardin od molitve), te najstariji od svih (oko 1500.) umetak iz Vartala (IV a 31, ff. 220 ${ }^{\mathrm{r}}-265^{\mathrm{r}}$ ). U njemu ima dosta i poezije, blizu 2000 stihova s početka 16. st., nasuprot pedesetak stihova u četiri pjesme s konca 16. st. koje Kapetanović uzima kao smjerodavne pri određivanju jezičnih karekteristika na »južnočakavskom području u u Marulićevo vrijeme. Kodeksi No 12 (R 4903), No 14 (R 3662), No 16 (Add. 10395) i 
No 21 (R 6634) su prijepisi nastali nakon Marulove smrti (1524), pa ih ovdje za pojasniti slovopisne uzance za njegova života ne kolacioniram.

Manje je važno da ti splitski rukopisi često u određenim osnovama (děl-, těl-, věr- itd.) imaju ekavski ili pomiješani refleks jata, te da nema ni govora o tome da je u Splitu u Marulićevo vrijeme bila dosljedno provedena štokavska metateza $v s->s v-,{ }^{44}$ kako bi to htio Kapetanović, daleko je važnije, barem za našu argumentaciju ovdje, da svi ti rukopisi, izuzev sitnih odstupanja u No 11 (Govorenja suerhu vecere i Acta Pilati) koriste praktički isti slovopis i fonopis, odnosno da je njihovo splitsko podrijetlo i Marulićevo vrijeme neupitno. Kolacioniranje s Juditom pokazuje sličnost slovopisa, ali i redukciju slovopisnih inačica $u$ tipografiji epa.

Jedan od tih rukopisa je i Cvitje (No3), koji je objavio Hamm (1987), a neke lingvističke osobine analizirao je i Muljačić (1995: 97-111). On je dobro poznavao i opisivao sličnu problematiku povijesne dijalektologije talijanskoga i inih romanskih jezika, pa je jasno formulirao što bi to bila ispravna metoda pisanja priloga za povijesnu dijalektnu tipizaciju čakavskoga, koji bi onda u sumi služili za izradbu čakavskoga povijesnog rječnika (str. 100sl.):

»Tko se bude odvažio da napiše Čakavski dijalekatni [...] rječnik (o čemu postoje različite koncepcije), trebao bi, po mom mišljenju, da raspolaže $s$ radovima izrađenima po načelu od manjega prema većemu. Logički bi slijed bio:

1. sinkronijski opis leksika jedne čakavske koine u jednom određenom razdoblju;

2. sinkronijski opis leksika svih čakavskih koine u istom razdoblju;

3. i 4. analogno za sve pojedine čakavske koine u ostalim sinkronijskim razinama;

5. povijesni čakavski rječnik. Tek kad budemo raspolagali bitnim dijelovima ovog ambicioznog plana, moći ćemo, uz pomoć lingvističkog

$44 \mathrm{U}$ stvari $s v$ - i $v s$ - u splitskim rukopisima nalazimo promiscue, većinom $v s$ - kod Markovih pisara, dočim on sam ima pretežito štokavsku metatezu $s v$-. Malić (2010: 196) doduše tvrdi da se u firentinskoj verziji skazanja Muka svete Margarite nalaze još samo »pojedinačni ostaci« starijega oblika ove suglasničke skupine (vsakomu, vsih, vsu, vse), ali ipak »redovito pridjevi vsemogi i vsemogući [...], vsemogoga Gospodina [...], Isukarsta vsemogoga [...], vsemogući o Isuse«, što je autor koristio navodno »kao fonostilem «. Po mome brojanju otprilike jedna polovica svih primjera te suglasničke skupine je u Firentinskome zborniku zapisana kao $s v$ - a druga polovica $v s$ - $\left(f_{s-}\right)$. 
atlasa našeg jezika (barem u današnjem stanju), praviti horizontalne, vertikalne, transverzalne i poredbene analize, na pr. proučavati uzajamne odnose između čakavskoga i susjednih jezičnih sustava."

Nije mi poznato jesu li dijalektolozi čakavskoga u međuvremenu slijedili ovu općepriznatu metodu povijesne dijalektologije, ali sve upućuje na to da se uređivački odbor Sabranih djela Marka Marulića njome nije ni bavio, pa je, izgleda, slijedeći Malić, stao uz suprotnu metodu, tj. »od većega prema manjemu«, od današnjega stanja prema dobu Marka Marulića. Dakle, ako neki tekst nije napisan na istočnočakavskoj dijalektnoj koine, koja je opet definirana prema stanju na terenu u 20. st., onda taj tekst i ne može biti Marulićev. Slijedom toga, jer se takvom anakronističkom, nasuprot jezičnopovijesnoj sinkronoj metodi, u filologiji ne može ništa ni dokazati ni osporiti u svezi s hrvatskim djelima Marka Marulića, izgleda da se neće ništa ni mijenjati u sadržaju SDMM-a, odnosno njegovih hrvatskih proznih djelâ. Kapetanovićevi »dubiozni tekstovi«, tj. prva zbirka splitske i hrvatske pučkojezične proze uopće, ostaje tako isključena iz Marulova opusa, tj. barem u formatu SDMM-a.

Moguće je ipak da se tu nešto i promijeni. U međuvremenu se naime Malić (2011: 78) predomislila, sada tvrdi da dva osmeračka prikazanja iz najstarijega dijela Vartala, Govorenje svetoga Bernarda od duše osujene (ff. $\left.220^{\mathrm{r}}-232^{\mathrm{v}}\right)^{45}$ i Skazanje od nevoljnoga dne od suda ognjenoga (ff. 232 ${ }^{\mathrm{v}}-254^{\mathrm{r}}$ ), »najvjerojatnije jesu Marulićeva«. Ne kaže ništa o Marulićevu autorstvu Života sv. Ivana Krstitelja (ff. $\left.255^{\mathrm{r}}-268^{\mathrm{r}}\right)$ iz istoga dijela Vartala, pisana istom rukom kao i ta dva skazanja. Isti se Život u široj inačici, proširenje je u biti dodana Marulićeva ekspozicija $M a$ gnificata, nalazi i u Firentinskom zborniku. Obje inačice sadrže Marulićev prepjev Magnificata kao i dijelove Prikazan'ja historije sv. Panuncija, također njegova djela. U Firentinskom je zborniku i prikazanje Muke svete Margerite, kojoj je Marulićevo autorstvo Malić inače 40 godina osporavala. U njemu na koncu krvnik Cocan odrubljuje glavu sv. Margariti, isti onaj Cocan koji odsiječe glavu i sv. Ivanu Krstitelju u Životu. Očito je isti i autor sva četiri prikazanja kao i Života sv. Ivana Krstitelja. Malić se dakle, doduše ne izrijekom, ali ipak de facto, možda i nehotice, na koncu svrstala u krug onih koji su već odavno tvrdili (Verdiani,

45 Krnji oblik toga prikazanja nalazimo i među Marulićevim hrvatskim pjesmama i žićima u dubrovačkom rukopisu 589 (Pandžić 2009: 138-141), a cjeloviti u I b 55, ff. 105 -122v' koji je Jagić koristio za izdanje Marulićeve (1869) poezije. Tu je zapisan kao dodatak uz Marulićev prijevod pseudo-Bernardova Liber de modo bene vivendi, ad sororem. 
Badalić, Štefanić, Kolumbić, Kulundžić, Novak, Hamm itd. $)^{46}$ da su najstariji dio Vartala i Firentinski zbornik djelo Marka Marulića. Prema Badaliću (1957) radi se u sva ta tri teksta iz Vartala i o Marulićevu pisoruku, što sam mogao potvrditi (Pandžić 2009) nakon atribucije rukopisa No 13 (R 6633 iz 1508.), koji je istoga pisoruka i slovopisa kao i najstariji dio Vartala. Kodikološki, slovopisni, leksički i sadržajni intra- i intertekstualni tepih istkan ovdje, prije svega na temelju istraživanja rukopisa No 1 iz Firence (nekoć Splita i Zadra) i Vartala (IV a 31) iz Zagreba (nekoć Splita i Trogira), s analizom Marulove ekspozicije Magnificata u čvorištu, dovodi do zaključka da je Marko Marulić autor tih rukopisnih djela. A kada se bude spremalo novo, kritičko izdanje Firentinskoga zbornika i četiri dramska Marulićeva djela (usp. Marulić 1986b, Lučin 2017), lako će se onda, između ostaloga, moći pojasniti zašto i najstariji zapisani stihovi Marulova Prikazan'ja historije sv. Panuncija potječu upravo iz ta dva rukopisa.

\section{Slovopis Judite i najstarijih splitskih pučkojezičnih kodeksa}

Slijedi najavljena sinopsa i kratki komentar grafijskih osobina splitskih rukopisâ Marulićeva doba i autorstva, te tiskane Judite (1521). Kodeksi No 12, No 14, No 16 i No 21 su prijepisi nastali nakon Marulove smrti 1524., pa se ovdje ne kolacioniraju, iako je i tu Marulovo autorstvo, izuzev, zasada, kodeksa No 16, neupitno.

$46 \quad$ Upadljivo je da su svi oni imali iskustva s kodikološkim istraživanjima, pa su vjerojatno stoga i naginjali Verdianijevoj atribuciji Firentinskog zbornika Marku Maruliću, dočim Malić, Moguš i Kapetanović taj zbornik uopće nisu ni pokušali pregledati, a kamoli sustavno analizirati. Ipak, njihovo je mišljenje prihvaćeno u uređivačkom odboru SDMM-a. 


\begin{tabular}{|c|c|c|c|c|c|c|c|c|c|}
\hline $\begin{array}{l}\text { Fo- } \\
\text { ne- } \\
\text { mi }\end{array}$ & $\begin{array}{l}\text { Vartal } \\
\text { IV a } 31 \\
\text { o. } 1500 . \\
\end{array}$ & \begin{tabular}{|l} 
Firent. \\
zbornik \\
No $\mathbf{1}$ \\
o. 1510. \\
\end{tabular} & $\begin{array}{l}\text { Zardin } \\
\text { No } 13 \\
1508 . \\
\end{array}$ & $\begin{array}{l}\text { Od } \\
\text { rasutja } \\
\text { No } 3 \\
1513 . \\
\end{array}$ & $\begin{array}{l}\text { Acta } \\
\text { Pilati } \\
\text { No } \mathbf{1} 1 \\
1513 . \\
\end{array}$ & $\begin{array}{l}\text { Dija- } \\
\text { lozi } \\
\text { No } 9 \\
1513 .\end{array}$ & $\begin{array}{l}\text { Institu- } \\
\text { cija } \\
\text { No } \mathbf{6} \\
1514 . \\
\end{array}$ & $\begin{array}{l}\text { Cvitje } \\
\text { No } 3 \\
1520 . \\
\end{array}$ & Judita \\
\hline c & $c$ & $c$ & $c, c ̧$ & $c, c ̧$ & $c, c ̧$ & $c, c ̧$ & $c, c ̧$ & $c, c ̧$ & c \\
\hline$\check{c}$ & $c, c ̧$ & $c ̧$ & $c, c ̧$ & $c ̧, c$ & $c ̧, c$ & $c ̧, c$ & $c ̧, c$ & $c ̧, c$ & c \\
\hline ć & $\mathrm{ch}^{47} \mathrm{ty்}, \mathrm{ti}$ & h, ch & ch,ty்,ti & $\mathrm{ch}$ & $\mathrm{ch}$ & ch & $\mathrm{ch}$ & $\mathrm{ch}$ & ch \\
\hline i & $\mathrm{i}, \dot{\mathrm{y}}, \mathrm{j}$ & $\mathrm{i}, \mathrm{j}, \dot{\mathrm{y}}$ & $\mathrm{i}, \dot{\mathrm{y}}, \mathrm{j}$ & $i, \dot{y}, j$ & $i, j$ & $i, \dot{y}, j$ & $i, \dot{y}, j$ & $\mathrm{i}, \ddot{\mathrm{y}}^{48}$ & i (y) \\
\hline $\mathbf{j}$ & $\dot{\mathrm{y}}, \mathrm{g}, \mathrm{j}, \mathrm{i}, \varnothing$ & $\dot{y}, g, j^{49} \varnothing$ & $\dot{y}, \mathrm{~g}, \mathrm{j}, \mathrm{i} \emptyset$ & $\dot{\mathrm{y}}, \mathrm{g}, \mathrm{j}, \mathrm{i}, \varnothing$ & $g, j, i, \dot{y}$ & $\dot{y}, g, i, j \emptyset$ & $\dot{\mathrm{y}}, \mathrm{g}, \mathrm{j}, \mathrm{i} \varnothing$ & $\ddot{\mathrm{y}}, \mathrm{g}, \mathrm{i}, \varnothing$ & $i, g, \varnothing$ \\
\hline $\mathbf{k}$ & ch,c & $\begin{array}{ll}\mathrm{ch}, \mathrm{c} \\
\end{array}$ & ch,c & $\mathrm{ch}, \mathrm{c}$ & $\mathrm{ch}, \mathrm{c}$ & $\mathrm{ch}, \mathrm{c}$ & $\mathrm{ch}, \mathrm{c}$ & ch,c & $\operatorname{ch}(\mathrm{c})$ \\
\hline 1 & gl, 1 & gl,l & gl,l & gl,l & gl,l & gl,l & gl,1 & gl,l & gl,l \\
\hline l'j & lỳ, li & lỳ, li & lỳ, li & lỳ, li & li & lỳ, li & lỳ, li & lÿ,li & li \\
\hline ń & gn & gn & gn & gn & gn & gn & gn & gn & gn \\
\hline $\mathbf{n}^{\prime} \mathbf{j}$ & ny், ni & ny், ni & ný, ni & ný, ni & ni & ny், ni & ny், ni & ni, nÿ & ni (ny) \\
\hline$s$ & $\mathrm{~s}, \mathrm{f}$ & $\mathrm{s}, \mathrm{f}, \mathrm{z}$ & $\mathrm{s}, \mathrm{f}$ & $s, 1$ & $\mathrm{~s}, \mathrm{f}$ & $\mathrm{s}, \mathrm{f}$ & $s, f$ & $\mathrm{~s}, \mathrm{f}$ & $f, s$ \\
\hline$\check{\mathbf{s}}$ & $\mathrm{s}, \mathrm{f}$ & ss,s & $s c, f c, s, f$ & $s c, f c, s$ & $\mathrm{sc}, \mathrm{fc}, \mathrm{s}, \mathrm{f}$ & $\mathrm{sc}, \mathrm{fc}, \mathrm{s}$ & $\begin{array}{l}\mathrm{sc}, \mathrm{fc}, \\
\mathrm{s}, \mathrm{f}\end{array}$ & $s c, f c, s$ & fc,, , s \\
\hline $\mathbf{u}$ & $\mathrm{u}, \mathrm{V}$ & $\mathrm{u}, \mathrm{V}$ & $\mathrm{u}, \mathrm{V}$ & $\mathrm{u}, \mathrm{V}$ & $\mathrm{u}, \mathrm{V}$ & $\mathrm{u}, \mathrm{V}$ & $\mathrm{u}, \mathrm{V}$ & $\mathrm{u}, \mathrm{V}$ & $\mathrm{u}, \mathrm{V}$ \\
\hline $\mathbf{v}$ & $\mathrm{u}, \mathrm{uu}, \mathrm{V}, \mathrm{f}$ & $\begin{array}{l}\text { uu,u, } \\
\mathrm{V}, \mathrm{f}\end{array}$ & $\begin{array}{l}\mathrm{u}, \mathrm{uu}, \\
\mathrm{V}, \mathrm{f}\end{array}$ & $\mathrm{u}, \mathrm{u}, \mathrm{V}, \mathrm{f}$ & $\begin{array}{l}\text { u,uu, } \\
\mathrm{V}, \mathrm{f}\end{array}$ & $\begin{array}{l}\text { u,uu, } \\
\mathrm{V}, \mathrm{f}\end{array}$ & $\begin{array}{l}\text { u,uu, } \\
\text { V,f }\end{array}$ & $\begin{array}{l}\text { u,uu } \\
\mathrm{V}, \mathrm{f}\end{array}$ & $\begin{array}{l}\text { u,uu } \\
\text { V,f }\end{array}$ \\
\hline$z$ & $z, s, f$ & $s, f, z$ & $\mathrm{z}, \mathrm{s}, \mathrm{f}$ & $\mathrm{z}, \mathrm{s}, \mathrm{f}$ & $\mathrm{z}, \mathrm{s}, \mathrm{f}$ & $\mathrm{z}, \mathrm{s}, \mathrm{f}$ & $\mathrm{z}, \mathrm{s}, \mathrm{f}$ & $\mathrm{z}, \mathrm{s}, \mathrm{f}$ & $z, 1$ \\
\hline$\check{\mathbf{z}}$ & $\mathrm{z}, \mathrm{s}, \mathrm{x}^{50}$ & $\mathrm{~s}, \mathrm{X}, \mathrm{ss}, \mathrm{Z}$ & $\mathrm{Z}, \mathrm{s}, \mathrm{X}$ & $\mathrm{z}, \mathrm{s}, \mathrm{f}, \mathrm{x}$ & $\mathrm{x}, \mathrm{z}, \mathrm{s}, \mathrm{f}$ & $\mathrm{z}, \mathrm{s}, \mathrm{f}$ & $z, s, f$ & $\mathrm{z}, \mathrm{s}, \mathrm{f}$ & $\mathrm{z}, \mathrm{s}$ \\
\hline
\end{tabular}

Ortografiju Judite opisao je Maretić (1889: 11-14), a usporedbu s umetkom iz Vartala priopćio Mladenović (1959). Judita je u slovopisnom smislu pojednostavljena, to je tražila i tipografija, neki dubleti su izbačeni, tako ona više nema $\dot{y}$ (ipsilon s točkom) za /j/ i(li) /i/. Ipsilon je vrlo rijedak u Acta Pilati (No 11, iz 1513), iako ga češće ima od njega ovisni rukopis Od rasutja jerosolimskoga (No 3, također iz 1513). Inače, svi uspoređeni rukopisi kao i Judita poznaju i pisanje $g$ za /j/. Razlike su uglavnom u čestoti pisanja pojedinih znakova. Najveći posto-

47 Uz ch u svim rukopisima nalazi se često i chi (analogno $g l$, gli) kada slijedi suglasnik ili samoglasnik gdje bi se $c h$ moglo pogrješno čitati kao /k/. Pisanje ty், $t i / c ́ /$ češće se nalazi u Vartalu $i$ Zardinu (Marulovi autografi), u drugim kodeksima vrlo rijetko.

$48 \mathrm{U}$ Cvitje se znak ÿ piše s dvije točkice, vrlo rijetko s jednom, tako je onda u kasnijim kodeksima (R 6634). I po tom znaku vidimo da je Cvitje najmlađi rukopis ovdje.

49 U Firentinskom zborniku se $\mathrm{j}$ i u minuskuli javlja često, u drugim rukopisima općenito rijetko, češće ipak u majuskuli.

50 U Govorenje svetoga Bernarda od duše osujene, tj. u prvom po redu, pa stoga i najstarijem od tri djela iz Vartala (f. 220r-232v) pisana jednom rukom, za /̌̌l je 25 puta zapisano x (Mladenović 1959: 121), u Juditi samo jednom, češće u Firentinskom zborniku, vrlo rijetko u Zardinu. Opći je dojam da se x gubi s vremenskim odmakom od Lekcionara Bernardina Splićanina (1495), iako su taj znak svi pisari barem poznavali. 
tak pisanja $\dot{y}$ za /j/ i(li) /i/, te $g$ za /j/ imaju dva najstarija rukopisa, tj. umetak iz Vartala (o. 1500) i Zardin iz 1508., dočim ih Firentinski zbornik nešto rjeđe koristi, ali ipak u oko trećine primjera. U svakom slučaju svi rukopisi su usporedive, afine, čak monogene grafije, uz posve normalna odstupanja po čestoti uporabe znakova, a po pisanju jedinstvenoga $\dot{y}$ s točkom za /j/ i(li) /i/ (hrvatska latinična grafija taj znak ne poznaje nakon Marulove smrti), $g$ za /j/ i sl., zaključujemo da se tu radi o jedinstvenoj (orto)grafiji koju je koristio Marulić u Vartalu i Zardinu, uz tipografijsko pojednostavljenje u tiskanoj Juditi. Pisari su uglavnom slijedili njegove uzance zadržavajući i neke vlastite oblike. Isto vrijedi za grafiju /ć/, uz ch samo u ta dva kodeksa češće nalazimo i ty், ti.

Posebno je zanimljivo pisanje glasa /v/. Redovno se po latinskom običaju i za /u/ i za /v/ u minuskuli piše $u$, a $V$ u majuskuli, i u Juditi i u svim uspoređenim rukopisima. U svim se uzorcima za /v/ ponekad piše redundantno ili zamjensko $f$, najčešće u kosim padežima s dočetkom -ouf, -of, ali i drugdje kada valja naglasiti da se čita /v/, a ne /u/. Marulićev je slovopisni hapax pisanje dvostrukoga uu za /v/. Maretić (1889: 365) izrijekom tvrdi da se u čitavoj hrvatskoj latiničnoj slovopisnoj povijesti do reforme u 19. st. udvostručeno $u$ u za /v/ nalazi samo »u jednoga pisca (Marulić), koji ima i druge znakove $[\mathrm{u}, \mathrm{f}]$ «. Maretić je u pravu, tako je pisao i tiskao Marulić u Juditi, ali i svi njegovi pisari iz gornje tablice, čime je na jedinstven način potvrđena slovopisna međuovisnost uspoređenih rukopisâ iz Splita nastalih za njegova života, bez obzira na to tko ih je pisao, Marko ili njegovi pisari.

Već spominjana štokavska metateza $v s$ - $>s v$ - provedena je u Juditi skoro dosljedno, isto tako, uz pokoju iznimku, u najstarijem dijelu Vartala i u Zardinu (1508), tj. u oba rukopisa za koje držimo da su i Marulovi pisoruci. U Firentinskom zborniku i u drugim ovdje uspoređenim rukopisima dolazi i jedan i drugi oblik ili prevladava $v s$ - $/ f_{\mathcal{f}}$. U rukopisu No $6 \mathrm{iz} 1514$. skoro isključivo stoji $f_{\mathcal{S}}$-. To samo potvrđuje da je Marulić u ortografiji kao i u morfologiji, zbog relativno česte štokavske fleksije, bio ispred svojih pisara i splitskih uzanci, gdje metateza $v s-/ f s_{-}->s v-u$ to doba još nije bila dosljedno provedena. A bilo bi i pravo čudo da je ta štokavska metateza već početkom 16. st. postala dominantna u čakavskom Splitu. Marulić je, s druge strane, komunicirao s brojnim ljudima i izvan Splita, pa je tako prijateljevao s dominikancem i propovjednikom Dominikom Bućom, ${ }^{51}$ štokavcem iz Kotora, odatle i njegovo poznavanje i svjestan izbor što-

51 Dominik Buća, (Dominicus, Domenico Buchia, Bucchia), Kotor o. 1480. - Kotor o. 1560. Prema Stjepanu Krasiću 1497. stupio je u Dominikanski red u Dubrovniku, a 1499. nastavio u Napulju započeti studij filozofije. Opća skupština Dominikanskog reda odobrila je 1515. njegov i Pribo- 
kavskih oblika (volgare illustre). Provedena metateza u dva kodeksa kao i u tiskanoj Juditi samo dodatno potvrđuje da je rukopise Vartal (umetak) i Zardin i pisao i prepisao sam Marulić, pa ih nisu, kao inače često, prepisali njegovi pisari.

Pregleda radi želim još tabelarno pokazati koji posao čeka one marljive radnike koji budu prionuli izdavanju Marulovih hrvatskih djela u okviru projekta Hrvatska proza Marka Marulića. U njemu se pripremaju kritička izdanja hrvatskih mu djela diplomatičkom transliteracijom i fonematičkom transkripcijom usporedno, ${ }^{52}$ tj. drama, vitâ, propovijedi, prijevodâ, parafraza, prepjeva i sl., dodaju se latinski i talijanski predlošci kao i transverzalne konkordancije rječnikâ. To omogućuje uvid u način njegova rada, prevođenja, u terminologiju, hapax legomena i sl., što metodološki treba omogućiti ne samo verifikaciju nego i eventualnu falsifikaciju predmnijevane atribucije. Zbirka najstarijih hrvatskih pučkojezičnih proznih rukopisa, iako tu ima dosta i poezije, autora Marka Marulića, obuhvaća jednu cijelu priručnu biblioteku, uglavnom neobjavljenih, donedavno i neatribuiranih rukopisa (Pandžić 2009). U središtu su kritike teksta i izdavačkog projekta sljedeći rukopisi, njegovi su u cijelosti ili dijelom:

a) Stara splitska zbirka Marulićeve sestre Bire prenesena u Zadar, rasprodana u Londonu 1825.:

No1 (Ashb. 1582, tj. Firentinski zbornik). - Firenca

No3 (HS 5, Cvitje), nedatiran, ali po filigranima $(1507,1519)$ negdje oko 1520. (usp. Hamm 1987: 37). - Beč

No3 (HS 6, Od rasutja jerosolimskoga) iz 1513. - Beč

No6 (Add. 10394, Upute za dobar život redovnicama) iz 1514. - London

No9 (HS 4, Dijalozi Grgura Velikoga) iz 1513. - Beč

No11 (Add. 10625), Govorenja suerhu vecere, također 1513. - London

No12 (R 4903). - Zagreb (NSK). ${ }^{53}$

jevićev naslov doktora teologije. Marko Marulić upravo je na njegov nagovor napisao poznatu protutursku poslanicu papi Hadrijanu VI., posvetivši ju samom Bući (Epistola [...] ad Adrianum $V I$, Romae 1522). Marulić tu piše da je rado nazočio njegovim propovijedima.

52 Međunarodni je projekt osmišljen s nakanom da se u jubilarnoj godini 2024., uz 500. obljetnicu smrti Marulove, i njegovo hrvatsko djelo prikaže u donekle cjelovitijem izdanju. Sve će naravno zavisiti od broja, umijeća i opterećenosti angažiranih suradnika.

53 >Londonski< kao i ‘zadarski< rukopis prijevoda Naslidovanja (R-134 iz Gradske knjižnice u Zagrebu, odatle otuđen), već su objavljeni, pa nisu izravni predmet izdavanja, nego stalno pomagalo za identifikaciju i usporedbu Marulićeva leksika i sintakse. Slično je is R 3171, tj. poslanicama Marulovim Katarini Obirtić. 
No 13 (R 6633 iz 1508.), Zardin od molitve. - Zagreb (NSK)

No 14 (R 3662). - Zagreb (NSK)

No 16 (Add. 10395)..$^{54}$ - London

No 21 (R 6634). - Zagreb (NSK)

b) rukopisi splitskoga podrijetla, većinom iz legata Ivana Kukuljevića, danas čuvani u Zagrebu i Dubrovniku

1. IV a 31 (f. $220^{\mathrm{r}}-265^{\mathrm{r}}$ ), tj. najstariji od svih rukopisa ovdje (oko 1500.), umetnut u Vartal Petra Lucića, koji je opet najvećim dijelom također Marulićev. - Zagreb, Arhiv HAZU

2. I a 5, Oficij Blažene Dive Marije. - Zagreb, Arhiv HAZU

3. I b 55, Nauci [...] sv. Bernarda sestri svojoj, Govorenje sv. Bernarda od duše osujene i dr. - Zagreb, Arhiv HAZU

4. IV a 34, Nauci [...] sv. Bernarda sestri svojoj. - Zagreb, Arhiv HAZU

5. I b 83 (ff. $325^{v}-330^{v}$ ), ulomak iz Lulićeva zbornika, ali i drugi dijelovi istoga. - Zagreb, Arhiv HAZU

6. I b 127. Život sv. Jerolima (usp. Jagić 1869), ${ }^{55}$ slična inačica je u Fireninskom zborniku. Obje bi trebale biti kritički priređene i objavljene usporedno s Marulićevim latinskim tekstom Vita divi Hieronymi. - Zagreb, Arhiv HAZU

7. I a $44\left(\right.$ ff. $\left.1^{\mathrm{r}}-31^{\mathrm{r}}\right)$. Muka sv. Margarite, Život sv. Marte. - Zagreb, Arhiv HAZU

8. $\mathrm{XV}-44 / 8$ - Zagreb, Arhiv HAZU

9. R 589 (str. 323-368). Uz neke pjesme Marka Marulića, dijela njegove drame Govorenje sfetoga Bernarda od duše osujene, tu su i tri hrvatske vitae splitskih prvomučenika Dujma, Staša i prijenosa njihovih tjelesa u Split grad. Latinske inačice, najvjerojatnije također Marulićeve, istih vitâ donosi Farlati (1751). Sve tri se izdaju, hrvatski i latinski. - Knjižnica Male Braće u Dubrovniku.

$54 \quad$ Taj se Život sv. Marte ne podudara s kraćim Životom sv. Marte iz I a 44, ff. $28^{\mathrm{r}}-31^{\mathrm{r}}$. Nisam još tražio latinske predloške, tek nakon što ih se nađe, moći će se, po načinu prevođenja i izabranom leksiku, više reći o prevoditelju i(li) piscu. Već spomenuti epigram s početka Života u I a 44, f. 28, ipak je Marulićev.

55 Jagić (1869) je u istom radu objavio i Život sv. Katarine, podrijetlom iz samostana sv. Marije u Zadru. Valjat će ga usporediti s drugim rukopisima ovdje. 


\section{Ekskurs o književnosti, teologiji i ideologiji}

Smjena stoljećâ quattrocento - cinquecento bila je, izgleda, i vrijeme višestrukog osobnog i stvaralačkog izazova u životu Marka Marulića (1450. - 1524.). Hodočastio je u Rim povodom svete godine 1500. Tom je zgodom vjerojatno pohodio i druge talijanske gradove, nabavljao i studirao knjige, zapisivao antičke natpise, pratio književne, teološke i ikonologijske raspre tada već izdiferenciranim humanističkim refleksijama o subjektivnosti čovjeka, odnosno o njegovu stvaralačkom, poetskom, teološkom i inom geniju.

Filozofska i teološka, poetska i poetološka, antička i suvremna djela naglo su se proširila u Italiji od sredine 15. st. zahvaljujući novoj, tipografskoj tehnologiji, učenim grčkim izbjeglicama i antičkim kodeksima koje su donijeli, a sve se tiskalo uglavnom u izvornim jezicima, i na latinskom i grčkom, te na volgare. Očito je Marulić tada u Italiji i zbog plurilingvalne potke renesansne kulture dobio dodatnu motivaciju da svoj književni talent isproba i u najzahtjevnijem, epskom pjesničkom stilu i to na materinskom pučkom jeziku, po uzoru na onaj u kojemu je bila pisana i već višekrat tiskana Božanstvena komedija, odnosno, po poznatoj Danteovoj maksimi iz De vulgari eloquentia, na stilistički dotjeranom volgare illustre.

Judita u svakom slučaju predstavlja, svjestan je toga i sam Marulić, ’kvantni skokı u hrvatskoj književnosti i jeziku. Ta je književnost sada oplemenjena epskim umjetničkim autorskim pjesništvom, dočim je Marulov dvostruko rimovani dvanaesterac usporediv i s Vergilijevim daktilskim heksametrom i Danteovim jedanaestercem u tercinama, pa Judita i po tome staje uz bok, ili barem u prvi red iza djelâ Dantea, Vergilija i Homera, a hrvatska književnost i jezik postaju u punom smislu renesansni. S latinskim epom Davidias pak, samo nekoliko godina kasnije, i u žanrovskom i jezičnoformalnom smislu, hrvatska je renesansna književnost postigla i onu očekivanu širinu, koja se tražila u to doba da bismo ju danas uopće mogli nazvati renesansnom. I zbog toga je hrvatska književnost, zahvaljujući prije svih Maruliću, jedina renesansna u slavenskome svijetu u doslovnom smislu te riječi, jer obnavlja i oponaša i antičku poeziju na području staroga Rimskog Carstva, a i vrlo rano sudjeluje u ranonovjekovnoj pluralizaciji pjesničkih tema i motiva, što je inicirao Petrarca.

Jezik prvog hrvatskog epa nije staročakavski ili starohrvatski, kako to neki današnji jezikoslovci iz svoga metodološki preuskog (Engführung) akcentuacij- 
skog i(li) fonologijskog monokularnog izvidišta s anakronističkim pojmovljem simplifliciraju, nego izrijekom hrvatski narodni jezik, koji tvorac umjetničkog djela oplemenjuje (volgare illustre). Taj se jezik, od inicijalnog i ujedno višestrukog Marulićeva zahvata, pa sve do danas, postojano razvija kao književni, bez obzira na razne govorne inačice i dijalektne izoglose, opet slično načinu i smjeru dugog puta normiranja koje su talijanskom jeziku svojim djelima trasirale `tri krune toskanske`, Dante, Petrarca i Boccaccio.

Epski uzor i model pročišćenog i stiliziranog narodnog hrvatskog jezika došao je od Danteova ideala, isto tako naravno i alegorijska, >okomita perspektiva epa. Da mu je Dante bio smjerodavan javlja i svom prijatelju Jeronimu Ćipiku već u srpnju 1501. i smiono zaključuje kako sada "jezik slovinski ima svoga Dantea/ la lengua schiava ha el suo Dante«. Međutim, u tzv. produktivno-estetskoj osnovi, dakle u smislu inspiracije i motivacije, na pisanje poezije potakao ga je i Francesco Petrarca. Možda upravo s jednim Petrarcinim literarnim toposom Marulić i započinje posvetu Judite prijatelju don Dujmu Balistriliću, prvopojcu splitskomu i kumu svomu.

Petrarcu Marulić i inače često pokušava oponašati u Juditi, Suzani i Davidijadi, navlastito pri ‘horizontalnim`, piktoralnim opisima svoga rodnog grada, splitskih i šoltanskih krajobraza, vojničkih i ženskih odijela, što je zapravo nasljedovanje Petrarcine početne ranonovovjekovne pluralizacije poetskih motiva i estetskih kriterija. Posveta Judite reflektira, međutim, i znameniti uspon na Mont Ventoux ${ }^{56}$ (Ad familiares IV, 1) od 26. travnja 1336., dakle na Veliki petak, ${ }^{57}$ kada se Petrarci užegla misao (Ad posteros, 26) da u herojskom metru napiše svoj latinski ep Africa o Drugom punskom ratu (sexta quadam feria maioris hebdomade, cogitatio incidit, [...] ut [...] poeticum aliquid heroico carmine scriberem). Nešto slično zgodilo se i Maruliću. Vrativši se u Split s već spomenutog napornog hodočašća u Rim 1500., uskoro se, tj. »sih dan svetih korizmenih« čitajući starozavjetnu »historiju one počtene i svete udovice Judite«, užeže

56 Taj se događaj i navedeno pismo smatraju početkom poetske pluralizacije u talijanskom i uopće europskom pjesništvu, jer je Petrarca u poeziju uveo i motive krajobraza, prirode općenito i poetsku emocionalizaciju doživljaja prirode. Bio je i inače, kako to veli Stierle (2003: 9), »Genie der Anfänge«. O njegovoj višestruko inovativnoj ulozi pri izgradnji prvih temelja ranonovovjekovne filozofije, poezije i kulture općenito usp. epohalno djelo Thomasa Leinkaufa (2017: 251-313 et passim); o hermeneutici u renesansi dobre opažaje ima Blum (2010). U romantizmu apsolutizirana `laurizacija< Petrarcina pjesništva s vremenom je odvukla pogled s brojnih inih aspekata njegova djela.

$57 \quad$ I njegov susret s Laurom 6. travnja 1327. dogodio se, kako bilježi, na Veliki petak. 
u njemu odlučujuća pomisao: »ulize mi u pamet da ju stumačim našim jazikom, neka ju budu razumiti i oni ki nisu naučni knjige latinske i djačke«. Svoj je epos zgotovio ubrzo, nekoliko dana po Uskrsu, »u godišće parvo nakon tisuća i pet sat, na dvadeset i dva dni miseca aprila«.

Međutim, valja pretpostaviti da Marulić svoj carmen heroicum nije sastavio namah tijekom jedne korizme, kako to tvrdi slijedeći Petrarcin topos; nije ni Petrarca sastavio svoje pismo, iako tako piše, neposredno nakon silaska s Mont Ventouxa istog Velikog petka navečer VI. Kalendas Maias 1336, nego je i Petrarcu i Marulića kontemplativni i stvaralački naboj vjerojatno prožimao dulje vrijeme. Juditu zaključuje stihovima: trudna toga plova ovdi jidra kala/ plavca moja nova [...], što svjedoči da mu pero nije odveć lako lepršalo, dočim brojni citati u Petrarcinu pismu upućuju na pomisao da mu je pri ruci morala biti prava mala priručna biblioteka rukopisâ kada ga je sastavljao, što se u skromnom seljačkom svratištu ispod Mont Ventouxa tog Velikog petka ipak nije moglo zateći.

Prvi hrvatski umjetnički epos narodnoga jezika je - metaforički rečeno Marulova plavca nova (brodica, barka nova), zgotovljena (spustila je jedra) tek nakon »trudna plova«. Moguće da je tu mislio i na poteškoće kako iznaći hrvatski herojski metar za svoje djelo, što je u njegovu slučaju bio dvostruko rimovani dvanaesterac uz opkoračenje (dva dvostiha po četiri polustiha), ali je bez sumnje time htio naglasiti i to da Judita nije bila i njegova "plavca prva«. Stvarao je i ranije, a mnogo više kasnije, ne samo latinska, po cijeloj Europi tiskana, prevođena i čitana djela, nego i brojne hrvatske pjesme u osmercu i dvanaestercu, hrvatske drame (prikazanja), prijevode i prozne sastavke, što, međutim, većim dijelom stoljećima ostade u rukopisu, do danas skrito od očiju javnosti.

Pored svojih velikih pjesničkih uzora Dantea i Petrarce, obojicu prevodi, Dantea na latinski, a Petrarcu na hrvatski i latinski, rado slijedi Vergilija, koji mu je nepresušna inspiracija za heksametare Davidijade. Ipak, na prvom mjestu svih Marulićevih pjesničkih i teoloških nastojanja, poglavito kod traženja motivacijskih uzora, slika, figura i primjera za primarni cilj, kršćanski ponizno življenje (humiljenost, uljudnost) nasuprot oholosti, stajala je Biblija. I za mane i za kreposti ona daje primjere, naravno i za posljedice takva življenja. Starozavjetne su mu ličnosti služile kao alegorijske prefiguracije novozavjetnih, ali i kao exempla kreposnog življenja za adresate. Magnificat iz Lukina evanđelja dao mu je priliku da se ujedno okuša i u poeziji i u egzegezi izlaganjem biblijskog teksta hrvatskim jezikom redak po redak, i to prema vlastitom prelijepom 
prijevodu, tražeći pritom ne samo literalni nego, i zbog svoje "poljubljene sestrice«, i duhovni smisao hvalospjeva. I prepjev i egzegezu Magnificata Marulić brižljivo izrađuje, naravno i zato jer je za njega Marija prauzor poniznosti i vrelo neposredne, nepatvorene vjere i ufanja u Gospodina. Magnificat je preko Marije središnji duhovni - ali i poetski - izričaj doživljene vjere i >oćućenjaく Uzvišenoga u poniznosti. Jedinstvenim prepjevom i nadahnutim izlaganjem htio je taj Marijin ushit približiti i svojoj sestri na onom jeziku koji je ona najbolje ćutjela i razumjela. Slična mu je nakana bila i s drugim djelima koja je pisao za svoju sestru.

Marulićeva poznata latinska i dobrim dijelom nepoznata hrvatska djela i prijevodi napisani su i u duhu u ono doba ‘autsajderske`, nove pobožnosti (devotio moderna). Upravo zbog toga neka od njih postaju europski `bestselleri<, gdje se i poezija i teologija i duhovna drama uzimaju kao sredstvo postignuća osjećajne involviranosti, duhovne i intelektualne poticajnosti, ponajprije kod onih manje učenih. Stoga mu je i poezija i proza, drama i epika, na transverzalan i univerzalan način nastojala integrirati razne motive i primjere (exempla) koje je nalazila u izvrsnom pjesništvu klasične starine, Dantea i Petrarce, te, uvijek iznova, Biblije, nepresušnom vrelu njegovih poetskih slika i uzoritih primjera ponizna življenja. ${ }^{58}$ Svetačke vitae, počev s Ivanom Krstiteljem i Jeronimom, njih dvojicu je uvijek opisivao usporedno, bili su daljnji primjeri, sveta prikazanja opet uprizorenja najljepših od tih primjera, a spisi otaca dobrodošle interpretacijske pomoći kod tumačenja i Biblije i kršćanske nauke općenito. I lijepa poezija i prozna Biblija vodile su osjećajnog suvremenika do duhovne uzvišenosti, pa u hvalospjevu kao što je Magnificat, slično je i s ambrozijanskim Te Deum lauda$m u s$, i Biblija i poezija postaju inicijalni duhovni kvasac za jedinstven individualni doživljaj onoga što nazivamo Uzvišenim. Zbog toga Marulić i nastoji sva svoja prozna djela providjeti i stihovima koji potiču na lektiru i ১oćućenjeく, i to za svakog adresata po mjeri njegove izobrazbe, odnosno sposobnosti >oćućenjaく. Svojoj >sestrici< i njezinim sestrama čini to na hrvatskome, biblijski hvalospjev prevodi u zahtjevni dvanaesterac, što je ujedno i profinjeno tumačenje istih latinskih stihova, najprije hrvatskim stihovima a potom i objasnidbeno. $U$ istom firentinskom tekstu Života sv. Ivana Krstitelja u kojemu se nalazi i Magnificat, u

58 Marulić u svojoj alegorizaciji ne može koristiti exempla poput Herkula, ne zbog toga što Herkul i njegova djela ne bi mogle biti vrsne prefiguracije, nego ponajprije stoga što su Herkulovi čini mogli biti prefiguracije samo za apoteozu moćnih vladara, dočim Marulić, prema biblijskim uzorima (Marija, David, Suzana, Judita, Estera itd.), želi uzvisiti malene i ponizne. Utjecaje patrističke egzegeze na Marulićevu Davidijadu, ali ne samo na taj epos, temeljito je istražio Palameta (2017). 
dvanaesterce pretače i Petrarcin sonet Io vo piangendo (f. $15^{\mathrm{rv}}$ ). Predajući u tisak latinski Evangelistarium pridodaje na koncu i svoj vrlo zahtjevni latinski prepjev završne pjesme iz Canzoniera Francesca Petrarce Vergine bella, odnosno Ad virginem beatam. Kada je pak za tisak zgotovio svoj latinski ep Davidias pridodao mu je, što je bez sumnje moglo dodatno ushititi i najzahtjevnije ljubitelje i klasične i Danteove poezije, prvo pjevanje Danteova Pakla iz Božanstvene komedije u svom latinskom heksametru.

Veliki nesporazum nastade, traje do danas, kada se Marulićevu poeziju i njegov hrvatski jezik uznastojalo ideološki odijeliti od njegove - krivo razumljene - idejne, >moralističke` poruke. U tom je smislu veliki hrvatski književnik Miroslav Krleža povodom 500. obljetnice Marulova rođenja (1450. - 1950.), cenzurirao i dijelomice uništio ${ }^{59}$ već tiskani Zbornik u proslavu petstogodišnjice rođenja Marka Marulića 1450-1950, optuživši Marulića za reakciju i protureformaciju, jer da on dolazi iz društva kardinala Bellarmina (Balić 2016, Pšihistal 2018: 361- 363). Krleža nije znao da je tiskar Adam Petri u Bazelu s frontispicom Marulićeve Institucije (1513) tiskao (Posset 2018: 167) i Lutherovu Propovijed o najsvetijem sakramentu (1519) te da su se Markova djela podjednako dobro čitala i u katoličkim i u protestantskim dijelovima Njemačke tijekom skoro dva stoljeća. Ovo stoga što je njegova teologija, slijedeći i sv. Bernarda kao i Luther, uvijek polazila od svagdanjih primjera, biblijskih i svetačkih zgoda, kao i od ’horizontalnih opažaja običnog čovjeka, a nikad od apstraktnih definicija koje su bile razvijene u skolastičnoj teologiji prema peripatetičkoj filozofiji. Upravo je to tražila i reformacija. Usput, kardinal Roberto Bellarmin (1542. - 1621.) rodio se 18 godina nakon Marulove smrti, pa je Krleža, moguće, o učenom kardinalu nešto saznao iz drame Bertolda Brechta Leben des Galilei. Potom je Marulića jednostavno ubacio u svoju ideološku šablonu ispravne povijesti i krive književnosti. Možda mu je iskustvo s pjesnikom Marulićem, koji nije ni tražio ni dirao tuđe sfere slave `za volju oholosti<, baš u to vrijeme pomoglo da pripremi svoj, nekoć vrlo hvaljeni, >Ljubljanski referatく o slobodi književnosti.

Taj novostvoreni, do dana današenjega vegetirajući, negativni naboj prema Maruliću, doveo je i do pokušaja `spašavanja lika mu i djela, pa su brojna njegova kao pobožna detektirana djela, pripisivana srednjovjekovnoj anonimnoj, nipošto autorskoj renesansnoj književnosti. Takva argumentacija svjedoči o nepoznavanju prije svega renesanse kao kulturne epohe uopće, opusa Marka 
Marulića i posebno. Uspjela je ipak spriječiti, iskustvo iz 1950. bilo je još svježe, službeno obilježavanje 450. obljetnice pjesnikove smrti (1974), samim time i novi zamah $\mathrm{u}$ istraživanju pjesnikovih proznih djela. Knjiga Carla Verdianija O Marulićevu autorstvu Firentinskoga hrvatskog zbornika (1973), u to doba iz primarno ideoloških razloga osporavana, zbog svoje dosljedne znanstvene metode na koncu je ipak pomogla da danas otkrivamo i(li) iznova prepoznajemo i brojna hrvatska djela Marulova, koja su već više puta bila otpisana kao srednjovjekovna, moralistička i nazadna, a onomad i kao »dubiozna«.

Jedan je drugi veliki hrvatski književnik povodom 500. obljetnice Judite (2001) i Frankfurtskog sajma knjiga, okrugle obljetnice i prisjećanje na djelo začetnika moderne hrvatske književnosti očito su bile veliki izazov za neke suvremenike, Marka Marulića u Frankfurter Allgemeine Zeitungu usporedio s mongolskim osvajačem Džingis-kanom. Razlog je i ovaj put, kao i 1950., bio vjerojatno isti, Marulića se smatralo - ništa netočnije od toga - netolerantnim kršćanskim zelotom, jer se, nakon pogibije hrvatskog bana i prijatelja mu Petra Berislavića (20. svibnja 1520.), obratio za pomoć papi. Skitio je Marko i Molitvu suprotiva Turkom i razne poslanice u vrijeme kada su Turci bili na puškomet od Splita, a bitke se vodile za obranu Klisa. To mu je, uz ideološki >dubioznu poeziju, možda bio glavni grijeh i uzrok višekratnog pokušaja izopćenja, slijedom svojevrsne nepisane fetve (ar.فتوى), i iz korpusa te - i navlastito - iz kanona hrvatske književnosti. ${ }^{60}$

Nakon Marulove smrti (1524), skore epidemije kuge u Splitu i pada Klisa (1537), na dulje vrijeme umukoše muze u Splitu. U zaborav utonuše i brojna književna djela napisana i oslikana rukom najpoznatijeg splitskog i hrvatskog začinjavca, oca hrvatske književnosti, jezika i novovjekovne pisane kulture u punoj širini te riječi.

\section{Sažetak}

$\mathrm{Na}$ koncu ove istraživačke studije s Magnificatom u prijevodu i s egzegezom Marka Marulića u središtu zanimanja, izdvajam samo neke rezultate:

60 Da se lektira Marulićevih djela trenutačno izbacuje iz nastavnih planova za hrvatske škole svakako je barem dijelom i odraz odioznosti prema njegovoj osobi i djelu koja je ideološki uvijek iznova forsirana u posljednjih 70 godina. Ipak, daleko opasnije za hrvatsku književnu republiku jest činjenica da se Marulićeva književna djela svjesno nastoji zanijekati na fakultetima i znanstvenim institutima. Sustavno se sputava istraživanje njegovih izgubljenih djela i onemogućuju rasprave o njegovu realnom udjelu u izgradnji početaka hrvatske novovjekovne književnosti. 
1. Marulić je po vlastiom svjedočanstvu i prema dva epigrama Bartolomeja Merule barem od 80-ih godina quattrocenta pisao pobožna književna djela (Castalidum cultor). Imao je i pisare koji su mu pomagali prepisivati njegove rukopise ili zapisivati diktate. To je vrlo važan podatak, kako se razlika u pisoruku i slovopisu ne bi uzimala kao dokaz da autor nekog rukopisa ne može biti Marulić. Merulin epigram Ad scribas domini Marci je dragocijeno svjedočanstvo o tome, Marulićeva potvrda iz 1507. također.

2. Uspoređujući sedam prijepisa njegova prijevoda Magnificata utvrđeno je da su dva najstarija interkalirani u Život sv. Ivana Krstitelja u Vartalu i u Firentinskom zborniku. Njihova je međuovisnost neupitna, ali je firentinskoj inačici pridodana i egzegeza (izlaganje) hvalospjeva koje nema u Vartalu. Ona slijedi ne samo tekst Lk 1, 46-55 nego ponegdje doslovce na hrvatski prevodi i rečenice iz komentara Nikole de Lyra. Tu latinsku Bibliju s komentarima Nikole de Lyra u četiri sveska (1489) posjedovao je Marulić do svoje smrti i na njoj bilježio rubne glose i crteže. Nijedan pojedinac u Splitu, iz Splita dolazi tekst Firentinskoga zbornika, nije imao to izdanje Biblije, niti je tako intenzivno studirao Bibliju u ono doba kao Marulić, nitko drugi kod Hrvata nije zapisivao rubne bilješke i crteže na Bibliji s Lyrinim komentarima. Stoga je uz brojne druge dokaze koje je iznio Verdiani jedini mogući zaključak: Marulić je autor ne samo prijevoda i egzegeze Magnificata nego i cijeloga zbornika do f. 120, gdje se nalaze brojni drugi citati i stihovi iz iste Biblije i iz njegovih inih djela.

3. Egzegeza Magnificata iz Firentinskog zbornika donosi nekoliko negativnih biblijskih primjera i grijeha počinjenih »za volju oholosti«. Iste te nalazimo u skoro svim latinskim djelima Marulovim, ali i u rukopisu Pocatach od fsache criposti, milosti i dusefnoga utiscenia (R 3662; No 14), koji ovdje prvi put pripisujem Marku Maruliću.

4. Marulićev prijevod Magnificata nalazimo uz ine himne u njegovu proznom prijevodu i u Oficiju blažene dive Marije (I a 55). Bilo je pokušaja da mu se ospori autorstvo. Po jednoj iznimno rijetkoj jezikoslovnoj osobini u hrvatskome jeziku prepoznajemo Marulićevo autorstvo i u inim dijelovima, a ne samo u himnima toga oficija. Riječ je o kategoriji produševljenosti i u množini, kojom se Marulić često koristi u svojoj stilistici, pa se ne može tvrditi da bi netko drugi mogao taj oficij prepisivati iz 
dubrovačkih ili glagoljskih oficija, koji tu kategoriju ne poznaju. Dakle, i Oficij blažene dive Marije (I a 55) je djelo Marulovo i kao takvo treba biti izdano.

5. Tri druga dijela Firentinskoga zbornika imaju svoj predložak u splitskom kodeksu Zardin od molitve ( $\mathrm{R} 6633$, No 13); Marulićevi su i prijevod i pisoruk. Isti Zardin ima neke prevedene dijelove kao i Dijalozi Grgura velikoga (No 9), također i vrlo sličan leksik. Ti Dijalozi su opet u brojnim pojedinostima povezani s nekoliko drugih rukopisa iz iste izvorne zbirke (No1 - No 21) koju je čitala Marulićeva sestra Bira. Zajedničko im je podrijetlo neupitno, Marulovo.

6. Pokušaji da se ospori Marulićevo autorstvo i Firentinskog zbornika i drugih kodeksa jedinstvene i prve zbirke hrvatske pučkojezične proze uopće, počivaju na povijesnolingvistički anakronim metodološkim zasadama, na rabulistici umjesto logici, što se pokazuje u poglavlju 6. Koji je slovopis korišten u Splitu u rukopisima koji su nastali za Marulova života pokazuje sinopsa u poglavlju 7.

7. U 8. poglavlju ukratko se govori o odnosu književnosti i teologije kod Marulića i o ideološkim nasrtajima na njegovu književnost u zadnjih sedam desetljeća. Nju je trebalo potisnuti barem iz kanona, kada se već ne može iz korpusa, hrvatske književnosti. U toj se paradigmi perpetuiranom rabulističkom, anakronističkom i samoreferencijalno zatvorenom metodom svaki novopronađeni Marulićev hrvatski rukopis do danas smjesta proglašava >dubioznim<.

8. Na koncu su popisani Marulićevi rukopisi iz Kukuljevićeva legata, iz Dubrovnika i iz zbirke Marulićeve sestre Bire, koji su predmet međunarodnog znanstvenog izdavačkog projekta Hrvatska proza Marka Maruli$c ́ a$. Na taj se način mala, ali izabrana grupa istraživača Marulićeva djela želi pripremiti za obilježavanje 500. obljetnice smrti utemeljitelja ranonovovjekovne hrvatske književnosti na novohrvatskome jeziku (volgare illustre). 


\section{Bibliografija}

\section{Rukopisi}

Arheološki muzej, Split, Arhiv Julija Bajamontija, pozicija III, 5c - 1-5.

Arhiv HAZU, Zagreb

I a 5, I a 44, I b 55, I b 83, I b 127, IV a 31, IV a 34, XV-44/8

Bibliteca Nazionale Centrale, Firenze

Magliab. VII, 1183, ff. $122^{\mathrm{v}}-136^{\mathrm{v}}$

Biblioteca nazionale Mediceo-Laurenziana, Firenze

Aschb. 1582

British Library, London

Add. 10394, Add. 10395, Add. 10625

Knjižnica i Arhiv Male braće, Dubrovnik

R 589

Nacionalna i sveučilišna knjižnica, Zagreb

R 3171, R 3662, R 4083, R 6633, R 6634

Universität Wien, Fachbereichsbibliothek Slawistik

MS 4, MS 5, MS 6

\section{Literatura}

Badalić, Josip. 1952. Inkunabule u NR Hrvatskoj. Zagreb: JAZU.

Badalić, Josip. 1957. »Marulićevi hrvatski autografi u Arhivu Jugoslavenske akademije«. Filologija, 1.37-61.

Balić, Davor. 2016. »Krležini iskazi o Maruliću i njegovu opusu«. Prilozi za istraživanje hrvatske filozofske baštine, 42. 353-419.

Berić, Dušan. 1950. »Bibliografske bilješke Julija Bajamontija o djelima Marka Marulića«. Vjesnik bibliotekara Hrvatske, 1/4. 289-293.

Bernardus, Claraevallensis. 1849. Liber de modo bene vivendi, ad sororem. PL 184, 1199A 1305B.

Blum, Paul Richard. 2010. Philosophy of religion in the Renaissance. Farnham: Ashgate.

Božićević, Frane. 2007. Život Marka Marulića Splićanina. Priredio i preveo Bratislav Lučin. Split: Književni krug.

Bratulić, Josip. 1998. »Poslanice Marka Marulića Katarini Obirtić«. Colloquia Maruliana, 7. 27-35.

Bratulić, Josip. 2014. »Trogirski (Jagićev) Život svetog Jeronima«. Zadarska smotra, 58. $27-42$.

Duplančić, Arsen. 1996. „Ostavština Julija Bajamontija u Arheološkom muzeju u Splitu i prilozi za njegov životopis." U: Splitski polihistor Julije Bajamonti. Zbornik radova 
sa znanstvenog skupa održanog 30. listopada 1994. godine u Splitu. Split: Književni krug.

Eze, Anne-Marie. 2016. »Abbé Luigi Celotti and the Sistine Chapel manuscripts«. Rivista di storia della miniatura, 20. 139-154

Fancev, Franjo. 1925. »Prilozi za povijest hrvatske crkvene drame«. Nastavni vjesnik, 33. 109-124.

Fancev, Franjo. 1932. »Hrvatska crkvena prikazanja«. Narodna starina, 11. 143-168.

Fancev, Franjo. 1932a. »Građa za povijest hrvatske crkvene drame«. Građa za povijest književnosti hrvatske, 11. 11-38.

Fancev, Franjo. 1933. Nova poezija Splićanina Marka Marulića. Rad JAZU 245. Zagreb: JAZU.

Fancev, Franjo, prir. 1934. Vatikanski hrvatski molitvenik i Dubrovački psaltir. Zagreb: JAZU.

Fancev, Franjo. 1938. „Dvije poslanice Marka Pecinića (Marulića) benediktinki Katarini Obirtića«. Građa za povijest književnosti hrvatske, 13. 187-192.

Farlati, Daniele, ed. 1751. Illyricum sacrum. Tomus primus. Venetiis: Sebastianus Coleti.

Filipović, Vladimir. 1983. »Osnovi etičko-filozofske orijentacije Marka Marulića«. Prilozi za istraživanje hrvatske filozofske baštine, 9. 3-22.

Fisković, Cvito. 1986. »O Marulićevu slikanju«. Prilozi povijesti umjetnosti u Dalmaciji, 26. Split: Regionalni zavod za zaštitu spomenika kulture. 393-424.

Glavičić, Branimir. 1993. „O nekim problemima Marulićevih latinskih tekstova«. Colloquia Maruliana, 2. 13-15.

Hamm, Josip, prir. 1978. Dijalozi Grgura Velikoga u prijevodu iz godine 1513. Zagreb: JAZU. Hamm, Josip, prir. 1987. Acta Pilati i Cvitje. Zagreb: JAZU.

Jagić, Vatroslav. 1869. »Ogledi stare hrvatske proze«. Starine, 1. 216-236.

Jurić, Šime. 1991-1997. Katalog rukopisa Nacionalne i sveučilišne biblioteke, sv. I-V. Zagreb: NSK.

Kapetanović, Amir. 2010a. »Dva sveščića stihova iz XVI. stoljeća, navodno Mihovila Vrančića Šibenčanina». Čakavska rič, 38. 183-207.

Kapetanović, Amir i dr. prir. 2010b. Hrvatsko srednjovjekovno pjesnišstvo. Zagreb: IHJJ.

Kapetanović, Amir. 2011. »Versificirana biblijska pripovijest o Esteri (XVI. st.) u kontekstu hrvatske srednjovjekovne književne baštine i Marulićeva pjesničkoga kruga«. Colloquia Maruliana, 20. 5-30.

Kukuljević-Sakcinski, Ivan. 1869. »Marko Marulić i njegovo doba«. Stari pisci hrvatski, sv. I. I-LXXVII. Zagreb: JAZU.

Kulundžić, Zvonimir. 1976. »Pronalazak izgubljenog djela Marka Marulića na hrvatskom jeziku starijeg od Judite«. Republika, 6. 681-700.

Kulundžić, Zvonimir. 1977. Ta rič hrvacka. I. Zagreb: vlastita naklada.

Leinkauf, Thomas. 2017. Grundriss. Philosophie des Humanismus und der Renaissance (1350-1600). Zwei Bände. Hamburg: Felix Meiner. 
Lohse, Rolf. 2015. Renessancedrama und humanistische Poetik in Italien. Paderborn: Wilhelm Fink.

Lucić, Petar. 1990. Vartal. Prir. Nikica Kolumbić. Split: Splitski književni krug.

Lučin Bratislav. 2010. »Splitska pjesmarica trogirskoga kaptola: opis, sadržaj, auktori, predlošci«. Colloquia Maruliana, 19. 55-93.

Lučin Bratislav. 2017. »Prema kritičkom izdanju Marulićevih stihova: Judita kao orijentir«. Colloquia Maruliana, 26. 5-73.

Malić, Dragica. 1976. »O Verdianijevu pristupu Firentinskom zborniku«. Forum, 15. 401424.

Malić, Dragica. 1999. »Varijante marijinskih molitava u dubrovačkim molitvenicima i tzv. Marulićevu molitveniku«. Filologija, 32: 107-143.

Malić, Dragica. 2003. »Neobjavljeni dijelovi takozvanog Marulićeva molitvenika«. Rasprave Instituta za hrvatski jezik i jezikoslovlje, 29. 181-209.

Malić, Dragica. 2004. »Zašto tzv. Marulićev molitvenik nije Marulićev?« Colloquia Maruliana, 13. 5-19.

Malić, Dragica. 2006. »Neke razlike među poznatim rukopisima Marulićeva Naslidovan 'ja«. Colloquia Maruliana, 15. 27-61.

Malić, Dragica. 2009. »Marulić i crkvenoslavenska tradicija«. Colloquia Maruliana, 18. 161-209.

Malić, Dragica. 2010. »Zašto Margarita nije Marulićeva?« Colloquia Maruliana, 19. 185221.

Malić, Dragica. 2011. »Odjeci najstarije hrvatske pjesmarice u Marulićevim stihovima«. Colloquia Maruliana, 20. 75-105.

Maretić, Tomo. 1889. Istorija hrvatskoga pravopisa latinskijem slovima. Zagreb: JAZU.

Margetić, Lujo \& Bratislav Lučin, prir. 2005. »Marulićeva oporuka«. Colloquia Maruliana, 15. 5-71.

Marulić, Marko. 1869. Pjesme Marka Marulića. Skupio Ivan Kukuljević Sakcinski. Prir. Vatroslav Jagić. Zagreb: JAZU.

Marulić, Marko. 1954. Davidias. Prir. Josip Badalić. Zagreb: JAZU.

Marulić, Marko. 1986a. 1987. 1987 [1507]. Institucija I, II, III. Priredio i preveo Branimir Glavičić. Split: Književni krug.

Marulić, Marko. 1986b. Drame. Prir. S. P. Novak i M. Klenovar. Zagreb: Hrvatsko društvo kazališnih kritičara i teatrologa.

Marulić, Marko. 1989a. Od naslidovan’ja Isukarstova. Prir. Zvonimir Kulundžić i Julije Derossi. Zadar \& Duvno: Nadbiskupija Zadarska \& Sveta baština.

Marulić, Marko. 1989b. Od naslidovan’ja Isukarstova. Prir. Milan Moguš. Split: Književni krug.

Marulić, Marko. 1989c. O poniznosti i slavi Kristovoj. Prir. B. Glavičić. Split: Književni krug.

Marulić, Marko. 1991. Starozavjetne ličnosti. Prir. B. Glavičić. Split: Književni krug.

Marulić, Marko. 1992. Latinska manja djela, I. Prir. B. Glavičić. Split: Književni krug. 
Marulić, Marko. 1993. Pisni razlike. Prir. Josip Vončina. Split: Književni krug.

Marulić, Marko. 1994. Dijaloški i dramski tekstovi. Prir. Nikica Kolumbić. Split: Književni krug.

Marulić, Marko. 1998. 1998. 2000. Marci Maruli, Repertorium I, II, III. Prir. Branimir Glavičić. Split: Književni krug.

Marulić, Marko. 2005. Latinski stihovi. Prir. Bratislav Lučin i Darko Novaković. Split: Književni krug.

Marulić, Marko. 2011. Latinska manja djela II. Prir. Vedran Gligo, Veljko Gortan, Neven Jovanović, Darko Novaković i Vlado Rezar. Split: Književni krug.

Milčetić, Ivan. 1912. »Dr. Julije Bajamonti i njegova djela«. Rad JAZU, 192. Zagreb: JAZU.

Milošević, Miloš. 1992. „Sedam nepoznatih pisama Marka Marulića«. Colloquia Maruliana, 1. 5-56.

Mladenović, Aleksandar. 1959. „Grafija i jezik dalmatinskih čakavskih rukopisa u Arhivu Jugoslavenske akademije«. Godišnjak Filozofskog fakulteta u Novom Sadu, 4. 117150.

Moguš, Milan. 1976. »Je li Marulić autor Firentinskog zbornika?« Radovi Zavoda za slavensku filologiju, 16. 45-51.

Morović, Hrvoje. 1971. »Marulićev prijevod glasovitog srednjovjekovnog djela De imitatione Christi«. Čakavska rič, 1. 79-115.

Morović, Hrvoje. 1972. »Marulićev prijevod glasovitog srednjovjekovnog djela De imitatione Christi«. Čakavska rič, 2. 155-193.

Morović, Hrvoje. 1984. Izbor iz djela. Split: Splitski književni krug.

Muljačić, Žarko. 1995. »Leksičke bilješke uz Cvitje«. Čakavska rič, 23. 97-111.

Novaković, Darko, ed. 1994. »Novi Marulić: Vita divi Hieronymi (British Library Ms. Add. 18.029)«. Colloquia Maruliana, 3. 5-66.

Novaković, Darko. 1997. „Dva nepoznata Marulićeva rukopisa u Velikoj Britaniji: MS. Add. A. 25 u oxfordskoj Bodleiani i Hunter 334 u Sveučilišnoj knjižnici u Glasgowu«. Colloquia Maruliana, 6. 5-80.

Palameta, Miroslav. 2017. Patristička egzegeza i Marulićeva Davidijada. Split: Književni krug \& Filozofski fakultet.

Pandžić, Zvonko. 1999. „Einleitung«. In: Patricius, Franciscus. 1999 [1583]. Discussiones Peripateticae. Hrsg. von Z. Pandžić. Köln: Böhlau. V-XXXVI.

Pandžić, Zvonko. 2009. Nepoznata proza Marka Marulića. Zagreb: Tusculanae editiones.

Pandžić, Zvonko. 2013. »Marulić - prvi hrvatski teoretičar književnosti«. Vijenac, 505 (11. 7. 2013.).

Pandžić, Zvonko. 2019a. ")Mlin, žito, brašno i mekinjeく. Accademia della Crusca i povijesna arhitektura hrvatskoga jezika«. Vinicije B. Lupis i Branko Matulić, prir. Verba volant, scripta manent. Zbornik u čast akademika Stjepana Krasića O.P. Sveučilište u Splitu. 865-920.

Pandžić, Zvonko. 2019b. »Priča o Bibliji Marka Marulića«. Vijenac, 653 (14. 3. 2019.). 16-17. 
Parenti, Giovanni. 1978. »Una testimonianza parziale della \forma crinito $<$ del $>$ Urania nel Ms. Magliabechiano VII.1183«. Rinascimento, 18. 271-283.

Parlov, Mladen. 2002. »O Marulićevu autorstva djela Život sv. Ivana Karstitelja«. Colloquia Maruliana, 11. 443-456.

Pelc, Milan. 2006. »Podrijetlo drvoreza Marulićeve Judite (1521-1523)«. Mogućnosti, 53. $1-12$.

Posset, Franz. 2013. Marcus Marulus and the Biblia Latina of 1489. An Approach to his Biblical Hermeneutics. Köln: Böhlau.

Posset, Franz. 2018. »What do Marko Marulić and Martin Luther have in common? « Opera Dei revelare honorificum est. Zbornik radova u čast Baziliju Pandžiću. Mostar-Grude: Filozofski fakultet. 159-182.

Pšihistal, Ružica. 2018. „Marulićeva Judita, kurikul i kanon u ruševinama“. U: U jezik uronjeni. Zbornik posvećen Ireni Vodopiji. Dubravka Smajić, Irena Krumes, Nina Mance, ur. Osijek: Fakultet za odgojene i obrazovne znanosti Sveučilišta Josipa Jurja Strossmayera u Osijeku, 353-371.

Rehlein, Malte et al. eds. 2009. Kodikologie und Paläographie im digitalen Zeitalter. Norderstedt: BoD.

Šimić, Marinka. 2014. Akademijin brevijar. HAZU III c 12. Zagreb: Staroslavenski institut.

Štrkalj Despot, Kristina. 2011. „Osorsko-hrvatska pjesmarica. Popis sastavnica, postanje, jezik«. Colloquia Maruliana, 20. 31-73.

Štrkalj Despot, Kristina, ed. 2016. Osorsko-hvarska pjesmarica. Zagreb: IHJJ.

Švelec, Franjo. 1963. »Autor dvanaesteračke legende o svetom Jeronimu«. Zbornik u čast Stjepana Ivšića. Zagreb: Hrvatsko filološko društvo. 353-362.

Tomasović, Mirko. 1999. Marko Marulić Marul. Zagreb \& Split: Erazmus naklada \& Marulianum.

Verdiani, Carlo. 1953. »Il Salterio Laurenziano-Voliniense. Codice paleoslavo del 1384«. Ricerche Slavistiche, 3. 1-29.

Verdiani, Carlo. 1957. »Il codice Dalmatico-Laurenziano. Ms. croato dei primi decenni del XVI secolo«. Ricerche Slavistiche, 5. 29-141.

Verdiani, Carlo. 1973. O Marulićevu autorstvu Firentinskoga hrvatskog zbornika iz XV stoljeća. Split: Književni krug.

Vučković, Josip. 2013. »Mnogo lipo govorenje svarhu muke Gospodina Isukarsta slatkoga. Pasionski prozni tekst iz Firentinskoga zbornika«. Slovo, 63. 159-196.

Young, John \& Henderson Aitken. 1908. A Catalogue of the Manuscripts in the Library of the Hunterian Museum in the University of Glasgow. Glasgow: James Maclehose and Sons.

Zaninović, Antonin. 1950. »Marulićeve knjige u Dominikanskoj knjižnici u Splitu«. Zbornik u proslavu petstogodišnjice rođenja Marka Marulića 1450-1950. Zagreb: JAZU. 301-310. 


\title{
MAGNIFICAT ANIMA MEA DOMINUM
}

KROATISCHE NACHDICHTUNG UND EXEGESE VON

MARKO MARULIĆ

\section{Fazit}

\author{
Zvonko Pandžić \\ Wirtschaftsgymnasium Tauberbischofsheim \\ Dr.-Ulrich-Straße 1 \\ 97941 Tauberbischofsheim \\ Deutschland \\ zvonko-pandzic@t-online.de
}

Mit dem vorliegenden Beitrag setzt der Verfasser seine Forschungen (2009) zu verlorenen Handschriften kroatischer Prosa fort, die Marko Marulić (1450-1524) für seine Schwester Bira (Elvira, Vera) zusammengestellt hat und deren Existenz von dessen Zeitgenossen sicher bezeugt wird. Analysiert wurde hier die Exegese des Magnificat aus dem Florentiner Sammelband (Ashb. 1582) dergestalt, dass der Verfasser den Text der kroatischen handschriftlichen Exegese aus Florenz und den entsprechenden gedruckten Text der lateinischen Bibel (1489) aus der Privatbibliothek Marko Marulićs, in dem dieser eigenhändig Randnotizen und Markierungen angebracht hat, vergleichend gelesen hat. Es ist gesichert, dass der Autor der Exegese, deren Handschrift aus Split stammt, die Kommentare des Nikolaus von Lyra gerade aus jener lateinischen Bibel teilweise übernimmt, übersetzt und paraphrasiert, die er besessen und die Marulić glossiert hat. Da kein einziger Schreiber seiner Zeit aus Split die genannte Bibel besessen, geschweige denn glossiert hat, wird daraus der Schluss gezogen, dass (auch) deshalb Marulić der Autor der genannten Exegese und des Florentiner Sammelbandes bis f. 120 ist. Damit wird endgültig die lange bestrittene These Carlo Verdianis (1957) verifiziert, nach der die Autorschaft dieses Sammelbandes Marulić zugeschrieben wurde. Von dieser Verifikation betroffen ist auch eine ganze Reihe weiterer kroatischen Prosa-Kodizes, die ebenfalls Marulić zugeschrieben werden dürfen. Mit Hinblick auf den baldigen 500. Jahrestag des Todes des Vaters der kroatischen Literatur (1524) stellen die Funde des Verfassers die kroatische Philologie vor große editorische Herausforderungen.

Schlüsselbegriffe: Marko Marulić, Exegese, Magnificat, Florentiner Sammelband (Ashb. 1582), Attribuierung eines anonymen Kodex 


\title{
MAGNIFICAT ANIMA MEA DOMINUM CROATIAN REWORKING AND EXEGESIS \\ BY MARKO MARULIĆ
}

\begin{abstract}
Zvonko PANDŽıĆ

Wirtschaftsgymnasium Tauberbischofsheim

Dr.-Ulrich-Straße 1

97941 Tauberbischofsheim

Deutschland

zvonko-pandzic@t-online.de
\end{abstract}

In this paper, the author continues his research started in 2009 on the lost Croatian prose texts compiled by Marko Marulić (1450-1524) for his sister Bira (Elvira, Vera), authored by himself and his close friend Frane Božićević. The author analyses the exegesis of Magnificat from Firentinski zbornik [Florentine Miscellany Ms. Ashb. 1582] by comparing this handwritten manuscript preserved in Florence to the corresponding printed text of the Latin Bible (1489) from Marko Marulićs private library, with Marulić's own notes and miniature drawings. It is deducted that the author of the exegesis - the manuscript originates from Split - partly takes over, translates, and paraphrases the commentaries of Nicholas of Lyra, published in parallel - verse by verse - with the Latin text from the Bible, owned and annotated by Marulić. Since no other writer from Split of his time possessed nor, furthermore, annotated the Bible, it was concluded that Marulić, along with other copious evidence and indications, is the author of the said exegesis and of Firentinski zbornik. This at last confirms Carlo Verdiani's (1957) long-contested thesis, attributing the authorship of the compilation of texts to Marulić. This verification has affected a whole range of Croatian prose manuscripts, which should also be attributed to Marko Marulić. In view of the fast-approaching 500th anniversary of the father of Croatian literature's death (1524-2024), the author's findings place greater text-critical and editorial challenges on Croatian philology.

Keywords: Marko Marulić, exegesis, Magnificat, Firentinski zbornik [Florentine Miscellany Ms. Ashb. 1582], attribution of anonymous Croatian codices 